\title{
Wrestling for our Humanity: An Examination of College Degree Choice Processes used by Freshmen and Sophomores at West Virginia University
}

Cyprien N. N. Lokko

West Virginia University

Follow this and additional works at: https://researchrepository.wvu.edu/etd

\section{Recommended Citation}

Lokko, Cyprien N. N., "Wrestling for our Humanity: An Examination of College Degree Choice Processes used by Freshmen and Sophomores at West Virginia University" (2011). Graduate Theses, Dissertations, and Problem Reports. 3544.

https://researchrepository.wvu.edu/etd/3544

This Dissertation is protected by copyright and/or related rights. It has been brought to you by the The Research Repository @ WVU with permission from the rights-holder(s). You are free to use this Dissertation in any way that is permitted by the copyright and related rights legislation that applies to your use. For other uses you must obtain permission from the rights-holder(s) directly, unless additional rights are indicated by a Creative Commons license in the record and/ or on the work itself. This Dissertation has been accepted for inclusion in WVU Graduate Theses, Dissertations, and Problem Reports collection by an authorized administrator of The Research Repository @ WVU.

For more information, please contact researchrepository@mail.wvu.edu. 
Wrestling for our Humanity: An Examination of College Degree Choice Processes used by Freshmen and Sophomores at West Virginia University.

\author{
Cyprien N.N. Lokko
}
Dissertation submitted to the College of Human Resources and Education at West Virginia University in partial fulfillment of the requirements
for the degree of
Doctor of Education
in
Curriculum and Instruction

\author{
Approved by \\ Patricia Obenauf, Ed.D., Chair \\ David Callejo Pérez, Ed.D. \\ Sebastian Diaz, Ph.D., JD \\ Osman Alawiye, Ed.D., JD \\ Allison Swan-Dagen, Ph.D.
}

Department of Curriculum and Instruction

Morgantown, West Virginia

2011

Keywords: Financial reward; Economic propensity; Peer and parental influence; College Major

Copyright 2011 Cyprien N.N. Lokko 


\begin{abstract}
Wrestling for our Humanity: An Examination of College Degree

Choice Processes used by Freshmen and Sophomores at West Virginia University.
\end{abstract}

Cyprien N.N. Lokko

This research examined the extent to which future job prospects, peer and parental influence and or intrinsic interest impacted the college major selection processes utilized by freshmen and sophomores. Using a mixed method approach, the researcher interviewed six college recruitment officers, administered surveys to 466 freshmen and sophomores and also conducted a document analysis of college brochures and view books all in a bid to ascertain what combination of factors define the major selection process. Data analysis revealed that economic propensity which translates into projections about future job placement, job advancement and or job security somewhat played a role in the major selection process. Besides economic factors, familial and peer influence played a role in students' prospective major choices though the culminating choice was driven heavily by intrinsic interest. Students tended to be proactive towards meeting their academic commitments while utilizing other support networks. Analysis of interview transcripts confirmed student proclivity for self-direction however, the tendency to settle for majors with proven economic promise was a recurring subject in college recruiter interviews. Interview transcripts also revealed that attendant college overhead costs such as tuition and fees affected student college major choices especially for out of state students. Document analysis also revealed that colleges valued scholarship and intellectual prowess over the promotion of economic promise post-graduation. Given the spiraling nature of factors that define the college major choice process, it is safe to consider a myriad of factors, situations, and or conditions when determining the character and disposition of students with regards to major selection. 


\section{Acknowledgements}

\section{To God be the Glory}

I will want to give thanks to the Almighty God for granting me the grace and the wisdom to see this project through to the end. I will like to dedicate this dissertation to my late mother Beatrice Ablah Lokko, and my father, Mr. C.B. Lokko whose mentorship and nurturing has inspired my academic pursuits up to this point. I will also extend a hand of warm gratitude to Dr Patricia Obenauf and my entire doctoral committee, Dr. Callejo Pérez, Dr. Sebastian Diaz, Dr. Swan Dagen and Dr Osman Alawiye for their specialized judgment, patience and willingness to guide my intellectual thoughts on the plains of research. I will be remiss if I fail to mention my wife and daughter, Sheila and Gabrielle Lokko. They have lived and experienced the emotional pangs that have afflicted me throughout this process. A hand of thanks also goes to my cousin, Dr. Kezia Awadzi who whole heartedly offered a hand of support when my efforts seemed to be waning. I will also like to mention my siblings, Dr. Christine Lokko, Juliana Lokko and Leticia Lokko who have been a force of encouragement in my pursuit of this degree. And to all the participants of this study who contributed in diverse ways in catapulting me onto the summit of this scholarly experience, I am truly grateful and May the Almighty God reward you in multiple ways. 


\section{Table of Contents}

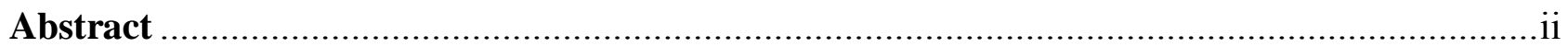

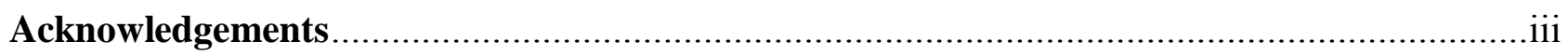

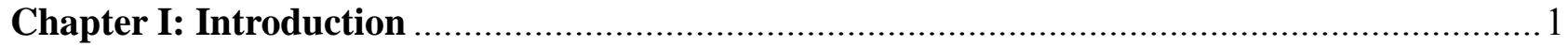

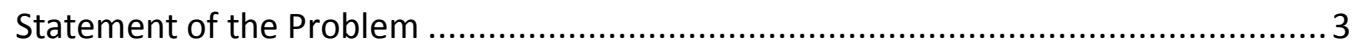

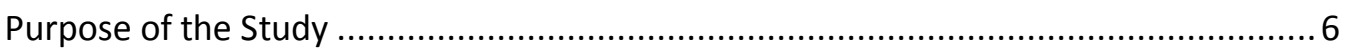

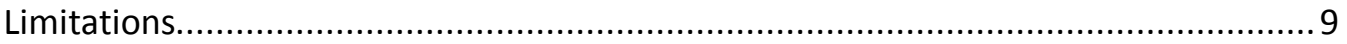

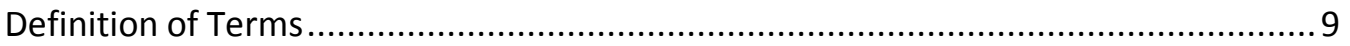

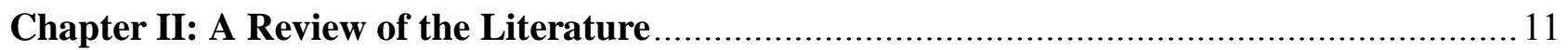

History, Politics and Access to Higher Education ................................................. 11

Understanding the College Major Choice Process ................................................. 21

Attendant Effects of Peer Influence during the College Major Selection Process .......... 26

Attendant Effects of Parental Influence during the College Major Selection Process . 27

Chapter III - Methodology

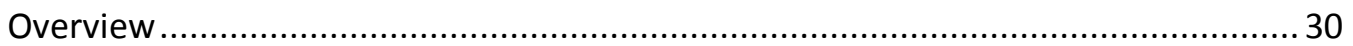

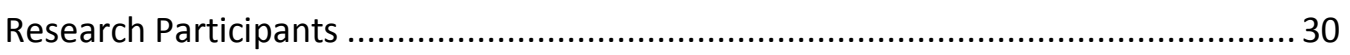

Freshmen and Sophomore Participants ............................................................. 30

Educational Background of Respondents' Parents or Guardians................................ 33

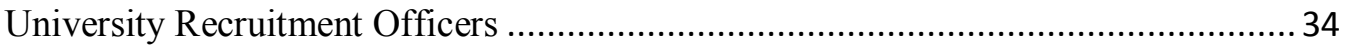

Protection of Human Subjects .................................................................. 35

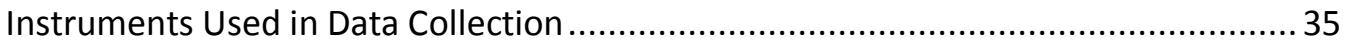

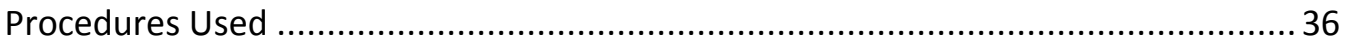

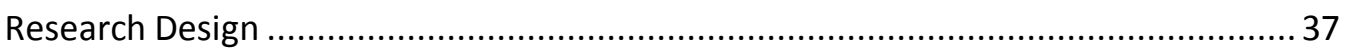

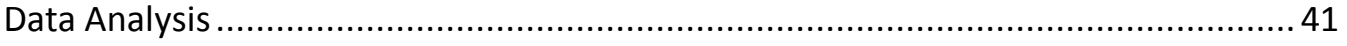

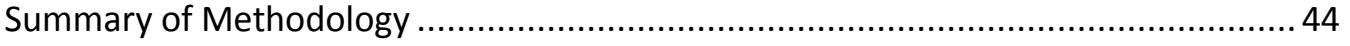

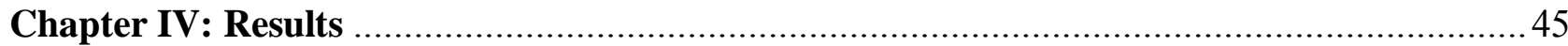

Results for Research Question One .............................................................. 46

Results for Research Question Two .................................................................. 53

Results for Research Question Three ............................................................. 55 


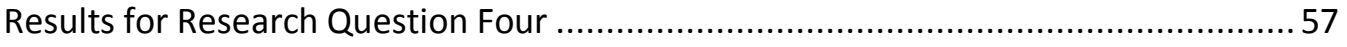

A Detailed Account of Recruitment Officer Interviews .........................................62 62

The Mission and Character of a Successful Recruiter............................................... 64

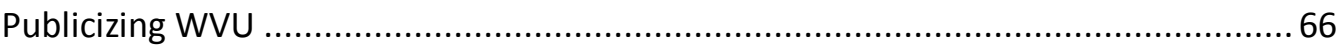

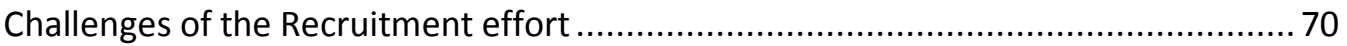

Reminiscences about College Major choice - the Recruiter Perspective.................... 72

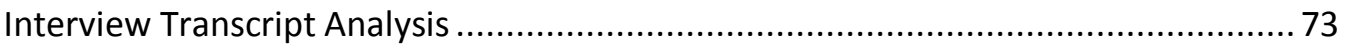

A Detailed Document Analysis of College Brochures ............................................. 75

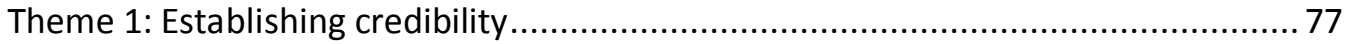

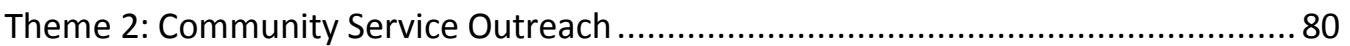

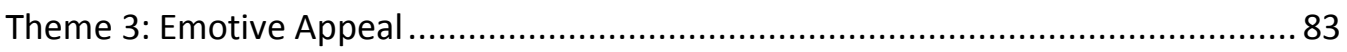

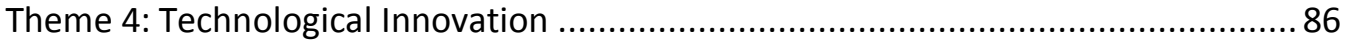

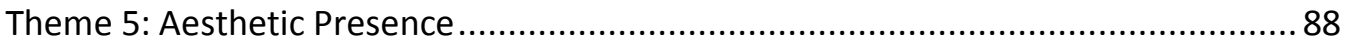

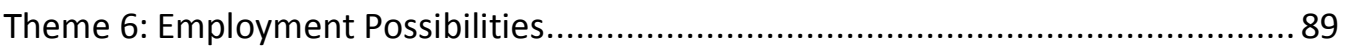

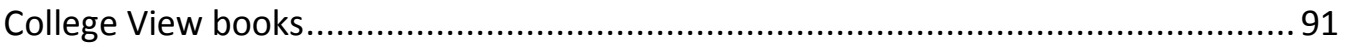

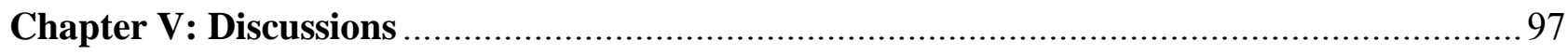

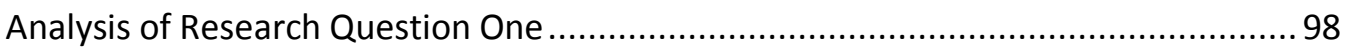

Analysis for Research Question Two ............................................................... 101

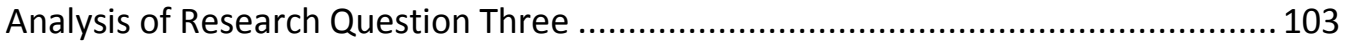

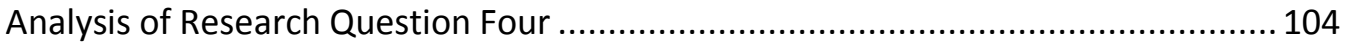

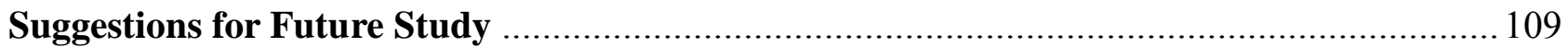

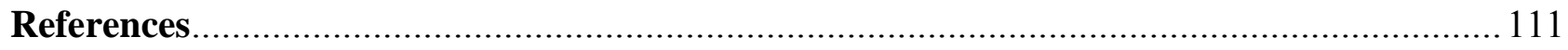

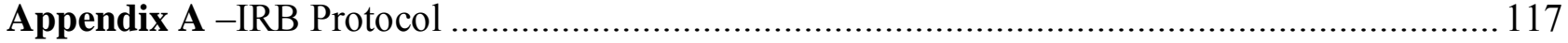

Appendix B - CITI Training Certificate .................................................................... 118

Appendix C - Cover Letter sent to Students and Recruitment Officers................................. 119

Appendix D-Survey questions for Freshmen and Sophomores........................................ 120

Appendix E - Interview Questions for WVU Recruitment officers. .................................... 126

Appendix F -Interview Transcripts for Recruitment Officers ......................................... 127

Appendix G - Quantitative Data for Freshmen and Sophomore Surveys .............................. 145 


\section{Tables}

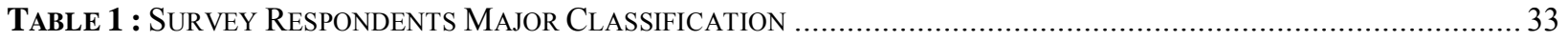

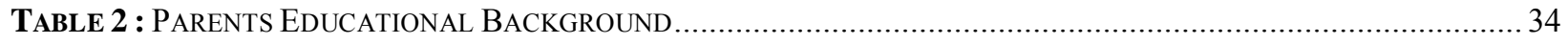

TABLE 3 : Research Question And Matching Research InSTRUment TABLE............................................ 37

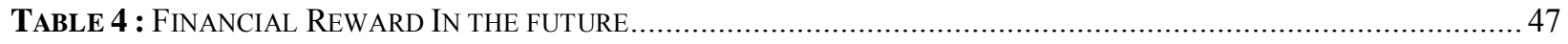

TABLE 5 : ProsPectS OF AdVANCEMENT IN THE JOB MARKET .................................................................. 48

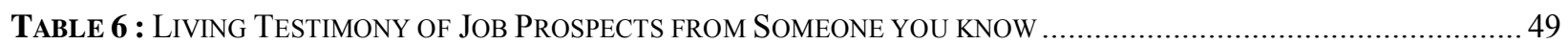

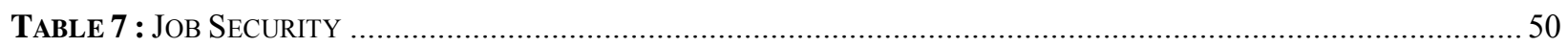

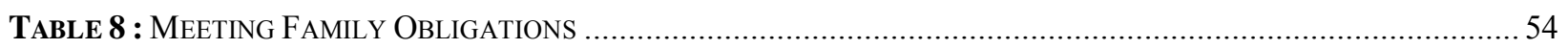

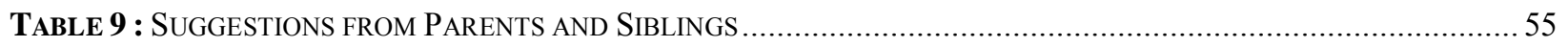

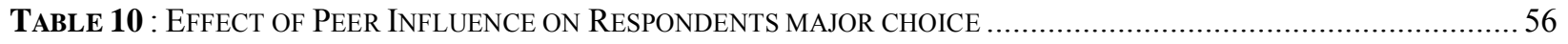

TABLE 11 : STUDENT PASSION FOR THE INTENDED MAJOR ..................................................................... 59

TABle 12 : Arriving at Major Choice through Personal ResearCH........................................................60

TABLE 13 : ReSEARCH INTO THE LONG AND SHORT TERM BENEFITS OF MAJOR ..............................................61

\section{Figures}

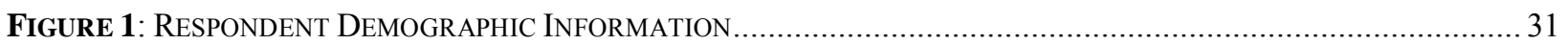

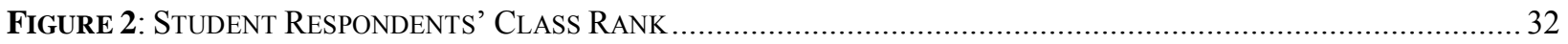

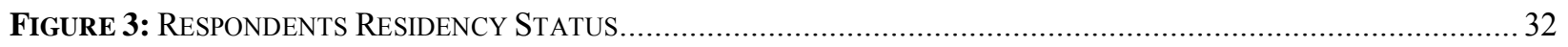

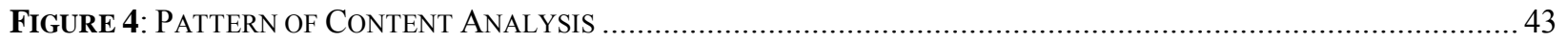




\section{Chapter I: Introduction}

Schools play an eclectic and dynamic role in the development of the social, political and economic structures of every society. They mirror the dispositions of their communities by providing the youth with the necessary skills needed to actively participate in the body politic of their societies. Overtime however, the schools' mission changes, leading to a reinvention of educational philosophies as a result of socioeconomic and political transformations that take place in the community. Schools, thus partner, with their local communities by acting as "embryonic" societies, which nurture the "immature" by availing them to the workings of the larger body politic (Dewey, 1944). The treatise on the schools' changing mission gains relevance in this research because schools serve as a platform for grooming and preparing the "immature" to effectively contribute to societal development. It is, therefore, prudent to retrace our history in

order to understand how the philosophies and pedagogical structures of American education have influenced student perceptions of the educational enterprise over time.

Over the years, the tempo of American educational philosophies has been controlled by different political, economic or historical events such as the promulgation of the Olde Deluder Act (1647), the GI Bill (1944), the Russian Launch of Sputnik (1957), and the bombing of the World Trade Center (2001). These notable epochs in American history have either directly or inadvertently caused a reinvention of American educational philosophies in one way or another. Educational policies along the lines of architecture, pedagogy, educational equity and educational access have been doctored by the above-mentioned historical events and more. In more recent times for instance, the fight to improve educational standards and ensure equity for all students led to the promulgation of legislation such as the No Child Left behind Act of 2001 . Though such legislations are normally saddled with good intentions, the helplessness reliance on 
mechanized curriculums to meet performance benchmarks has inadvertently led to the glorification of rote learning all in the name of creating a level field of educational opportunity for all students.

In recent times, the dangers of global warming and the attendant effects suffered from an ailing economy have colored school curricula as well. A good instance is the introduction of teaching pedagogies attuned with environmental issues. On a more dismal note, budget cuts have led to the elimination of music and physical education classes in a bid to balance school budgets. The import of this treatise on changing school philosophies against the backdrop of socio economic change is relevant to this research because it affects all educational institutions' including colleges and universities, which happen to be where participants for this research were recruited. As educational philosophies change as a result of economic, social or political factors, perceptions about the "schooling experience" are bound to change for both educational institutions and students especially since schools serve as feeding mills for industry. To help perpetuate the schools' role in this partnership with industry, hidden curriculum in the form of posters, college yearbooks, and brochures render the benefits of pursuing an education in economic terms. What makes this phenomenon fatalistic is that schools unconsciously encourage straightjacket curricula that perpetuate the status quo and obliterate the thought of intellectual freedom. The schools' pedagogy and or praxis according to Tyler (1949) is born out of a carefully calculated thought process which takes into consideration a forensic assessment of learner needs based on the community's needs. The assessment of the community's pedagogical needs is followed by a methodical arrangement of learning experiences aimed at facilitating learning skills which address that lack in the community. Evaluation instruments are then administered to ascertain a learner's mastery of content. 
The school's effort in regulating the direction of societal development is thus pivotal and as such very relevant to the quest to reverse the current straightjacket mentality that enervates independent and innovative thinking. Our educational structures according to Freire (1973) are devoid of praxis meaning that teaching pedagogy and the educational enterprise alienates school curriculum from real life experiences instead of forging praxis that promotes action and reflection. This condition creates a fertile ground for necrophilia as students assume a learned helplessness, which is the byproduct of mechanistic educational philosophies (Freire, 1973). Perhaps the source of this oppression can be traced to the door of capitalist ideologies eating at the heart of American educational philosophies. The inextricable bind between the capitalist market culture and our educational institutions sets in motion tailor measured teaching pedagogies responsive to the demands of industry. Students are thus led to unconsciously believe that education is primarily meant to be a springboard to economic advancement.

\section{Statement of the Problem}

Overtime teaching pedagogies in schools have fallen prey to the commercialization of the worth of knowledge. The looming presence of modernist and industrialist ideologies that favor a factory model of education has tainted the true notion of a liberating educational experience. Rigid curriculums and attendant teaching pedagogy born out of a culture of standardized testing has led to the valuing of letter grades at the expense of sensitivity to the benefits of intellectual fulfillment (Postman, 1995). This current mentality is fed by an unconscious idolization of economic success in our schools. Students are indoctrinated into thinking at an early age that learning is transient (emphasis on grades) and that the ability to ride the tide of economic success is the hallmark of an education. 
Educational stakeholders fail to look beyond standardized testing indicators when developing policy to facilitate pedagogical delivery. All students are careened into academic capability paradigms by virtue of perceived competence on a battery of tests. This culture of patronizing selective pedagogy and delivery ingrains in students a "value- driven" mentality which guides the academic decisions they make. Since some learning experiences are tagged for high stakes decision-making, there is an unspoken assumption that some subject areas are more relevant than others (Eisner, 1979).

According to Kozol (1991), the deficiency in intellectual development is a frequent phenomenon in economically deprived schools. The lack of facilities and the economic challenges prevalent in such environments contributes to a lag in maintaining high teaching standards as good teachers and administrators shy away as a result of economic and structural impoverishment. In recent times however, the pervasiveness of economic hardships in federal, state and local circles has extended the arm of efficiency and budget maximization to all spheres of the American schooling enterprise. Economic hiccups have led to the sidelining of liberal arts programs albeit unconsciously, in the hopes of promoting disciplines which connote economic promise. This in no doubt gives life to industrialist ideologies that promote a nonchalant attitude towards factory styled educational agendas that are not only intellectually abrasive but insulting to the human condition. The penchant for industrialist minded pedagogies has a long history in curriculum development. In the early 1900s, Franklin Bobbit pioneered the transfer of scientific management techniques into curriculum building in the The Curriculum (1918). Determined to inject efficiency into the curriculum, Bobbitt (1918) advocated for educational curriculum that actively prepared students to aptly meet the needs of the society. This was to be achieved through the use of directed and undirected experiences (Pinar, Reynolds, Slattery \& Taubman, 
2004). Even though curriculum development theories have evolved progressively since the 1900s there is still a patronage of scientific and industrialist minded pedagogy and philosophies because they afford school administrators an easy way to assess and group students into ability paradigms (Eisner, 1979). From the industry standpoint, the benefit of enjoying a labor pool schooled using a prescriptive vocational curriculum is enticing because of the economic possibilities it presents. Illich (1970) argues that educational experiences that place premium on the economic worth of diplomas, deny students the intellectual enlightenment needed to examine the socio- political as well as cultural underpinnings of society.

The schooling experiences in our middle and high schools and most notably our universities today reverberate in Illich's accusation. Standardized testing has led to the development of myopic curriculum in secondary institutions while some members of the professorate in tertiary institutions place emphasis on grant acquisition, tenure, with little interest in undergraduate teaching (Hutchins, 2003). The argument that is made here is that the quality of our current educational experiences in our institutions of learning particularly the college and university settings is waning. Current educational philosophies are creating a fertile ground for cut and dry educational experiences that place students into prepackaged educational aspirations with no concerted involvement on their part. There seems to be a fixation on economic prospects in terms of jobs or remuneration post-graduation. Countless numbers of students select classes by virtue of a professor's grading scale and the easiness of a course. Others drop out of classes when they fall a letter grade or face any difficulty with course content. In such situations there is a tendency among some students to scout for easier sections of the same course. When no other remedy exists in terms of an "easy course", a change of major or even school (summer school) is considered in instances where the student is bent on getting into that major. 
The current research attempted to study among other things, the phenomenon of economic utility and how it impacts college major choices of freshmen and sophomores. College education is now more of a business investment, requiring the investor (student) to make impressive returns. For this reason, personal preferences and or a passion for any particular major is no longer a constant. If the student's interests and his or her major choice mesh then the he or she gets the best of both worlds. Though the phenomenon of economic utility has a heavy influence on student major selection processes, it is imperative to note that a student's social and cultural background and or a belief in themselves as having the knack to succeed (self-efficacy) is also pivotal in the major selection process besides the lure of economic utility which this paper sought to examine (Bourdieu, 1990). The current study examined how the following factors: economic utility (financial rewards post-graduation), peer and parental influence and intrinsic interest affected the major selection process among freshmen and sophomores advised at West Virginia University’s Undergraduate Advising Services Center.

\section{Purpose of the Study}

The pangs of industrialism and the current low tide of economic advancement in recent times have colored the perceptions of students with regards to what constitutes an educational experience. The looming presence of unemployment as a result of the current economic downturn has resulted in the patronage of college majors that purportedly hold economic promise such as Business, Health Sciences and Engineering while liberal arts majors experience a shortfall in student enrollment. The tainting of the college education experience with the promise of economic fluidity is in part caused by how colleges and universities value or perceive college majors. 
Some majors have high promise for winning grant awards while some are awarded next to nothing (Zemsky, Wegner \& William, 2005). This creates the assumption that some majors have more clout than others and students imbibe such perceptions.

Though passion for a discipline or major for that matter can and should be the undercurrent guiding college major choice, there is more often than not, a recursive resort to the economic value and job placement prospects of a supposed major. It must be mentioned though that there are also countless number of students who take classes as a result of an intrinsic passion for the subject as opposed to an affliction with good grades. However, the allure for good grades, which is an offshoot from the pressures of economic utility, is now common feature noticed among students during academic advisement. Students ironically find themselves on a conveyor belt of economic utility that threatens to stifle the intellectual importance of majors, which have no ready economic promise. Economic utility thus steals the very essence of the learning experience by fronting a curtain of economic possibilities (e.g., jobs, good remuneration) at the expense of intellectual fulfillment (Zemsky et al., 2005).

This current research sought to examine whether the culture of learned helplessness brought upon us as a result of the heavy hand of market centered economies in any way impacts the major selection process by freshmen and sophomores at West Virginia University. Our educational systems promote content mastery for grade advancement while rewarding student efforts with diplomas. Students thus make the weighting of a college major's economic prospects the centerpiece of their educational experiences. The pressures of economic success thus punctuate the collegiate experience right from the search for colleges, declaration of college majors right through to the award of the college diploma. 
As students negotiate these different landmarks in their academic life they are guided by the economic worth of the educational experience.

This research examined how variables such as "economic utility", "peer and parental influence" and last but not the least, "intrinsic interest" influence the college major selection process among freshmen and sophomores advised at West Virginia University's Undergraduate Advising Services Center. The research was guided by the following questions:

\section{Research Questions}

R.Q.1) How does the prospect of financially rewarding jobs influence the major selection process by freshmen and sophomores at West Virginia University?

R.Q.2) To what extent does a student's family influence the college major choice process?

R.Q. 3) To what extent does a student's friends or peers influence the college major choice process?

R.Q.4) To what extent does a student's interest in a major affect the college major selection process?

These research questions helped in examining the role economic utility, family and peer support systems, and intrinsic interest play in the major selection process among freshmen and sophomores at West Virginia University. It must be mentioned that the choice of a college setting as a point of reference for examining the influence of economic utility on educational philosophies in no way rules out the effect of the phenomenon in our elementary, middle and high schools. The choice of a college setting for this research is important for one because colleges are symbolically an entry point to the work force. 
The collegiate experience also signifies a rite of passage, which weans the youth of their dependence on their guardians. From that point onward, the individual is expected to be innovative and above all critical in thought.

\section{Limitations}

The current research examined the college major selection processes employed by freshmen and sophomores advised at West Virginia University's Undergraduate Advising Services Center. This population excluded other freshmen and sophomores not advised in the undergraduate advising center as well as juniors and seniors. This renders the research results inconclusive since other groups of freshmen and sophomores advised in the departmental settings may hold other viewpoints. Again the results from the current study pertain only to students and staff in West Virginia University and as such the conclusions may not be "generalizable" to other university or college settings. To comfortably generalize the conclusions drawn from the current study, there is a need to replicate the study in other college and university settings preferably in state or out of state. The next segment enumerates a list of terms used in the current research.

\section{Definition of Terms}

Economic Utility: Economic utility as per this research refers to the heavy influence of market economies on educational decision making. It also involves a student's propensity to ascertain economic promise of a supposed major in lieu of intellectual enlightenment when making decisions concerning academic aspirations. This thinking can possibly overshadow student interest, innovation and more so intellectual fulfillment.

Self-Efficacy: Based on Albert Bandura's Social cognitive Theory, self-efficacy refers to an individual's resourcefulness towards meeting an academic goal or need by singlehandedly 
weighing out options, opportunities or potential for any particular major. Emphasis is placed on a "self-driven" initiative to reach an end goal.

Habitus: According to Pierre Bourdieu, habitus refers to a situation whereby the individual agent is influenced by factors, situations or elements, which surround him or her. In the context of this paper, habitus is tied more strongly to how an individual's social, cultural, and political ecologies (for instance, peers and friends) influence his or her thinking and way of life. These experiences may shape the decisions that students make about their college majors.

Critical Theory: Critical theory in part attempts to dig deep into multifaceted issues such as equity, equality and access and how it impacts pedagogy and student opportunities. Its goals are to create an enabling environment for students to succeed while enjoying equal opportunities with regards to educational empowerment and unhindered access to contribute and enjoy the benefits of belonging to the larger body politic.

Sophomore: Sophomore class rank in West Virginia University is determined by a student's credit hours. Any student who has between 29 to 58 credit hours (this can include transfer credits or advanced placement credits) is deemed a sophomore. Most departments will formally admit students with sophomore status at this point if they have the requisite GPA to apply or transfer to their intended program of study.

College Major: This refers to a student's area of study or course designation that determines their career path eventually. The research sought to find out how this process unfolds and what matrix of factors determines a student's eventual choice of a major. 


\section{Overview}

\section{Chapter II: A Review of the Literature}

The review of literature for the current research is divided in three parts. The first part examines the historical, political and economic factors that have shaped higher education over the years. This is followed by a synthesis of literature pertaining to the determinants of the college major choice process. The third section is further broken down into two sub sections which cover a review of literature on peer and parental influence respectively.

\section{History, Politics and Access to Higher Education}

To help in understanding the circumstances that have led to a fixation on the economic potential of the collegiate experience at the expense of harnessing the intellectual worth of the learning experience, it is necessary to revisit the humble beginnings of the institution of higher learning with a view to understand its present demeanor. Prior to the war of $1812^{1}$, higher education in the United States was theological in nature. Pulliam (1991) asserts that the teaching of subjects like mathematics, classics and theology was to prepare would be clergymen and also to meet the leisure pursuits of the wealthy in society. According to Wilshire (1990), the university's mission at the time was to promote salvation through a fostering of a literate culture among protestant groups.

\footnotetext{
${ }^{1}$ The war of 1812 was triggered by the United States resolve to fight British imperialist rule. It spanned a period of two years (1812- 1815). The British government deemed the United States as a colony and so it placed certain restrictions on its day-to-day governance. The war was therefore an attempt to stage a
} 
It is therefore not surprising that a good number of clergymen dabbled in the affairs of the university, leading to the establishment of Harvard College in 1636 and the University of South Carolina in 1879 by the Methodists.

Wilshire (1990) opines that up until the 19th century, institutions of higher learning were "medieval" in nature with three distinct faculties namely: law, medicine and theology. The intrusion of circular interests coincided with an outburst of a new middle class, which redefined the university's mission. What this meant then was that the narrow focused curriculum had to expand to meet not only the changing clientele of the old college but also to adapt to the influence science and technology was beginning to have on the economy. Wilshire (1990) argues that the remnants of that "old colonial college was entirely inadequate, picayune and shoddy" (p.62). The diversification of the college's clientele and the gradual emergence of a secular mission also occasioned the segmentation of disciplines in the university in the 19th century. This period was characterized by a proliferation of professional organizations and more so a craving for specialization among the disciplines (Wilshire, 1990). The creation of deep craters among different paradigms of specialized knowledge, Kerr (2001) concurs, defined the university in the present age as "a whole series of communities and activities held together by a common name, a common governing board and related purposes" (p.1).

There were some more defining periods in the history of higher learning in America that helped it leap its bounds beyond its medieval culture. On one part was the promulgation of legislations, a notable one being the Land Grant Act established through the Morrill Act of 1862. The increasing influence of science and technology coupled with the nation's growing demand for an expansion of the agricultural sector prompted the need for expertise from the college community. In a bid to encourage American universities to take up the mantle of research and 
uphold a culture of service through the provision of agricultural expertise to local communities, the federal government provided wide acreages of land for the extension of university campuses. This action was taken as a way of encouraging beneficiary universities to engage in research pertaining to agricultural extension services and the participation in local community outreach (Pulliam, 1991). According to Kerr (2001), Land Grant institutions were created to help expand and maintain the industrial and agricultural base in the United States. More importantly, the Land Grant institution redefined the perception of the university as an elitist haven by opening the doors of the university to anyone who had an interest in the pursuit of a college degree.

Nonetheless, the issuance of the GI Bill after World War II also afforded "jobless" soldiers returning from the war an opportunity to walk the hallways of higher education (Zemsky et al., 2005). The burgeoning numbers on university campuses somewhat coincided with a redefinition of the role of the university in society. University faculty in the hard sciences began what will be a long-standing partnership in federal research endeavors. As the numbers grew on university campuses, so did the chores of faculty. University faculties, especially those in the hard sciences were introduced to a new dimension of service as they entered into partnerships with the federal government. Zemsky et al. (2005) state that the partnership between the federal government and university faculty was triggered by a report presented to Franklin D. Roosevelt in 1945 known as "Science: The Endless Frontier." In this report, Vannevar Bush the first presidential science advisor entreated the executive arm of government to invest generously in scientific research. The axis of this research endeavor he recommended should be the American Research University; partly because of the research prowess exhibited by its faculty during the Second World War and more importantly because of their readiness to meet the scientific needs of the nation. This newfound partnership was soon to unveil mixed 
blessings on the research university as these new responsibilities were met with "controversy, celebration and scrutiny..." (Zemsky et al., 2005, p.3).

The social, political and cultural demeanor of the university continued to change more so in the 1960's, an era in which the University's mission had to be redefined in response to changing student demographic patterns and attendant political upheavals for equal representation. Kaplan (1983) writes that the 1960 s were characterized by an "extraordinary openness" (p.8). The period saw the growth of federal student aid and a proliferation of community colleges, which in turn triggered access along the lines of "diversity and innovation" (p.8). More importantly, it redefined the university curriculum structure as electives, new courses and individualization took the place of the essentialist rigidity that previously characterized university curriculum.

Hall and Kelves (1983) elaborating on the conditions in the 1960s postulate that the events that punctuated the era of the 1960s and the aftermath of the Second World War ushered in a diverse body politic in the United States. This diversity hit the corridors of higher education hard, particular undergraduate education, as pockets of groups holding dissenting views namely, feminists and the black power movement wrestled for recognition in the university.

This period saw further involvement of university faculty in research and a relentless beckoning to university departments by businesses for them to mirror the economic, sociopolitical, and cultural underpinnings of the business world. Pressure from the federal government because of federal grants and the discreet preferences expressed by industry (preparing students for the workforce) watered down the quality of undergraduate education. Undergraduate education thus began to sacrifice its intellectual fervor at the expense of a pedagogy, which thrived on "vocational preparation" (Hall \& Kelves, 1983, p.19). 
The modern American university has indeed undergone a radical metamorphosis. The leveling of color barriers in the 1960s (Wilshire, 1990), the involvement of more women (and particularly mature students) on college campuses in the 1980 s and the introduction of credit based programs allowing for flexibility in decision making regarding subject choice and time and duration of a degree have changed higher education. Nevertheless, there is yet a more defining change -- the birth of grants, faculty specialization in subject areas and accreditation procedures and demands. These have tainted the color of the university's mission.

Kerr (2001) argues that overtime colleges and universities have subtly discounted the undergraduate teaching process (p. 49). He levels the blame against federal research endeavors, which have set in motion, a "long-standing depreciation of undergraduate education at large universities" (p.49). Hall and Kelves (1983) reiterate the devastation caused by the emergence of the federal grant and its concomitant research obligations for faculty by expressing concerns about the waning qualities of undergraduate education and its metamorphosis into "vocational preparation" (p.19).

Perhaps the answer to the university's swayed mission lies in what Dune (1999) rightly describes as the emergence of a new economic order. This new economic order now influences what sort of skills are going to be marketable while determining what curriculum is of most worth. Barnet (1994) indicates that "academic competence" is no longer a watchword under the new economic order - as rather "operational competence" is the watchword. Muscatine (1983) suggests that the nature of the present curriculum makes room for rote learning as opposed to lifelong learning. Students are "schooled" into a passiveness that distances them from critical thinking or questioning thereby giving way to the acceptance of a "superficial consumerism" which enervates students during the decision making process (p.105). 
This state of mental stupor provides a fertile ground for "our form of government and essentially our conduct of business" (Muscatine, 1983, p.105).

Zemsky et al. (2005) disagree, saying that colleges and universities are mission centered and remotely concerned about an amassment of wealth. Their goal he opines has to do with maintaining the sanctity of intellectual thought and imparting vistas of knowledge to the citizenry through clientele who are privileged to walk its hallways. However, the college or university faces an affliction suffered upon it by the market. The university according to Zemsky et al. (2005) has been affected by what is known as the three Cs of market affliction that are Competition (clamoring for students, faculty and A - rated athletes), Commodification (the university becoming a degree mill) and Commercialism (intensive marketing of research). The current educational dispensation they argue is masterminded by the promise of economic advancement as the import of a collegiate experience is far removed from the acquisition of intellectual fervor as educational diplomas in of themselves have become "sashes" symbolizing “personal achievement (p.162).

The surging influence of the market on higher education is not unique to only schools, as mentioned in the introduction-- our whole society suffers that inertia engineered by the latter. But as Postman (1996) tell us, the measuring of the worth of any educational experiences using the "metric" of economic utility erodes the efficacy of the educational experience. Friere (1973) deems such an education as limiting and intellectually stultifying. The stunted intellectual experience which Friere (1973) describes is seen as the emphatic author of our fate according to Illich (1970). He further contends that our destinies are held ransom by the emerging phenomenon of economic utility. To help derail the machinery of economic utility, there is a need to encourage students to patronize activities that promote "introspection" so that in the 
future they can effectively negotiate the pathways of reality as opposed to settling for artificially set boundaries of "assumed objectives" (Lamdin,1983, p.75). In this regard, university degree programs have to promote a culture of individuality, availing students to educational experiences which promote lifelong learning. These new learning experience must stress the intellectual import of an educational experience as opposed to possible economic rewards tied to any particular discipline.

Though not exhaustive, an attempt was been made in this section to paint a revealing picture of higher learning in America. It was imperative to trace the canker of materialism afflicting the collegiate experience through the crevices of societal life and more importantly through its "embryonic society", the school (Dewey, 1944). The relevance of the quest to understand the degree choice process therefore stems from a need to have a workforce, which regulates the tempo of the market not vice versa. An authentic education as per Friere's (1973) terms is the practice of freedom because it frees the educator and the educated and saves them from the "twin thralldom of silence and monologue" (p. ix). The market economy and the democratic engine in Freire's (1973) view, adopt a sui generis democracy, which deems the citizenry as suffering an ailment requiring the dispensation of "medicine." This medicine in today's terms will be the market economy, which assumes the position of a "know it all" god. In the limiting society Friere (1973) describes, the notion of good health is defined as "silence and inaction" (p.14). Those who tend to speak against intellectually demeaning ideologies are labeled as subversives riddled with foreign ideologies, which are ostensibly damaging to the societal fabric.

The quest to understand the college degree decision-making process stems from a need to decipher the extent to which market centered educational ideologies have affected students' perceptions of what defines an educational experience. I feel that the influence of the market on 
educational ideologies is eating away at intellectual innovation on the part of students as they try to fit into disciplines not for intrinsic interests but for extrinsic rewards such as economic rewards of a prospective major. This phenomenon I believe is a new kind of oppression, which is driving students away from an authentic education. In Friere's (1973) view, no one can free the oppressed unless the oppressed themselves. There is therefore a dire need to shed some light on the ills of a market driven educational enterprise that threatens to turn the university into a vocational learning outlet, which feeds the labor mills of market-centered economies.

\section{Society's Role in Influencing Student Choice.}

Every society invests heavily in the upbringing of its youth. According to Dewey (1944), the socio-cultural underpinnings, which define the nature and character of our societal beliefs and norms, are transmitted to the young through a calculated didactic simulation of the workings of the democratic society (p.2). These simulations are very different from rote learning as they grant the immature an "ability" to negotiate the pathways of past and present experiences (pp.76, 77).

Such an educational experience sets the stage for an unhindered proliferation of intellectual ideas. Students are therefore equipped with a vernacular, which shields them from a thoughtless conformity to rigid paradigms set forth by society (Giroux, 1988). The development of a critical vernacular, according to Friere (1973) is an art of freedom distinct from our present affliction with capitalism, which is an agent of economic domination. Thus educational experiences which incite innovation by promoting the freedom of the mind humanize the youth by awakening them to the fact that there is an inalienable connection between consciousness and the world or vice versa (Friere, 1973; Dewey, 1944). 
The birth of a living consciousness guarding against the abrasiveness of capitalist tendencies in the classroom has to be experienced by the teacher and the student (Friere, 1973, p.56). In this joint search for meaning, teachers and students alike attempt an understanding and a reinvention of reality. This levitation beyond technical and behaviorist knowledge effectively prepares the student to actively participate in the political, social and cultural ethos of the society. This then sets the stage for a meaningful and engaging simulation of life in the real world. Education then, as per Tyler's (1949) terms, affords the immature (Dewey, 1944) the right mix or combination of experiences aimed at availing them to the structure, disposition and sociocultural structure of the society. For these educational experiences to be authentic, they have to address the question of "human purpose and social vision" (p. 52). In the light of this, education has to gravitate from technicality and evolve into a hermeneutic understanding of what it means to be human. (Shapiro and Purpel, 1998, p.52)

Shapiro (1998) reminds us that present educational philosophies are far from being humanizing. He averts that schools have become "training grounds" for jobs (p.46).This penchant for an efficiency model in American education traces its origins to the era of Taylorism ${ }^{2}$, a period when schools began adopting mechanized approaches to learning in the name of promoting efficiency. Because of this mechanization, academic progress is measured in economic terms using numerical indices. High stakes tests have become centerpieces for evaluating the intellectual worth of students even though such measures blur student's academic capabilities (Eisner, 2001).

\footnotetext{
${ }^{2}$ Taylorism as a theory was introduced in 1911 by Frederick Taylor in his book, "The Principles of scientific management. Built on a theory of time and motion, Taylor's theory called for the injection of efficiency in factories by redefining the employee's work ethic. It was assumed that both employer and employee will benefit from this theory.
} 
In McLaren's (2007) view, schools have become "service institutions whose duty in the new efficiency model is to provide the "requisite labor-power capacities" needed to power the wheels of economic progress. He argues that schools form part of the puzzle of a social division of labor, which thrives on the capitalist premise that human capital is essential if we are to immortalize our conservative market centered lifestyles.

Postman (1996) paints a somewhat cynical picture of what education has become. In a metaphorical rendition of the market-centered economy as a god and education as a worshipper heading to the sacrifice, Postman (1996) delineates our helpless marriage to an industrial model of education. He says school offers the young, a "covenant" which promises economic utility (good jobs) if they remain submissive in the classroom and do well on standardized tests. The patronage of economic utility as a measurement of our intellectual worth has rendered capitalism, as the "metric" used to evaluate ones worth (Apple, 1993). Thus anyone who falls short of the production of knowledge with economic value is subject to unpardonable "moral condemnation" (Apple, 1993, p.5).

The significance of any learning experience should not rest on the economic viability of the fruits of production, as rather, it should unfurl a sense of "societal power", "insight" and an awareness of a limitless possibility to expand one's horizon (Dewey, 1944, p.16). It then follows that the helpless affliction to a vocational styled education, which transcends the school's ranks from the incipient stages of elementary education to the echelons of higher education, needs to be reformed. The schools' task of educating students for industry though not implicitly stated has to be broadened to include and an educational philosophy that imbues in graduates a sense of individual efficacy, innovation and a critical spirit. This new educational philosophy therefore has to be devoid of a fixated quest for just economic remuneration and advancement. 
The attendant rewards of a reformed educational experience sensitive to the intellectual development of students lies in its ability to nurture the youth to understand and appreciate the culture, norms and dispositions of their communities (Dewey, 1944, p.28).

The analysis of our current educational system is not meant to suggest a grim future -- as rather it is intended to trigger a hermeneutic evaluation of what it means to educate or be educated. There is a need to understand where capitalism, intellectuality and innovation cross paths. To keep this treatise on the need for a hermeneutic understanding of education ongoing, I will conclude this segment with what Lamdin (1983) thinks education ought to do to us:

Education must be relevant: it must have implications for the four-fifths of a person's life that is spent outside of formal schooling; it must make clear the connection between history and tomorrow's headlines, between economic theory and the debate in congress over tax credits, between literature and life and death.... (p.71)

\section{Understanding the College Major Choice Process}

Choosing a college major is a complex, stress-laden phase of a student's life, which needs careful planning. The stress and complexity that underscores the process is born out of the longterm repercussions of the final choice. The student either lives to regret the choice or ends up enjoying the benefits of that choice. Most students do not think through the college selection process fully as they "back into" majors without applying cognitive decision- making techniques (Beggs, Bantham \& Taylor ,2008, p:2). The culture of making rushed decisions in the major selection process according to Beggs et al., is better understood by studying the demeanor of 
today's student. The crop of students in colleges today fall under the generation Y classification. These groups of students are overly reliant on parents and guardians for a nod of approval. They want assurance and instant gratification, and are heavily wound up in a culture of technological advancement (Carpenter, 2006).

In a bid to understand what factors or combination of factors play a key role in the major selection process, Berger (1988a) conducted a study which sought to examine how the following factors: students' interest in a major, job characteristics of a chosen major, financial considerations associated with a major, the major's attributes as well as the presence of psycho/ social support systems influence a student's eventual college major choice. The study revealed that students relied heavily on "information search" tools while making college major choices. Besides being proactive in their academic quest, students also mentioned that they considered the economic potential of their prospective majors. Berger (1988a) went on to say that despite the seemingly weak influence economic utility had on student choices, seniors who took the survey expressed an interest in financial rewards of the prospective major. Freshmen and sophomores however concentrated on interests. The college major decision process by students in the Berger (1988a) study was preceded by researching the possibilities and feasibility of choosing a said major. Students signed up for introductory classes in the major or accessed brochures or catalogues so they could make informed decisions. Psychosocial factors such as feedback from friends, parents and or high school teachers earned high points confirming the tendency for generation Y students to look for a nod of approval. After analyzing a combination of "means end" qualitative results and a "conjoint" quantitative analysis, Berger (1988a) reports that interest in the major hovered around the fifty-ninth percentile refuting the notion that money was an overarching motive which guided students' major choices. 
DeMarie and Aloise-Young (2003) confirmed student interest as a determinant of major selection in a study that compared 144 education students and 151 Business majors. They reported that about $98 \%$ of respondents surveyed affirmed that interest played a pivotal role in their eventual major choice. Interest levels were however higher among freshmen in introductory business classes than freshmen in education classes.

Though interest is a centerpiece in the college major choice selection process, the potential for career advancement, prospective job opportunities and the ability to meet the cognitive and academic requirements of the chosen major is worth noting. (Malgwi, Howe \& Burnaby, 2005). Malgwi et al. (2005) argued that gender differences influence college major decision processes to a great extent. In their study on the college major selection process, female subjects tended to care more about mental aptitude (ability to meet the intellectual demands of the major) when considering a major while male subjects were more concerned about career advancement and potential job opportunities. Overall, student interest was deemed an important determinant of the college major choice process across gender lines. Research subjects also mentioned that introductory classes and the skill of teachers who taught accounting classes played a vital role in their decision to pursue a business major. High school counselors, parents or academic counselors on the other hand, were not adjudged as being influential in the major selection process.

Kimweli and Richards (1999) also conducted a study on interest as it pertains to the major selection process but they adopted a somewhat hermeneutic approach to the process. Three hundred and twenty one art majors from three universities were surveyed regarding the following: level of interest in the chosen major, perceptions of a quality of life arising from 
making that major choice as well as aspirations for a future job. Using Erikson's theory of integrated self and Bandura's social learning theories, Kimweli and Richards (1999) concluded that maturity largely determined the level of interest a student had in a major. For juniors and mostly seniors, a passion for the subject defied a lack or a potential for attractive financial reward in the job market. Pursuance of an art major therefore was seen as improving the quality of life in abstract terms. Students who held a philosophical outlook about art saw beyond monetary reward and dwelled more on its power to transform. Kimweli and Richards (1996) pointed out though that the ability to experience abstract intrinsic interests in the discipline often eluded people of low socioeconomic status because economic disparities did not avail them to places or experiences where they could appreciate the arts. This point becomes important not so much because of a deprived artistic experience but because of the inalienable influence our socio - cultural backgrounds have on who we are or become. This idea lends credence to Bourdieu's (1990) theory of habitus ${ }^{3}$, which attaches premium to the propensity of socio - cultural ecologies to influence the individual's sense of direction.

Despite the fact that interest plays a dominant role in the determination of the college major choice process as per the literature, there is also a resort to weigh in on economic considerations during the major selection process. In another study by Berger (1988b) students considered the financial viability of an intended major when making a choice.

\footnotetext{
${ }^{3}$ Habitus as per this paper refers to the propensity for a student's academic choices to be influenced by his or her socio- cultural background. Bourdieu (1990) posits that socio cultural backgrounds strongly influence ones behavior.
} 
After controlling for family background as a possible extraneous variable affecting college major choice, Berger (1988b) concluded that starting salaries and job's prospects were crucial factors in the major selection choice process.

Thomas and Zhang (2005) affirmed that major selection processes are heavily influenced by a consideration for future remuneration. They hypothetically contended that students who pursued majors like business, math, science and the social sciences had the tendency to enjoy "post baccalaureate wage growth" within the first four years (p.449). Majors in education and history, which start with similar remuneration packages, tend to decline comparatively as opposed to the sciences and business fields, which gain momentum financially over time.

Besides being characterized by an elaborate thought process, choosing a college major is a multifaceted process (Montmarquette, Cannings \& Mahseredjian, 1997). Using a sub-sample of the 1979 National Longitudinal Survey of Youth, Montmarquette et al. concluded that the following factors: race, family background, cognitive aptitude, and the level of education of parents and older siblings significantly affect college choice processes. Their study revealed that students who took financial aid loans were more likely to think of the financial viability of a degree than students from rich backgrounds. Along the lines of gender, Montmarquette et al. opined that women were more likely to major in education though a majority of their respondents took a liking for business and science majors because they allegedly held economic promise. Montmarquette et al. further added that the college major choice process starts as early as the high school years when students are involved in decisions regarding which colleges they would want to attend.

A recurring theme from the literature is that interest plays a predominant role in the decision to settle for a particular major. Financial viability of the chosen major is also listed as an 
influencing factor. Mental aptitude also deserves mention as being essential in the major selection process, however only one study (Kimweli and Richards, 1996) mentioned intrinsic qualities with respect to how it affects major selection without alluding to the financial reward for a prospective major. Access and use of information regarding majors did not gain high ratings even in an age where there seems to be an influx of information in every shape and form. Having deciphered how intrinsic interest and economic utility impact college major choices as per the literature, it is prudent to also consider what effects peer influence has on the major selection process if any. The next section examines the role peer influence plays with regards to the major selection process.

\section{Attendant Effects of Peer Influence during the College Major Selection Process}

Peer influence according to the Coleman report of 1966 has an inalienable effect on student achievement outcomes. The type of groups or peers students associate with in the elementary and secondary school setting influences the possibility of pursuing a college education or advancing a particular academic ambition (McDill, Coleman, 1965).

In a study determining specialization selection behavior among 47,755 medical school students Arcidiacono and Nicholson (2005) state that medical students aspiring to get in to specialty practice and to some extent those gearing up for general practice benefitted from peer input in terms of academic decision making. This was more so noticeable among high performing female students. No significant effects were realized with regards to peer influence effects in homogenous race paradigms. According to Arcidiaconoa and Nicholson (2005), the recognition of peer influence as a factor in determining student academic outcomes drives medical schools to place students in cohorts or paradigms marked by academic capability. According to Sacerdote (2001) though peer influence evidenced in cohorts or cohabitation 
situations enhanced students' academic performance, it did not determine student college major choices nor influence students' grade point averages.

In a study investigating group effects among cadets in the United States military academy, Lyle (2007) examined random assignment of individuals into groups while using a complex system of synthesis to look out for ,common shocks’ which may affect the level of group effects. He also examined subject pre - existing behavior and how social groups affect an individual's behavior. Lyle (2007) concluded that social groups at West Point influence the major choices of freshman cadets and also influence their decision to commit to the army. It must be added as per Lyle's (2007) analysis that the bulk of freshmen and sophomores tend to go into engineering primarily because West Point is highly regarded as an institution with a reputation for that discipline. Army cadets also have to commit to five year tenure in an officer capacity.

\section{Attendant Effects of Parental Influence during the College Major Selection Process}

Besides the effect of peer influence on college major choices, there is literature that suggests that parental influences also impacts the college choice decisions students make (Bourdieu, 1990). In a study examining the effects of parental occupation and attendant socioeconomic effects on student college major choices, Lepel (2001) reveals that parental occupational backgrounds strongly determine college major choices of students. Thus male students from a family where the father has a high paying job or position tend to aim for high paying majors like business or the hard sciences. Both male and female students were impacted strongly by their fathers occupation while women whose parents were on a high socio economic strata chose majors based on passion as opposed to money since they felt secured financially as a result of their parents. 
The involvement of parents during the college major decision making process is not a sudden occurrence. Parental involvement as per the literature starts rights from the middle school days and still lingers on during college admissions, funding quests, and the college major choice process itself. Among a myriad of factors such as information brochures, student decision making processes, potential college choices, parental encouragement is one of the strong indices in the choice process (Cabrera, La Nasa, 2000). The effect of parental input on student college major choices goes a bit beyond just the socio economic status of students' parents or guardians. The sort of household students come from also determines to a large extent what majors they choose (Corcoran and Courant, 1985). In traditional households where gender roles are drawn, female students will be naturally drawn to female oriented majors while male students will scout out for male oriented majors. Students whose mothers break the mold of traditional households by working outside the home in high paying jobs are more likely to engender their children unconsciously to choose male dominated, high skill set jobs (Douvan, 1976, p. 7).

The literature on college major choice process though scanty, provides an overview of the factors that define student thought processes when making life authoring decisions such as choosing a college major. The literature thus far has been split with regards to narrowing down a core set of factors that propel student choice processes. Mention has been made of student intrinsic interests (Kimweli and Richards, 1999), consideration of financial propensity postgraduation (Thomas and Zhang; 2005)), peer influence and parental influence (Arcidiaconoa and Nicholson, 2005). Mention has also been made of a recursive characteristic of generation Y kids to seek a nod of approval from parents, guardians or any person or group of persons whom they think can help them navigate college major options. The major selection process as per the 
literature is therefore a multifaceted process which involves intrinsic, parental or peer influence as well as the consideration of economic indicators. 


\section{Chapter III - Methodology}

\section{Overview}

The process of college major selection as suggested in the literature is a complicated process transcending apt decision-making skills, economic propensity as well as familial and peer support systems (Malgwi, Howe\& Burnaby, 2005; Kimweli and Richards, 1999; Thomas and Zhang, 2005; Montmarquette, Cannings \& Mahseredjian, 1997\& Bourdieu 1990). Bourdieu (1990) affirms that habitus, the influence derived from one's socio-cultural background has the tendency to define how one negotiates or embraces an opportunity. An absence of cultural capital places the student in a disadvantaged position when it comes to recognizing potential opportunity and utilizing it. The current study adopted a mixed method approach to help in examining the different thought processes, conditions and phenomena that influence students during the college major selection process. An analysis of information regarding research participants, instruments, and research procedures and data analysis patterns are discussed in the ensuing sections.

\section{Research Participants}

Research participants recruited for this study were twofold: freshmen and sophomores for the quantitative component of the study and university recruitment staff for the qualitative components of the study. Details pertaining to the two groups are discussed on the next page.

\section{Freshmen and Sophomore Participants}

A total of 466 freshmen and sophomores advised at the Undergraduate Advising Services Center were recruited for this study. The decision to recruit freshmen and sophomores stemmed from the fact that major selection is done primarily at this stage in students' class rank. 
Students are normally eligible to get into some departments during their sophomore year (29 credits hours). They also officially declare majors when they become rising juniors. Student demographics for the current research were varied though the majority of respondents were primarily Caucasian. Out of the 466 freshmen and sophomores who responded to the surveys, 89.3\% were Caucasian. African American students made up five percent of the survey sample with other races making up $2 \%$.

\section{Figure 1: Respondent Demographic Information}

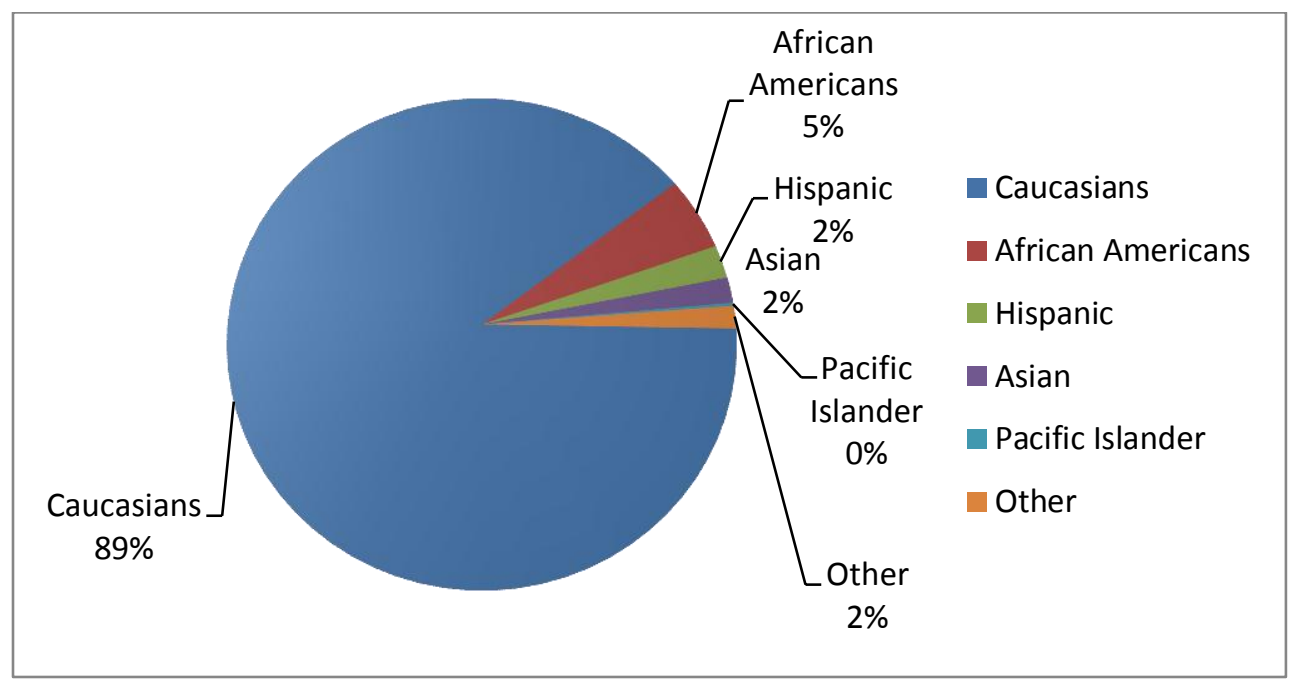

In terms of academic classification, there were 16 first semester freshmen (3.5\%), 293 second semester freshmen (63.0\%), 20 first semester sophomores (4.3\%) and 134 second semester sophomores (28.8\%). Figure 2 on page 31 has a graphical representation of survey respondents' class ranks. Respondent residency backgrounds were split primarily between in state status (45.6\%) and out of state status (52.7\%). International student and non - traditional populations constituted 1.7 percent of the respondent sample. A graphical representation of the respondents' residency status can also be found on page 31 . 
Figure 2: Student Respondents' Class Rank

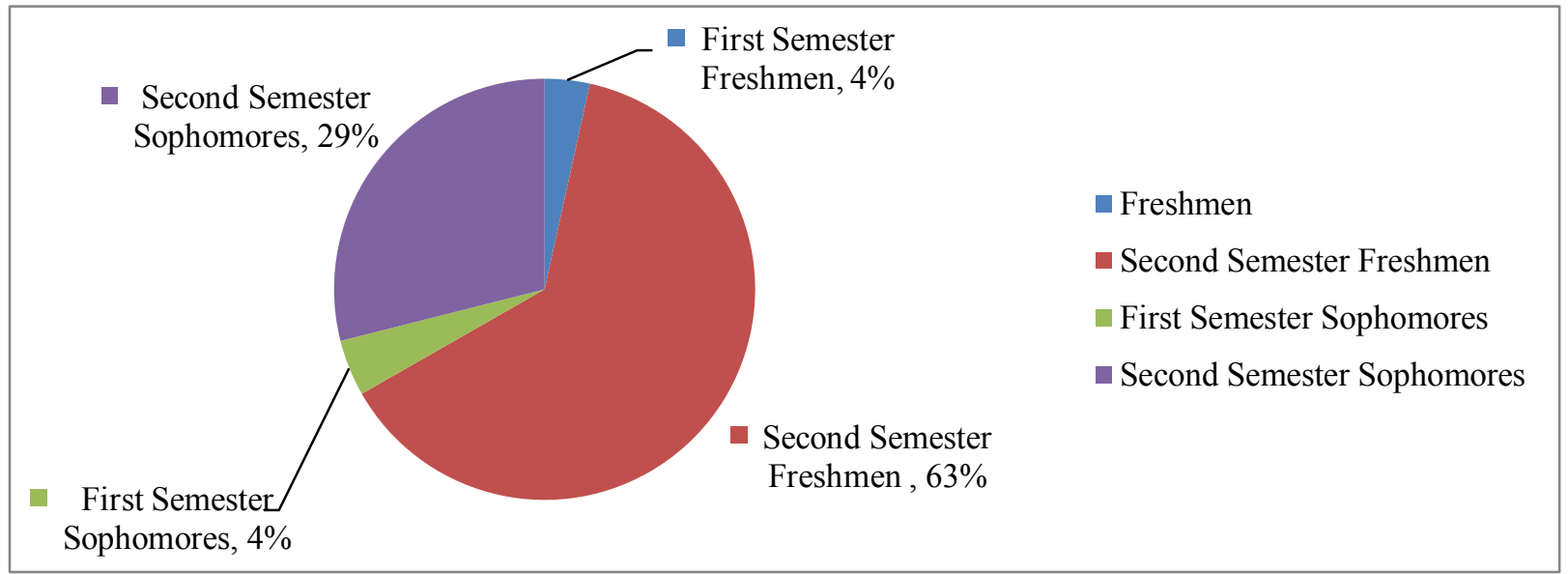

Figure 3: Respondents Residency Status

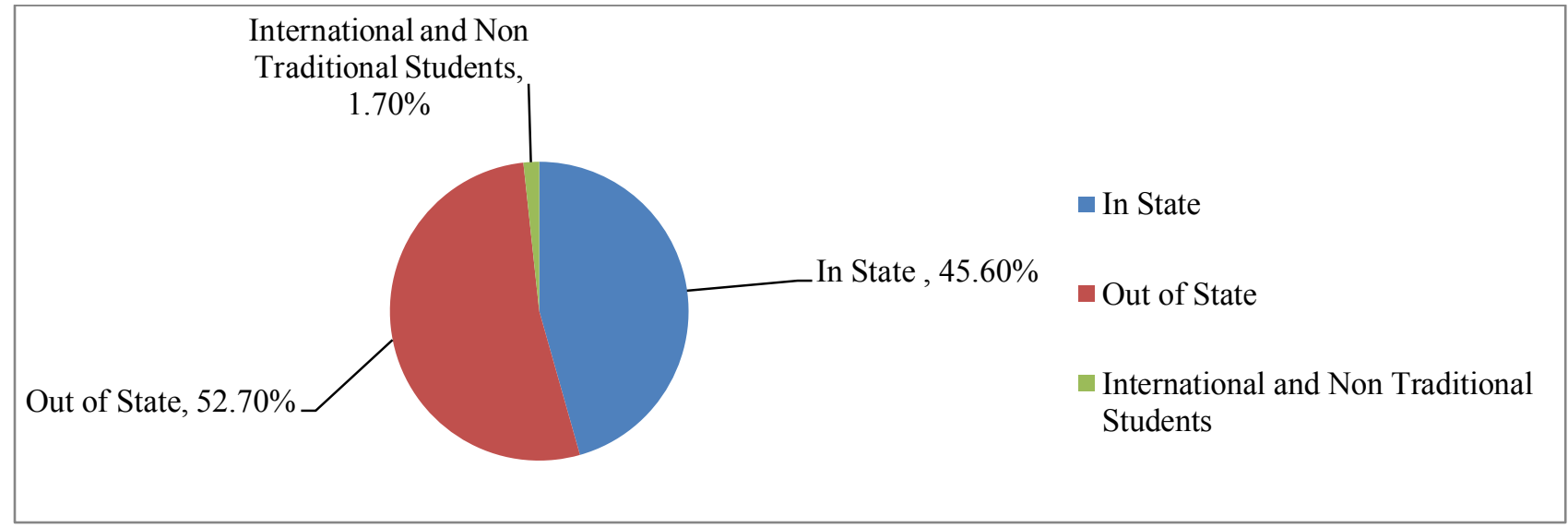

Survey participants were drawn from three sections of a Cultural Anthropology class

(Sociology 105) which happens to be a major entry requirement for students pursuing sociology, criminology, and nursing majors though some students take it as a general elective. Student representation in the three classes was thus very diverse in terms of disciplines, class rank or residency status. To help with distinguishing students' discipline designations, data pertaining to students' major classifications was categorized according to the colleges that offered those majors. 
Students from the College of Arts and Sciences made up the largest pool of respondents $(40.3 \%)$ in the study. Business students constituted $18.3 \%$ of the sample while students from the School of Health Sciences made up about $11.4 \%$. Engineering students made up $6.2 \%$ of the sample while students from the College of Physical Education constitute comprised $2.3 \%$ of the sample. Almost two percent of the survey respondents were from the College of Agricultural Sciences and 5.4\% came from the College of Education. Undecided students in terms of major classification made up $9 \%$ of the sample. Table 1 below provides a tabular representation of student major classifications.

Table 1 : Survey Respondents Major Classification

\begin{tabular}{|l|l|l|}
\hline \multicolumn{1}{|c|}{ College Major } & \multicolumn{1}{|c|}{ Frequency } & \multicolumn{1}{c|}{ Valid Percent } \\
\hline College of Agriculture & 9 & $1.9 \%$ \\
\hline College of Physical Education & 11 & $2.3 \%$ \\
\hline Education & 25 & $5.4 \%$ \\
\hline Engineering & 29 & $6.2 \%$ \\
\hline General Studies & 42 & $9 \%$ \\
\hline Health Sciences & 53 & $11.4 \%$ \\
\hline School of Business & 85 & $18.3 \%$ \\
\hline Arts and Sciences & 186 & $40.3 \%$ \\
\hline
\end{tabular}

\section{Educational Background of Respondents' Parents or Guardians}

To help ascertain the role parents play in the college major choice process, students were asked questions regarding the highest educational level their parents or guardians have attained. This question was embedded in the question pool to examine what level of influence parents might have on students during the college major selection process. 
Fifty - four percent of survey participants had parents who had received a college education. Twenty - five percent of survey respondents noted that their parents were high school graduates while $11.7 \%$ of them mentioned that their parents had professional degrees. There were also respondents whose parents had received a doctoral degree (4.1\%) as well as some with vocational degrees $(2.4 \%)$. A small segment of the participants constituting $2.2 \%$ wrote other when asked of their parents' educational background. Table 2 below illustrates the educational backgrounds of the respondents' parents or guardians.

Table 2 : Parents Educational Background

\begin{tabular}{|l|l|l|}
\hline Educational Background & Frequency & Valid Percent \\
\hline High School & 117 & $25.3 \%$ \\
\hline College & 252 & $54.4 \%$ \\
\hline Vocational & 11 & $2.4 \%$ \\
\hline $\begin{array}{l}\text { Professional Degree } \\
\text { Law,MD,DDS) }\end{array}$ & 54 & $11.7 \%$ \\
\hline $\begin{array}{l}\text { Doctoral Degree } \\
\text { (PhD. EdD) }\end{array}$ & 19 & $4.1 \%$ \\
\hline Other & 10 & $2.2 \%$ \\
\hline
\end{tabular}

\section{University Recruitment Officers}

A total of six recruitment officers were interviewed for the qualitative component of this study. University recruitment staffs are very pertinent to the current research because of the role they play in getting students into the university. This places them at the heart of the college major choice process as they continue to guide prospective students to different departments in the university. To help reach a wide expanse of prospective students, the university's recruitment staff are scattered across different regions spanning West Virginia, Ohio, New Jersey, New York 
just to mention a few. In view of this their responsibilities and their interactions with prospective students vary as per what region they are assigned. Interviews with the recruitment officers revealed that they all have varying academic backgrounds in areas such as creative marketing, public relations, MBA and Hotel Management.

\section{Protection of Human Subjects}

All subjects chosen for the study received a research protocol spelling out the reason for the impending study. They also received an assurance of anonymity and confidentiality regarding any views or personal information required as part of the research. To ensure anonymity no mention implicit or implied was made regarding respondent names or their place of abode. Respondents were also informed of the absence of any codes or identification mechanisms that can potentially lead to a trace of their identity.

\section{Instruments Used in Data Collection}

This current research employed a mixed methods approach towards examining the factors that define students' college major choices. The quantitative component of this study was carried out using a 21 question survey made up of Likert Scale and yes/ no question types (See Appendix D). The qualitative component of the study utilized a 10 question interview prompt for interviewing university recruitment staff (See Appendix E). The third part of the study involved a document analysis of college brochures and view books procured from the university recruitment office. The researcher also used note pads and a voice over internet service called Skype to hold phone interviews for two of the recruitment officers who were out of state at the time of the interview. 


\section{Procedures Used}

As mentioned earlier the current research endeavor sought to examine the college major selection process among freshmen and sophomores advised at the university's undergraduate advising center. The study adopted a mixed method approach involving the use of a 21 question quantitative survey, a qualitative component featuring 10 interview questions for recruitment officers and a document analysis of college brochures and view books. The quest to understand the major selection process was guided by four overarching research questions which are:

R.Q.1) How does the prospect of financially rewarding jobs influence the major selection process by freshmen and sophomores at West Virginia University?

R.Q.2) To what extent does a student's family influence the college major choice process?

R.Q. 3) To what extent does a student's friends or peers influence the college major choice process?

R.Q.4) To what extent does a student's interest in a major affect the college major selection process?

To answer the overarching research questions, the quantitative surveys and qualitative interviews administered to student respondents and university recruitment staff reflected the main research themes. Research question one was answered using survey questions $10^{4}, 11^{5}, 13^{6}$ and $19^{7}$. Research question two was aligned with survey questions $10^{8}$ and $13^{9}$.

\footnotetext{
${ }^{4}$ Likert Scale item three

${ }^{5}$ Likert Scale item three

${ }^{6}$ Likert Scale item 4 and 9

${ }^{7}$ Yes /No Questions

${ }^{8}$ Likert Scale item 5

${ }^{9}$ Likert Scale item 3
} 
Research question 3 was matched with survey question $10^{10}$ while research question 4 was answered using survey questions $10^{11}, 11^{12}, 13^{13}$ and $18^{14}$ on the quantitative survey instrument ${ }^{15}$. Table 3 below shows a matching pattern of research questions and what corresponding sets of quantitative or qualitative instruments helped in answering those questions.

Table 3 : Research Question and Matching Research Instrument Table

\begin{tabular}{|l|l|l|l|}
\hline $\begin{array}{l}\text { Research } \\
\text { Questions }\end{array}$ & $\begin{array}{c}\text { Corresponding } \\
\text { survey questions }\end{array}$ & $\begin{array}{c}\text { Corresponding } \\
\text { Interview Questions }\end{array}$ & $\begin{array}{c}\text { Corresponding } \\
\text { Document Analysis } \\
\text { Themes }\end{array}$ \\
\hline RQ1 & $\mathrm{SQ}^{16} 10,11,13 \& 19$ & $\mathrm{IQ}^{17} 1,2,3,5 \& 8$ & $\mathrm{~T}^{18}$ \\
\hline RQ2 & SQ $10 \& 13$ & IQ 4 & No matching themes \\
\hline RQ3 & SQ 10 & IQ $3 \& 6$ & $\mathrm{~T}^{19}$ \\
\hline RQ4 & SQ $10,11,13 \& 18$ & IQ 4 & $\mathrm{~T}^{19}, \mathrm{~T}^{20} \& \mathrm{~T} 4^{21}$ \\
\hline
\end{tabular}

\section{Research Design}

The study adopted a mixed method approach utilizing both quantitative and qualitative analysis with regards to examining the intricacies that gird the college major selection process. The study, which was in three parts, involved the administration of surveys, interviews and document analysis of college brochures and view books. The decision to use a mixed methods

\footnotetext{
${ }^{10}$ Likert Scale item 2

${ }^{11}$ Likert Scale item 1

${ }^{12}$ Likert Scale item 6

${ }^{13}$ Likert scale items 1, 5and 8

${ }^{14} \mathrm{Yes} /$ no question

${ }^{15}$ Please refer to Appendix D for a copy of the survey questions.

${ }^{16}$ Abbreviation for survey question

${ }^{17}$ Abbreviation for interview question

${ }^{18}$ Theme 6: Employment Possibilities

${ }^{19}$ Theme 2: Community Service Outreach

${ }^{20}$ Theme 3: Emotive Appeal

${ }^{21}$ Theme 4: Technological Innovation
} 
approach for the current study was to effectively determine which factors or combination of factors influence freshmen and sophomores during the college major selection process.

Quantitative analyses are good for arriving at "generalizable" results; however they fail to thoroughly identify the intricacies embedded in participant responses. The use of qualitative methodologies on the other hand allows for the use of a gestalt approach which helps the researcher piece together the hidden dimensions of the college major selection process through a process of deconstruction and reconstruction. Such a process according to Patton (2002) yields a rich and deep tapestry of research respondents' perceptions. This quality is most often lost when data from surveys are only represented in percentages and numerical indices. Another advantage of the qualitative method is the opportunity it affords the researcher to delve into the respondents experience and the researchers' own experience within the respondents' experience.

Since the study adopted a three-step approach towards identifying student major selection patterns, data collected from the quantitative survey, qualitative interviews and document analysis of college brochures and view books were synthesized. The researcher administered the quantitative surveys in three Cultural Anthropology classes. Prior to answering the surveys, the respondents were handed consent forms from the institutional review board detailing the purpose, scope and duration of this survey. All respondents were given assurances of anonymity and told that they had the right to refuse an answer to any question/ questions they felt uncomfortable responding to (See Appendix C). There were 21 questions made up of Likert scale, as well as, yes/ no question types. Questions elicited information such as respondent ethnicity, academic status; major, parental educational background as well as Likert scale items aimed at deciphering what factors guided the students' college major choices. Some of the questions were repetitive and this was done purposely to test student responses to how certain 
factors such as economic propensity as well as peer and family influence impacted students' major choices.

Responses from the surveys were manually inputted into an excel file and tagged with unique numerical codes. Each item on the 21 question survey was tagged with a unique number such as "1" for males and "2" for females to facilitate easy statistical analyses in PASW 18.

While conducting the qualitative interview component of the study, the researcher took detailed notes of the respondents' viewpoints recording every detail as was articulated from the respondent. This meant that even unconventional language use and colloquialisms were noted accordingly. To ensure respondent privacy, pseudonyms were used in place of real names. Interview transcripts were read repeatedly during the coding process and themes which richly portrayed the viewpoints of the recruitment staff were crafted. The emergent patterns were scattered across the following themes: The Mission and Character of a Successful Recruiter, Publicizing WVU, Challenges of the Recruitment effort and last but not the least, Reminiscences about the College Major Selection Process, the Recruiter's Perspective. The above themes served as coding parameters for analyzing interview transcripts and these were then aligned with the relevant research questions they addressed (See Page 36 for matching table).

The document analysis portion of the study also involved repeated reading of college brochures and view books to find out if there was any reinforcement of overarching themes such as economic propensity, peer input, and parental investment in the collegiate experience or even any mention of an avenue to promote or encourage student interest.

The involvement of recruitment officers from West Virginia University's recruitment office was meant to buttress student perceptions of what factors influenced the college major selection process. The use of direct quotations from recruitment officers while rendering their perceptions 
about college recruitment and major selection unveiled a rich depth of data with regards to how college recruitment affects students' college major choices.

The ability to interpret numerical indices of students' perception regarding their thought processes during major selection while reading into the perceptions of recruitment officer staff was very telling. According to Patton (2002), the theory of Verstenhern entreats the researcher to go beyond numerical indices by deciphering human actions and consciousness. In other words there is a need to embed human perceptions beyond the need to generalize collective views.

The advantage of using a mixed method approach lay in my ability to delve simultaneously into a quantitative and qualitative data pool as I tried to understand the different facets of the college major selection process. The three sets of data pools allowed for an effective synthesis of student, recruiting officers and documents analysis strands in a bid to discover answers to the four overarching research questions. Each research question as shown in Table 3 on page 36 was tied to data sets from both the quantitative and qualitative components of the study. The quest to understand the college major selection process was thus multi-faceted by virtue of the fluid nature of data synthesis involving student survey inputs, college recruiting officers' viewpoints as well as implied assumptions drawn from the literature on college brochures which informed the analysis of the artifacts ( Krippendorf's, 2004; Labaree, 1997). The strength of conducting a mix method study such as this lies in the ability to have a multi - dimensional interpretation of results in relation to the overarching questions that guide the study. This phenomenological approach allows for an effective comparison of student views with recruitment officer perceptions while foregrounding the philosophical underpinnings of the university's colleges via the analysis of college brochures and view books with the view to finding out how the data resonates with student perceptions about the college major selection process. 


\section{Data Analysis}

The analysis of data was done in three stages. The first involved the analysis of data from the 21 question survey handed out to students in the three Cultural Anthropology classes. After coding via excel and running the raw data in PASW 18, the researcher run frequencies and percentages via the statistical software to determine the degree of influence that financial job prospects (RQ1), family influence (RQ2), Peer Influence (RQ3), and student intrinsic interest (RQ4) have on student major choices. The frequencies and percentages computed from the quantitative survey raw data were selectively analyzed in line with the respective research questions they pertain to help highlight students' perceptions about what combinations of factors in the research questions guided their college major choices. The synthesized data from the quantitative study was then infused with relevant portions of interview transcripts, which answered the overarching questions posed in this research. For instance, three of the six themes in the document analysis component of the research were matched up with research questions 1 , 3 and 4 (See Table 3 on page 36).

Content analysis was done on brochures from ten colleges namely: 1)Human Resources and Education, 2)Davis College of Agriculture, 3)School of Dentistry, 4)College of Law, 5)College of Creative Arts, 6)College of Business and Economics, 7)School of Medicine, 8)Perley Isaac Reed School of Journalism, 9)Eberly College of Arts and Sciences, and 10)School of Pharmacy. Content analysis involves a process of pattern recognition that involves a search of recurring words or themes (Patton, 2002). The main aim of this process is to make sense of data with the view to "identify core consistencies and meanings" (Patton, 2002, p.453). Qualitative research is mistakenly judged as falling short of the rigors of scientific research even though it adopts empirical methods in analyzing visual, textual or oral data (Krippendorf, 2004). 
The process of content analysis also goes beyond description of data; it also involves analyzing the data and drawing inferences (Holsti, 1969).

Emergent patterns were deciphered through the development of themes using Labaree's (1997) conceptual notions of American educational philosophy. According to Labaree (1997) schools embrace qualities of democratic equality, social efficiency and social mobility. Democratic equality according to Labaree (1997) resonates with the idea of seeing education as a "public good" aimed at preparing the youth to actively and competently engage in "political roles" in their communities (p.42). Social efficiency still advances the notion of a public good or participatory democracy of a sort but focuses more on economic competence, preparing the youth to contribute economically to the community by equipping them with the wherewithal to succeed. Social mobility epitomizes the very essence of a capitalist mindset where the school is a hotbed for the production of labor. Education is portrayed as a "commodity" aimed at students with a "competitive advantage" on the turf social advancement. Thus the first two ideals profess a public good whereas the last ideal is a "private good" for the betterment of the individual.

The document analysis process was done using Krippendorf's (2004) four stages of content document analysis involving: sampling, Unitizing, Reduction and Inference making as a guide. College brochures were acquired via a convenient sample. After interviewing the recruitment staff, one of the respondents upon my request, took me down to the recruitment material depot and handed me copies of the brochures they use during recruitment campaigns.

The process of unitizing involved the development of themes using Labaree's (1997) conceptual analysis of the underlining philosophies of American education. The diagram on page 42 is a visual rendition of the pattern of content analysis used. 


\section{Figure 4: Pattern of Content Analysis}

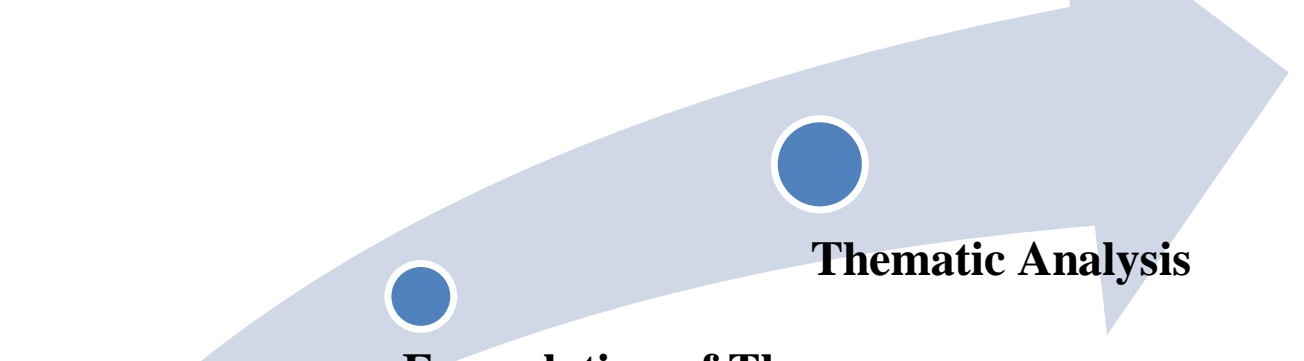

Formulation of Themes

Labaree (1997)

\section{Content Analysis}

Krippendorf (2004)

Based on Labaree's (1997) conceptual analysis of institutional educational philosophies (sampling, Unitizing, Reduction and Inference making), I generated six themes to help me carry out a visual and textual analysis on seven college brochures from the Colleges of Education, Journalism, Business and Economics, School of Pharmacy, Dentistry, Arts and Sciences, Law and medicine. I also reviewed three view books, two from the colleges of Engineering and Creative Arts respectively. The third view book was a university wide effort and I thought of adding that to sum up the philosophies and missions that define the university's character and image to prospective students. Content analysis of these college brochures and year books were done using six main themes namely: Establishing credibility, Community Service Outreach, Emotive Appeal, Technological Innovation, Aesthetic Presence and last but not the least, Employment Possibilities. The analyses were done using the themes listed above. The three college view books were however analyzed differently as they also included visual images. 
Analyses of the college brochures and view books involved textual analyses during the coding process. Words like "jobs", “employment" "renovated”, "new”, "awards”, or any words that alluded to a college's structural edifices, reputation of faculty, perceptions of students and economic propensity were examined along the lines of the six themes enumerated above. The aim was to look out for through for any messages that possibly could influence the choices of students who read these brochures. The filtering of words that connote economic promise, structural or technological innovations, faculty prowess or an enabling environment accepting of student advancement formed the pivot on which analyses revolved.

\section{Summary of Methodology}

A mixed method approach was used in determining what factors guide students during the major selection process. Quantitative surveys, qualitative interviews and document analysis were employed to help in the triangulation of research results. Relevant portions of data collected from the three strands of the study were synthesized and matched with the overarching research questions to help tease out emerging patterns related to factors that impact students' eventual major choices. 


\section{Chapter IV: Results}

This chapter reports the results gathered from this mixed methods study. The reportage has been done in the order of the overarching research questions that guide this study. A synthesis of relevant results from the three strands of the study namely: quantitative surveys, interviews and document analysis were aligned with the respective research questions they addressed. The last half of chapter four is a detailed analysis of recruitment officers' interviews and college brochures and view books. These accounts are holistic renditions of all the analyses as the results reporting excluded certain rich details that were not directly pertinent to the study.

The aim of this research was to examine what factors influence major selection processes among freshmen and sophomores advised at West Virginia University's Undergraduate Advising Services Center. This research endeavor as mentioned in previous chapters was guided by the following research questions:

\section{Research Questions}

R.Q.1) How does the prospect of financially rewarding jobs influence the major selection process by freshmen and sophomores at West Virginia University?

R.Q.2) To what extent does a student's family influence the college major choice process?

R.Q. 3) To what extent does a student's friends or peers influence the college major choice process?

R.Q.4) To what extent does a student's interest in a major affect the college major selection process? 
The questions listed above informed the direction and analyses carried out in this mixed method study. Besides the qualitative component of this study which involved interviews with recruitment officers as well as document analysis of college brochures, surveys were distributed to four hundred and sixty-six students $(\mathrm{N}=466)$ drawn from three Cultural Anthropology classes (Sociology 105). The survey consisted of twenty- one questions aimed at deciphering student perceptions about the college major selection process. The complex nature of the college major choice process as per the literature on college choice informed my decision to include college recruiters and also conduct a document analysis on college brochures to help in the triangulation of the results. As Bourdieu (1990) posits the individual is heavily influenced by habitus (social and cultural backgrounds). Since students grow up among family and friends and also patronize college recruitment services, it is safe to assume that their perception of the college major choice process is multifaceted. Reportage of research results from all three components of the current study will be done in the order the main research questions are listed.

\section{Results for Research Question One}

The prospect of financially rewarding jobs as it relates to students' propensity to select a particular major over another was the focus of research question one. Segments of the study relevant to responding to this discourse were extracted from quantitative survey questions $10^{22}$, $11^{23}, 13^{24}$ and $19^{25}$. Interview questions $1,2,3,5 \& 8$ (Please refer to Appendix E). It was also prudent to add sections of the document analysis of college brochures which addressed the theme of financial reward.

\footnotetext{
${ }^{22}$ Likert Scale item 3

${ }^{23}$ Likert Scale item $3 \& 5$

${ }^{24}$ Likert Scale item 4

${ }^{25}$ Yes/no question
} 
The theme of "Employment Possibilities" the sixth theme in the brochure analysis section was also synthesized in the reportage of results for research question one. The results will be stated in the order listed above in the consequent paragraphs.

When students were asked how the prospect of financial rewards influenced their choice of a major, $21.5 \%$ of them said that they were greatly influenced by that prospect. About $29.6 \%$ said that they were influenced quite a bit while $21.7 \%$ said they were somewhat influenced by the thought. $13.8 \%$ of students who took the survey said considerations about financial rewards post-graduation were miniscule in the decision making process for a major. For $13.4 \%$ of survey respondents, the issue of financial rewards in the future was not factored in the major selection process at all. Table 4 is a representation of the respondents' perceptions about the role financial reward plays during the major selection process.

Table 4 : Financial Reward In the future

\begin{tabular}{|l|l|l|}
\hline Likert Scale Values & Frequency & Valid Percent \\
\hline A great extent & 98 & $21.5 \%$ \\
\hline Quite a bit & 135 & $29.9 \%$ \\
\hline Somewhat & 99 & $21.7 \%$ \\
\hline Little & 63 & $13.8 \%$ \\
\hline Not at all & 61 & $13.4 \%$ \\
\hline
\end{tabular}

When asked about how the prospect of job advancement in the future influenced the eventual choice of their college majors, $21.6 \%$ of survey respondents said they were influenced greatly whereas $35.3 \%$ of the respondents said they were influenced quite a bit. For $23.4 \%$ of the students, prospects of job advancement somewhat played a role in their choice of a college major. The propensity to advance in the job market however played a "little" role in the choice of 
$8.4 \%$ of the students who took the survey. About $11.2 \%$ of students who took the survey did not even consider job advancement prospects in their major choice. Table 5 outlines in tabular format, the perceptions of survey respondents with regards to the consideration of job advancement potential of any major post-graduation during the major selection process.

Table 5 : Prospects of Advancement in the Job Market

\begin{tabular}{|l|l|l|}
\hline \multicolumn{1}{|c|}{ Likert Scale Values } & \multicolumn{1}{|c|}{ Frequency } & \multicolumn{1}{c|}{ Valid Percent } \\
\hline A great extent & 100 & $21.6 \%$ \\
\hline Quite a bit & 163 & $35.3 \%$ \\
\hline Somewhat & 108 & $23.4 \%$ \\
\hline Little & 39 & $8.4 \%$ \\
\hline Not at all & & $11.3 \%$ \\
\hline
\end{tabular}

Survey participants were also asked hypothetically if they will select a particular college major based on attestations of job advancement prospects from someone working in a similar field. $21.6 \%$ of students said they would patronize the idea readily while $30 \%$ of students said they would give the idea much consideration. $22.7 \%$ of respondents said they will somewhat give thought to the information while $13.4 \%$ of survey respondents said they will not take a keen interest in the evidence. For $12 \%$ of the respondents however, prospects of job advancement will not come up at all during major selection. Table 6 on page 49 is a representation of frequencies and percentages about survey respondents' perceptions concerning job advancement prospects and how that affects their final college major choices. 
Table 6 : Living Testimony of Job Prospects from Someone you know

\begin{tabular}{|l|l|l|}
\hline Likert Scale Values & Frequencies & Valid Percent \\
\hline A great extent & 98 & $21.6 \%$ \\
\hline Much & 136 & $30 \%$ \\
\hline Somewhat & 103 & $22.7 \%$ \\
\hline Little & 61 & $13.4 \%$ \\
\hline Never & 56 & $12.3 \%$ \\
\hline
\end{tabular}

Job security was instrumental in the college major selection for $23.5 \%$ of students who participated in the survey. A little over $29 \%$ of students who took the survey said they were influenced quite a bit by the thought of job security. For $20.6 \%$ of student respondents, job security was somewhat a concern during their selection of a college major whereas $13.8 \%$ of students said they gave no thought to that prospect. When survey participants were asked if they would stay in the same major if all financial rewards associated with all majors were the same ${ }^{26}$, $80.6 \%$ of students answered yes while $17.8 \%$ said no. Table 7 on page 50 is a representation of frequencies and percentages depicting survey participants' views about job security and how that impacted their eventual college major choice.

\footnotetext{
${ }^{26}$ Question 16 - yes/no question
} 
Table 7 : Job Security

\begin{tabular}{|l|l|l|}
\hline Likert Scale Values & Frequency & Valid Percent \\
\hline A great extent & 108 & $23.5 \%$ \\
\hline Quite a bit & 138 & $30 \%$ \\
\hline Somewhat & 96 & $20.6 \%$ \\
\hline Little & 64 & $13.9 \%$ \\
\hline Not at all & 54 & $11.7 \%$ \\
\hline
\end{tabular}

The next couple of paragraphs will examine recruitment officer perspectives with regards to the issue of financial rewards in relation to students' major choice. Though the questions listed do not have any bearing directly to financial rewards, the researcher asked those to elicit respondent perceptions on what drives the recruitment process. An attempt was made not to lead recruitment officers to any answer purporting to the promotion of the university via a message of economic promise.

When asked what the underlining mission of the recruitment center was, the recruitment officers all mentioned the idea of content mastery of the university's course offerings. They stressed this quality because they believed that was their spring board to measuring success. They talked about painting the big picture to students, giving them details through active advertising about the ins and outs of the school so students can decide for themselves. They however made no mention of promoting majors by way of economic possibilities or opportunities; the choice was left to the student to make.

Having discussed the desired qualities of a recruitment officer, I went on to inquire what the main selling points were during the recruitment process. Once again no mention was made 
with regards to financial promise. The recurring theme centered on tuition costs and how that made a difference for out of state students compared to tuition rates in their home states. It seemed apparent that the recruitment officers' work was cut out for them as the competing universities and colleges in the recruitment regions fell short of attracting students because of high attendance costs. There were students who also came to WVU because they were on a reciprocity agreement which is a pact between neighboring states to allow students from other states to attend college at in state tuition rates if the major they were pursuing was not offered in their home states.

Drawing the point closer to home, I asked the recruitment officers what majors drew the most students to WVU. They stressed a high patronage of STEM programs (science, technology, engineering and math). They were also all unanimous in repeatedly mentioning the following majors as their key selling points: Forensics, Engineering, Nursing, Pharmacy, Physical Therapy $^{27}$, and Business. Majors in the arts were seldom referred to and when they did reference majors in the arts, they mentioned political science and music.

To find out whether prospective clientele showed any interest in receiving any information about the recruitment process, I asked the recruitment staff about some of the concerns their clients have expressed in the past concerning the pursuance of a prospective college degree. The issue of cost kept coming up again but one recruitment officer said her clients go beyond the issue of cost and inquire about internships, academic advising and job opportunities post-graduation.

\footnotetext{
${ }^{27}$ WVU no longer offers the Physical Therapy major at the undergraduate level.
} 
The theme of Employment Possibilities from the document analysis section was also examined in relation to research question one. After reviewing all college brochures and view books, I examined any phrases that suggested economic promise or the touting of job prospects post-graduation. Most of the colleges did not readily front economic prospects of their majors though it was done implicitly. The Journalism school mentioned efforts to help students secure jobs in passing. They however stressed that a hands on educational experiences with a heavy emphasis on internships. Their graduates as per their brochures work in "top news organizations and communication agencies around the world." Thus students who go to the journalism school supposedly stand a high chance of landing jobs in prestigious settings which may reward them appreciably. Other colleges like the education department just mentioned the provision of job search services and interview prepping.

The Law School however stated implicitly in numerical terms that they have a 95.2 percent job placement record which normally happens barely nine months after graduation. They went on to say that graduates from the college "earn top salaries" at law firms throughout the United States and worldwide.

The School of Business acknowledges that the job hunt process is "important" to students and parents so they do well to facilitate student employment post-graduation. This is done by bringing recruiters to the door step of the college to make the job search process easier. The center also houses a Center for Career Development "which offers professional development courses" which help students develop interviewing, business etiquette and résumé writing skills.

The report of data relevant to research question one seems to suggest that the propensity for financial reward which translates into jobs has a hold during student decision making. In recruitment circles advertising of college majors in the STEM fields (science, technology, 
engineering and math), business, forensics, nursing and pharmacy speaks volumes to students' consciousness about the financial rewards post-graduation. The unpopularity of majors in the arts speaks volumes as well about the major selection process.

The fronting of job placement opportunities by the Business and Law schools also ties in strongly with the presupposition that college major choice processes are not devoid of the consideration of economic indicators post-graduation.

\section{Results for Research Question Two}

Research question two examined the extent to which a student's family influences the college major selection process. Survey questions 10,28, 13, and 29 had relevant themes pertaining to this question. Interview question 4 (Please see Appendix E) also had some relevance to the discussion on familial influence. No corresponding themes were found in the document analysis data which addressed the issue of familial influences directly.

The role of family members in the pursuit of a college experience is inalienable however, the level of influence as per the data on family obligations may differ. A small percentage of students (3.9\%) felt obliged to meet family obligations when selecting a major. A little fewer than ten percent of survey respondents felt that allegiance to family demands played quite a bit of a role in their eventual major choice. Approximately $17 \%$ of survey respondents said that they were somewhat influenced by the thought of meeting family obligations when they chose their major. $22.4 \%$ of respondents said the influence was insignificant while a majority of students (47.4\%) did not feel pressured at all. Please refer to Table 8 on page 54 for a tabular

\footnotetext{
${ }^{28}$ Likert Scale item 5

${ }^{29}$ Likert Scale item 3
} 
representation of student perceptions regarding how the urge to meet family obligations affected their college major process.

Table 8 : Meeting Family Obligations

\begin{tabular}{|l|l|l|}
\hline \multicolumn{1}{|c|}{ Likert Scale Values } & \multicolumn{1}{|c|}{ Frequencies } & Valid Percent \\
\hline A great extent & 18 & $3.9 \%$ \\
\hline Quite a bit & 43 & $9.4 \%$ \\
\hline Somewhat & & $16.6 \%$ \\
\hline Little & 76 & \\
\hline Not at all & 104 & $22.7 \%$ \\
& & $47.4 \%$ \\
\hline
\end{tabular}

When asked how suggestions from parents and siblings affected their college major choices, only $6.4 \%$ of respondents mentioned that parental or sibling input play an immense role in their eventual choice. Twenty three percent of students said they were influenced "much" by the input from their parents and siblings while $31.6 \%$ of respondents said they had somewhat of an influence. The effect of parental or sibling input regarding student major choice was deemed miniscule by $21.6 \%$ of students and $16.8 \%$ of them said that parental or sibling suggestions had nothing to do with their eventual choice of a major. Table 9 on page 55 is a tabular representation of participants' views on parental and sibling suggestions as it relates to their eventual major choices. 
Table 9 : Suggestions from Parents and Siblings

\begin{tabular}{|l|l|l|}
\hline \multicolumn{1}{|c|}{ Likert Scale Values } & \multicolumn{1}{|c|}{ Frequencies } & \multicolumn{1}{c|}{ Valid Percent } \\
\hline A great extent & 29 & $6.4 \%$ \\
\hline Much & 107 & $23.6 \%$ \\
\hline Somewhat & 143 & $31.6 \%$ \\
\hline Little & 98 & $21.6 \%$ \\
\hline Never & 76 & $16.8 \%$ \\
\hline
\end{tabular}

To find out the extent to which parents are involved in the college major decision making process, I asked recruitment officers about who they normally meet with during recruitment drives. A majority of them told me that they interacted primarily with students but also dealt with parents, high school counselors etc. One recruitment staff said she emailed parents to keep them informed of progress on applications or to give feedback on the application process.

\section{Results for Research Question Three}

Research question three examined the role that peers or friends play in the major selection decision process. Relevant portions of survey question 10 were included in the discussions on peer or friend influence. Peer influence as per the quantitative survey played an immense role in the college choice of $2.6 \%$ of the respondents. About $8 \%$ of students felt quite a bit of an influence from their peers when they chose their major. $21.3 \%$ of respondents said that peer influence played somewhat of a role in the determination of their college major choices. Peer influence was not a factor for $29.1 \%$ who deemed the effect of associating with peers to be insignificant in the major selection process. A majority of survey participants $(38.9 \%)$ said that there was no influence whatsoever from peers when they selected their college majors. 
Please see Table 10 below for a representation of frequencies and percentages regarding how peer influence affects students' college major choices.

Table 10 : Effect of Peer Influence on Respondents major choice

\begin{tabular}{|l|l|l|}
\hline \multicolumn{1}{|c|}{ Likert Scale Values } & \multicolumn{1}{|c|}{ Frequencies } & \multicolumn{1}{|c|}{ Valid Percent } \\
\hline A great extent & 12 & $2.6 \%$ \\
\hline Quite a bit & 37 & $8.0 \%$ \\
\hline Somewhat & 98 & $21.3 \%$ \\
\hline Little & 134 & $29.1 \%$ \\
\hline Not at all & 179 & $38.9 \%$ \\
\hline
\end{tabular}

There were no data patterns relevant to research question three from the recruitment officer transcripts. The second theme (Community Service Outreach) in the document analysis segment from the third strand of this research, was however helpful. All the college brochures made mention of the existence of peer networks and how that enhanced the learning cultures and atmospheres in their departments. Students in the school of journalism for instance were said to be involved in group work and community service and their group efforts pay off by way of awards from notable organizations by virtue of their hard work.

Pictures of students on the College of Engineering view book showed students with broad smiles deciphering the complexities of a motorized robot in the glow of summer. Lab settings also featured a hale and hearty environment where peers worked collaboratively on projects. The college view books also showcased students from different disciplines who had 
won prestigious awards and scholarship opportunities some of which earned them visits to distant lands or prestigious places like the Kennedy Space Center. Though the document analysis component discussed may have no direct bearing with student decision making processes, there is the potential overtime for students to buy into the cultures portrayed in college brochures and view books and desire to live out those experiences as well. As the literature on college brochures also mentions, prospective students place a premium on brochures during the college admission process (Hossler, Schmit, \& Vesper, 1999).

\section{Results for Research Question Four}

Student intrinsic interest was the last overarching research question that guided the current study. Besides examining the effect that final reward, familial influence and peer influence had on the college major process, the study also examined how a student's own assertiveness affected his or her choice of a major. Research question 4 was answered using survey questions $10^{30}, 11^{31}, 13^{32} \& 18^{33}$. Interview question four from recruitment officer transcripts was also synthesized with quantitative survey results because it directly addressed the issue of student interest in the major selection process. Relevant themes from the document analysis of college brochures such as "community service outreach", "emotive appeal", and "technological innovation" were also added in the synthesis of data on students' intrinsic interest.

When students were asked the extent to which their passion for their major affected their college major choices, $32.8 \%$ said that they were influenced to a great extent while $29.3 \%$ said that there were influenced quite a bit. For $20.6 \%$ of the study participants their passion played somewhat of a role in their eventual major choice. $7.1 \%$ of survey respondents mentioned that

\footnotetext{
${ }^{30}$ Likert scale item 1

${ }^{31}$ Likert scale item 6

${ }^{32}$ Likert scale item $1,5 \& 8$

${ }^{33}$ Yes/no question.
} 
passion had little to do with their choice while $9.9 \%$ of students didn't even think about passion for the intended major when they made their choice.

The Likert item captioned "students' passion for the major" was reiterated in question 11 of the quantitative survey. Student responses did not change much compared to students' responses to the same item in question ten. $33.3 \%$ of students said that they were greatly influenced by their major as opposed to $32.8 \%$ who said so in question 10 . About $28.3 \%$ of students said they were influenced quite a bit, this percentage was a little lower than the percentage in question ten $(29.3 \%)$. A cross section of students $(18.5 \%)$ said they somewhat considered passion for the discipline when they chose their majors. The number of respondents who chose the "somewhat" option in question ten was higher $(20.8 \%)$. For $11.1 \%$ of survey respondents', passion for the major was an insignificant factor in their choice, this was an increase compared to $7.2 \%$ of respondents who said that in survey question ten. About $8.7 \%$ of respondents said that they did not factor in passion when they settle for a major choice. This number was lower compared to $10 \%$ in survey question ten. Table 11 on page 59 is a rendition in frequencies and percentages of how students' passion for their majors affected their eventual major choices. 
Table 11 : Student passion for the Intended Major

\begin{tabular}{|l|l|l|}
\hline Likert Scale Values & Frequencies & Valid Percent \\
\hline A great extent & 151 & $32.8 \%$ \\
\hline Quite a bit & 135 & $29.3 \%$ \\
\hline Somewhat & 96 & $20.8 \%$ \\
\hline Little & 33 & $7.2 \%$ \\
\hline Not at all & & $10.0 \%$ \\
\hline
\end{tabular}

Survey question 13 asked students the extent to which their own personal research influenced their eventual choice of a major. $27.6 \%$ of them said that their search benefitted them greatly while $35.7 \%$ of students described the influence as "much." $24.1 \%$ of survey respondents said personal research played a role somewhat in their eventual major choice and $9 \%$ of them said their research was insignificant to their eventual choice. For $3.5 \%$ of the respondents, personal research had nothing to do with their eventual major choice. Table 12 on page 60 is a tabular representation of respondent views about how intrinsic interest affects their major choices. 
Table 12 : Arriving at Major Choice through Personal Research

\begin{tabular}{|l|l|l|}
\hline \multicolumn{1}{|c|}{ Likert Scale Values } & \multicolumn{1}{|c|}{ Frequencies } & \multicolumn{1}{c|}{ Valid Percent } \\
\hline A great extent & 126 & $27.6 \%$ \\
\hline Much & 163 & $35.7 \%$ \\
\hline Somewhat & 110 & $24.1 \%$ \\
\hline Little & & \\
\hline Never & 41 & $9.0 \%$ \\
\hline
\end{tabular}

Survey question 13 also asked students how personal research into the short term and long term benefits of chosen major affected their eventual choice. $21.1 \%$ of respondents said that the personal effort paid off greatly while $32.7 \%$ of students said they experienced "much "of an influence through researching. For $26.3 \%$ of the respondents personal research played somewhat of a role while $13.4 \%$ of students felt that personal research was insignificant with regards to their major choices. $6.6 \%$ of respondents said their eventual major choices had nothing to do with personal research. Please refer to Table 13 on page 61. 
Table 13 : Research into the Long and Short term Benefits of Major

\begin{tabular}{|l|l|l|}
\hline \multicolumn{1}{|c|}{ Likert Scale Values } & \multicolumn{1}{|c|}{ Frequencies } & \multicolumn{1}{c|}{ Valid Percent } \\
\hline A Great Extent & 96 & $21.1 \%$ \\
\hline Much & 149 & $32.7 \%$ \\
\hline Some what & & $26.3 \%$ \\
\hline Little & 120 & $13.4 \%$ \\
\hline Never & 61 & $6.6 \%$ \\
\hline
\end{tabular}

Interview transcripts from recruitment officers were also examined to find out the role students play in the major selection process. When recruitment were asked about whom they interacted with mostly during recruitment drives, all but one unanimously mentioned students as the primary contact, followed by parents, high school counselors, fair organizers and alumni. Students as per recruitment officers are thus at the fore front of the college selection process. Research on college brochures indicated that students place very high premium on college brochures as they play an instrumental role in guiding students towards a major choice (Hossler, Schmit, \& Vesper; 1999). It is therefore not surprising that colleges and universities spend large amounts of money in creating catchy brochures which embody their philosophical dispositions. A review of document analysis themes used during the review of college brochures and view books such as: "Emotive Appeal" and "Community Outreach" show the commitment of colleges to emphasize a self-driven ethic when portraying collegiate life in the academy. 
The School of Journalism's emotive appeal is couched in the spirit of a "can do" attitude by its students. They are self-driven and they have ownership of their learning experiences. They independently produce "real work-news stories, broadcasts, campaigns and projects." Students also "work side - by - side with award winning faculty" alluding to the notion of a personalized and supportive learning experience. Thus a supportive but structured environment is in place to enhance and nurture student interest. The college view books also carried a sense that the collegiate experience is enlightening and has the potential to open up vistas of opportunities for graduates. A quote on the university view book says it all: "It was here where my eyes were truly opened to the world... these are experiences I couldn't have gotten anywhere else." The university thus rewards students' efforts and that virtue is imbibed in students when they set foot in the corridors of the academy. There is thus the potential to not only harness student potential but also unconsciously psych them to take pride in edifying themselves so they can be like famous alumni who adorn the pages of the college view books.

The above reportage has looked at how the three strands of this research namely; the quantitative surveys, recruitment officer interviews and document analysis have attempted to answer the four overarching questions which underlie this research. A rendition of recruitment officer transcripts and document analysis is discussed in the following paragraphs. Some of the themes may be repetitive as salient portions relevant to the overarching research questions have been discussed beforehand.

\section{A Detailed Account of Recruitment Officer Interviews}

Admission counselors in West Virginia University play the role of academic ambassadors whose main goal is to advertise the academic offerings of the university to prospective students throughout the country. Although they have resident stations on campus, they are mostly 
stationed in different recruitment zones. Their areas of jurisdiction go beyond the state of West Virginia to include satellite centers in Maryland, Ohio, Central and Western Pennsylvania, Virginia, Washington D.C. as well as surrounding states in the sub region. Besides recruiting mainstream high school graduates for college, West Virginia University's admission counselors also recruit veterans, transfer students and non - traditional students as well.

The decision to include admission counselors in this research endeavor is as a result of their involvement in the recruitment of prospective freshmen to different departments and colleges at WVU. They work hand in hand with school counselors and parents in an effort to match prospective college students with college majors which reflect their academic ambitions. While performing their recruitment duties, staff of the recruitment office may inadvertently influence the academic choices of prospective students.

This informs their inclusion in the current research to ascertain whether they make any impact on freshmen and sophomores during the major selection process. The analysis that follows this introduction is a synthesis of a series of interviews held with recruitment staff in their offices. Interview invitations were extended repeatedly to a total of 14 recruitment officers but only six of them agreed to be interviewed. The other counselors were either out of the office on recruitment assignments (as per automated email alerts) or simply non- responsive to emails.

There were 10 interview questions covering topics such as the mission and mark of a successful recruiter, publicizing WVU, challenges of the recruitment effort and last but not the least, reminiscences about college major choices; the Recruiter Perspective. A synthesis of respondent perspectives regarding the topics enumerated above will follow this introduction. The names listed in the interview transcript rendition are all pseudonyms and are in no way traceable to the participants of these interviews. 


\section{The Mission and Character of a Successful Recruiter}

One common aspiration shared by all the recruitment officers is a desire to draw as many "qualified" students as possible to WVU. My first interviewee was Brittany, an affable and outgoing admission counselor who is stationed in the New Jersey and Eastern Pennsylvania region. In Brittany's view, successful recruitment implies, meeting the academic needs of prospective clientele by availing them to possible major options. To her, WVU has been successful in making a large university such as this become personal to students by providing students with what she calls a "fit" that is the ability to match students up with their interests and aspirations. According to Brittany when students are placed in the right environment, they thrive academically; this is why the recruiter has to create a "connection" with the student. This connection has to be long lasting and most importantly strong so that any prospective student who is interested in WVU or has a need or concern will have "somebody they know that they can always call or email and they will be there." Brittany went on to say that recruiters have to be reliable and responsible when attending to the needs of students. There is also a non- negotiable need to follow up with students just in case they might need further assistance but are at a loss as to how to find it.

The resident recruiter for the Virginia and Washington D.C. area, Nancy, was of the view that successful recruitment of prospective clientele involves more than promoting WVU's academic programs. She described the recruiters' role as thus: "we are there to assist them as much as we can through the admissions process and help them reach their goals in education." The idea of matching up prospective students with academic experiences which resonate with their ambitions is paramount to a successful recruitment effort according to Felicia who recruits in "other states." In her view the recruiter's job goes beyond establishing a connection with 
prospective students - it also involves mastering the art of selective scrutiny. WVU, Felicia argued, is "not for everyone." In view of this, she pointed out, the overarching goal of drawing students to WVU has to be undertaken cautiously so as to attract the right kind of student whose aspirations resonate with the mission and poise of WVU. Recruiters, in Felicia's view, have to effectively interact with prospective clientele while skillfully identifying their unique needs. She stated that successful recruiters "interact with students and their families to determine what academic need they have and how WVU can meet that need."

According to Brittany, (recruiter for New Jersey and Eastern Pennsylvania) successful recruiting does not only involve a careful selection of prospective students, it behooves the recruiter to effectively market the university by making "prospective students visualize all the facts about the university" so they can "find out what they like, find out what they enjoy and then relate it to opportunities at the university." Luke, an admission counselor who recruits from New York and New England confirmed Brittany's idea about "painting the big picture" to students by saying that the goal of every recruiter is "advertising, it's all about advertising."

While reflecting pensively on the question of the recruitment center's mission, Gabrielle a recruiter in the West Virginia region spoke slowly on the issue of content mastery. In her view effective recruitment efforts start with a thorough grasp of the nature of the product being promoted. With a good knowledge base, any recruiter will be in a position to spark an interest in a student considering a particular institution for studies. She went on to say: "I can know everything about the engineering program, that is great but if the student is not interested in that, then it is fruitless." In other words the recruiters job goes beyond knowing about WVU -- it also involves a clear understanding of prospective clientele's background and disposition so the recruiter can provide them with the 'information they are looking for'. Nancy expressed a 
similar concern like Gabrielle's by saying that content mastery on the part of the recruiter was important because the students know when you are offering "fluff." She further comments:

“...You know you are going to run into so many different people um, students and parents and you know almost everybody has a different situation or different concerns so you have to be really approachable and you have to really know the school, do your research and um know what you are talking about. You have to be credible - people can tell you know if you are kind of BSing them..."

The last admissions counselor I spoke concerning this topic was Sandra, who recruits in Central and western Pennsylvania. Sandra has been on the job for nine years, and her passion about recruiting was written all over her face. She told me that the key to successful recruiting lies in the recruiter's "eagerness" to help students.

The importance of knowing the details about colleges, departments or the admissions process is not only for marketing reasons according Sandra. According to her parents of prospective first generation students need as much information to help them guide their children during the decision making process. In her view the admission process can be intimidating and by providing relevant and timely information, students can make informed choices.

Having asked the admission counselors about what ethical and philosophical underpinnings guided them during the recruitment process, I went on to find out from them how they effectively promote WVU to prospective students.

\section{Publicizing WVU}

West Virginia University is the flagship University of the State of West Virginia, however its clientele are drawn not only from its periphery but sometimes well beyond it. The 
diverse geographical backgrounds and demographics of the student body can partly attributed to the work of admissions counselors working from different pockets of the country promoting WVU to prospective students. All the recruitment officers were unanimous in telling me that they work mostly with prospective students and high school counselors. In most of these instances the parents of the students are also present at the recruitment meetings. Some of the publicity drives are also held during college fairs as well. They added that the Mountaineers Parents Club and the alumni also play a major role in recruitment efforts in most satellite recruitment centers. To help me find out the level of influence recruitment officers have on prospective students I asked them about what strategies they employ to attract students to WVU.

I started this segment of the interview with Sandra who is stationed in Pennsylvania. After attending to a couple of phone calls, Sandra paused for a few moments and then told me that tuition is a big selling point in her region. She normally starts her sales pitch by drawing a comparison between WVUs tuition costs and that of other schools in the region. Sandra also mentioned that she presents students with the university's wide array of majors while promoting and selling the reputation of the university's noted faculty and programs. When I asked her about the kinds of students she draws to WVU, Sandra told me that most of her clients show a high patronage for STEM programs (science, technology, engineering and math). According to Sandra, majors in Forensics, engineering, nursing, pharmacy, physical therapy, business and in some instances political science have gained patronage over the years in her recruitment region. Besides WVUs numerous college majors, Morgantown's unique topography, its urban appeal as well as its tourist attractions (outdoor sports) make it favorable to students.

Affordability was Nancy's key selling point as well. She explained that the students she in the Virginia - Washington D.C. area strongly consider WVU as a choice when tuition cost 
comparisons are made with local colleges or universities in the recruitment region. The distance between Morgantown and Virginia - Washington D.C. area is short enough for students who might want to make an occasional commute home. Nancy mentioned that besides tuition and proximity, majors such as Business, Engineering, Natural Resources and Forensics appealed readily to prospective students. Nancy added that alumni involvement in recruiting efforts and the prowess of the university's athletic teams also help in promoting the university. She further added that a campus tour practically convinces students when they see the topography of the place and its numerous landmarks (student's recreation center, public rapid transit (PRT) and outdoor sports).

Gabrielle told me that her recruitment area is unique because of West Virginia's reciprocity agreement with Ohio. The reciprocity agreement allows students from either state to pursue college degrees out of their home states at in state tuition rates. This arrangement is only for majors that are nonexistent in their home colleges and universities. For that reason WVU attracts students from rural settings in Ohio who are interested in agricultural majors not offered in their home states. Gabrielle also told me that WVUs notoriety in athletics and the popularity of outdoor sports like white water rafting, rock climbing and Morgantown's small city appeal also draws students to WVU. Besides majors listed on the reciprocity agreement, Gabrielle mentioned that majors like engineering, business, and some majors in the Eberly College of Arts and Sciences like music are also patronized. In instances where less popular majors are inquired about by a prospective student, Gabrielle says she "ups her game" a little to get students interested.

WVU offers a lot of college majors and Brittany says she makes it a point to advertise that to her students in New Jersey and Eastern Pennsylvania. She told me that our tuition costs 
are lower than the "in state" tuition rates in her region and that makes tuition costs a favorable selling point. Besides tuition, Brittany says she advertises programs that are "doing well" in WVU as well. As an aside, athletics also adds to the appeal for WVU as well as the surroundings. Brittany mentioned that school visits by prospective students have consistently drawn a lot of students to WVU. She said students get all the benefits of a large school but yet enjoy the benefits of a small school in the classroom setting. When I asked her about what colleges and or majors appeal to students mostly, she mentioned forensics, pharmacy, business, engineering and journalism. She was quick to add that other majors are also patronized though not on a frequent basis like the ones she mentioned.

“Opportunity and cost” were Felicia’s watch words for publicizing WVU to students in her region. She was adamant to point out any specific majors as selling points because she felt all majors attracted equal patronage. After prompting further, Felicia said that majors in engineering, forensics, liberal arts and the honors college attract most students in her region. She also mentioned Morgantown as a driving force for luring people to WVU. This is what she said concerning Morgantown:

"we like to talk about Morgantown being a small city which has the amenities found in larger cities, Like public transportation, um you know shopping, movies, arts you those sort of things but without the typical negative attributes of a larger city. Our crime rates are really low, transportation in town is easy, and we are somewhat sub urban - so those are the things that I think appeal to students."

Luke wasn't very forthcoming with responses when I asked him about the strategies he employs when publicizing WVU. He said however that the "large number of degree programs", 
the "inviting atmosphere" in the university and "division one athletics" are good selling points. He went on to say that the social environment in Morgantown and the wide array of outdoor activities available to residents also appeals to students as well. When I asked his perspective on what majors drew the most students to the university, Luke mentioned that majors such as forensics, business, engineering, nursing and journalism are high on the list of frequently requested majors. Having spent some time inquiring about their publicity strategies, I moved on to ask them about the challenges they face during recruitment drives.

\section{Challenges of the Recruitment effort}

The down turn in the economy makes it an uphill task when convincing students in Ohio to come to WVU. These were the words of Gabrielle, a recruiter in the Ohio region.

Tuition and fees for instate students in Ohio is much cheaper than what we offer, she said. Besides the cost of attendance, most high school graduates in Ohio have a strong allegiance to Ohio State University because of athletics and most of them will want to go there for that reason. Perhaps the one reason why they come to WVU is because of the reciprocity agreement which provides out of state students with instate tuition rates as well as an ability to enroll in programs which are not offered in their home states. Some students also defy cost and sports allegiances when they find programs here at WVU which resonate with their academic aspirations.

West Virginia has been stereotyped in the past and that picture of a rural setting is the perception some students hold in Sandra's region. Students in central and western Pennsylvania where Sandra recruits also have an image of WVU as a "party school." According to Sandra her presentations in recruitment settings do a lot to correct such misconceptions. She went on to say that she also stresses our proximity to the Pennsylvania border as well as affordability and 
academic offerings. Sandra went on to say that the decision to go to WVU also centers on a cost comparison process by parents as well as financial aid awards or scholarships. Sandra commented that the need for cost comparison of tuition and financial aid packages has come about as a result of economic hardships.

In Nancy's view, students in Virginia are harder to recruit because there are a lot of good schools in the area. The present economic setback has also caused a cross section of students to consider community colleges due to cost. According to Nancy, such students will normally transfer to four year colleges eventually. She was quick to add that WVU purposely reduced its freshman class for the 2008- 2009 academic year because of a record enrollment of 7000 freshmen in 2007. None the less Nancy was sure that the current economic downturn might impact $2009-2010$ admissions greatly.

Availability of funds is a major concern in Felicia's region. According to her, there are students in region who would have liked to attend WVU but are unable to attend because of financial constraints and an inability to meet scholarship merit criteria. In terms of the overall effects of the economic meltdown on recruitment, Felicia said her unit has carried out some research and is in the process of assessing the full economic impact with regards to recruitment. She conjectured that there is bound to be a possible reduction in numbers and nonresident students who find themselves in an economic quagmire might opt for in state colleges if their parents cannot afford the fees anymore.

In the New Jersey and Eastern Pennsylvania area, Brittany said that stereotypes about the region abound even though $99 \%$ of them are untrue. Her duty then is to try and correct those misconceptions. She was however hesitant to predict how the current economic downturn will affect recruitment drives in the future. 
In the New York and New England area, Luke mentioned that the image of WVU as a party school mars the school's reputation. Besides the ills of such stereotypes, most parents and students are also uneasy about the distance between their home states and Morgantown. Some also show concern about the cost of attending WVU besides the distance. Luke mentioned that the current reduction in freshman enrollment may be partly due to the economic downturn.

Having sought their views on the challenges of the recruitment process, I asked them to reflect on their own college major choices given the information they know about all the majors.

\section{Reminiscences about College Major choice - the Recruiter Perspective}

Brittany said she was not different from the students we see today, she changed majors a couple of times and then finally graduated with a Public Relations degree in 2008.

She said if she had all the knowledge she has now concerning college majors and corresponding job prospects, she will still have stuck with the major she graduated with.

Felicia says she has indeed learned a lot about the majors as a recruiter but wouldn't have changed her English and Political Science dual degree at the undergraduate level. She says she however got a Masters degree in Creative Marketing.

"Um, that is an excellent question" is how Nancy started her response to my question. She told me that once a while she thinks about that herself and probably thinks she would have changed her Public Relations major. She however got a minor in Business administration with a Masters in Business and Corporate Communications.

Sandra graduated with a degree in Hotel Management and Institutional Management but she hated her job as a result of work demands and her inability to spend time with her family. 
She said she enjoys her current job as a recruiter and she is very happy that she was able to transfer the skill sets from her old job to the new job setting. Sandra said she wouldn't have changed her old major given the information she has now because she enjoys helping people. The next segment of this segment is a synthesis of the interview report across all four themes.

\section{Interview Transcript Analysis}

The recruitment office plays an instrumental role in admissions at West Virginia University. My interviews with the recruitment counselors revealed an ardent commitment on their part to get prospective student clientele, the requisite information needed to make educated decisions regarding their academic careers. Almost all of them were in agreement that the cost of tuition in WVU was a strong selling point for promoting the university besides the appeal of the Morgantown area. Sports was also high on the list of factors that helped recruitment efforts though the schools unappreciated reputation as a party school as well as unsubstantiated stereotypes about the region hurt the recruitment effort. Besides fighting stereotypes, recruiters were also confronted with issues of distance between West Virginia University and prospect students' homes as well as the pangs of the current economic downturn.

Despite all these bottle necks, the recruitment office has seen an increase in enrollment as WVU registered a record enrollment of 7000 students in 2007. The disturbing trend however to me was the skewed nature of major preferences. All the recruiters adjudged majors such as forensics, business, pharmacy and engineering as the most patronized majors among students. They however made little or no mention of enrollment trends in the liberal arts majors although music, political science and journalism were mentioned in passing.

From unanimous comments made by recruitment officers I gathered that they saw their role purely as information agents who had no hand in a student's eventual choice of a college 
major. The recruiters' role was mainly that of pointing the students to information regarding their choices and also providing them with information about the regions cultural, social, economic and academic climate. There seemed however to be a stressing of the economic benefits (tuition) associated with choosing WVU rather than the wide array of academic programs. There was one respondent out of the interviewees who stressed academic possibilities over cost of attendance.

It became evident while I reviewed the interview transcripts that admission counselors did not play affective roles such as hand holding or leading students on to certain majors. However the skewed choice patterns towards certain majors like forensics, business and engineering as per the recruiting officers' comments made me wonder what sort of information students were given and what factors enticed them to go for such majors.

The recruiting officers did not go into detail as to what presentation styles they used or in what setting the information was given. It is probable considering the involvement of the parent club and alumni in certain recruitment settings that students whose parents, friends or neighbors pursued certain majors may have been influenced by the jobs or economic fluidity enjoyed by the alumni. This assertion if true may be what Bourdieu's (1990) theory of habitus posits. Students may have possibly been making decisions based on a family member, neighbor or friend's prior experience or input about one major or another.

It must also be mentioned that though the issue of tuition costs was a recurring theme in recruitment efforts none of the recruitment officers alluded to the idea of economic benefits postgraduation. That still leaves to uncertainty, the skewed nature of major selection by prospective students. None the less the recruitment offices' efforts are successful taking the enrollment numbers into consideration; however the answers to what drives prospective students to their 
major choices may well not lie within the confines of college recruitment as these interviews suggest. It is also very probable that the views of the six recruiters interviewed may be a minority opinion of the recruitment process as eight recruiters could not be reached after persistent attempts. The next segment of the paper is a document analysis of college brochures and view books with the aim of finding out if the answers to student college choice patterns lie within their pages.

\section{A Detailed Document Analysis of College Brochures}

College brochures are part of the toolkit admission counselors rely on during recruitment drives. A survey of college admission officials conducted by the Chronicle of higher education estimates that about twenty four percent of college and university budgets are spent on college brochures, view books and other recruitment literature (Hoover, 2008).

College brochures or view books for that matter are a way of selling a university or college's mission to prospective students. Often times, their messages showcase the mission, character and opportunities that abound in a prospective college or university. These brochures have thus become a brand name for the institution (Shampeny, 2003). What makes the marketing of colleges and universities quite elusive is that they sell an intangible product (Klassen, 2000). It is for this reason that college view books and brochures try to put a human face to their admission campaigns. Pictures of smiling students (Klassen, 2000), nicely mowed lawns, towering edifices of college campuses (Hartley and Morphew, 2008) and assurances of job placement are sure ways colleges and universities get their clientele's attention. Whereas the bigger and more prestigious colleges embark on recruitment campaigns using transcendental quotes, the smaller colleges and universities dwell more on the practical by assuring their prospective clientele of quicker graduation rates, a personable faculty and the prowess of their athletic teams. 
In view of current economic undercurrents, universities and colleges have had to decipher more effective and enticing ways of "wooing" their clients to their campuses (Cooper, 2009). In recent times there has been an influx of marketing corporations flooding the corridors of institutions of higher learning with different proposals aimed at helping institutions of higher learning appeal to their clientele (Hartley and Morphew, 2008). According to Cooper (2009), the yearning to reach a prospective student clientele these days will require a deviation from the formal approach to brochure and college book designing to include "colloquialisms" which represents youth culture in this day and age.

The importance attached to college brochures by colleges and universities partly stems from their patronage by a large pool of prospective students who go through a matrix of decision making processes meant to help them scout for schools that match their interests.

For these students, the availability of college brochures and view books help them digest the intricacies that characterize the college choice process (Hossler, Schmit, \& Vesper, 1999). In a survey examining the college decision making processes by post high school students, Hossler et al. stated that prospective students adjudged college recruitment material as a necessary element in the choice making process (p.107). This informs the reason why college and university admission counselors put premium on pamphlets, brochures and any literature targeted towards prospective students.

Though the literature on college brochures and yearbooks is not extensive, their relevance in college recruitment cannot be overlooked considering their continued usage and patronage by both universities and prospective students. The analysis of college brochures for the current study was meant to determine whether colleges and departments influence the college major selection process in any way. 
A content analysis was done on brochures from ten colleges namely: 1) Human Resources and Education, 2) Davis College of Agriculture, 3) School of Dentistry, 4) College of Law, 5) College of Creative Arts, 6) College of Business and Economics, 7) School of Medicine, 8) Perley Isaac Reed School of Journalism, 9) Eberly College of Arts and Sciences, and 10) the School of Pharmacy. The ensuing paragraphs are an analysis of core content sifted from the brochures and view books using the following themes: Establishing credibility, Community Service Outreach, Emotive Appeal, Technological Innovation, Aesthetic Presence, and last but not the least, Employment Possibilities. These themes were developed using Krippendorf's (2004) four stages of content document analysis (sampling, Unitizing, Reduction and Inference making) as a guide.

\section{Theme 1: Establishing credibility}

One recurring theme that runs through all the brochures I analyzed was a need to maintain a reputable image. All the college brochures reviewed were unanimous on the need to inform prospective students about their long standing academic achievements earned as a result of years of hard work. There was also repeated mention of meeting accreditation requirements. Such comments inadvertently inform students that the colleges they are considering are adjudged by their academic communities as competent, reputable and intellectually credible.

The College of Education described itself as a "national leader in the movement to renew programs." The brochure mentions that the college is accredited through the National Council for Accreditation of Teacher Education through 2011. The College of Arts and Sciences adopts a more personal approach in reaching its students. They try to make the collegiate experience personal by introducing prospective students their exceptional faculty. Mention is made of masterminds who have dabbled in the spheres of genome mapping and award winning students 
whose intellectual sojourns have sent them in different directions of the world. This rich academic resume portrays the college as a hub of intellectual vibrancy where young minds are groomed. The idea of grooming young minds resonates in the university's slogan which describes the university as a place "where greatness is learned." The department also makes mention of its distinguished Alumni, as well as its successes at grant acquisition and research all in the name of stressing the college's mission of academic excellence.

The College of Business also showcases its faculty's research innovations. Premium is placed on the colleges academic advising services and so mention is made of the college's receipt of a Golden Key National Honor Society Golden Apple award for excellence in academic advising. Prospective students are therefore assured of a personalized educational experience with a support network to help them make informed academic choices. The college's brochure mentions that the school is one of 551 institutions whose graduate and undergraduate business programs have received AASB international accreditation. They also have networks of intellectual collaboration in China, Germany, Italy, Poland, and the Czech Republic implying that the college is not only academically upbeat but also globally responsive and vibrant. Prospective students will thus study in a modern, diverse and culturally vibrant institution with global affiliations.

The School of Journalism makes mention of the placement of its alumni in top positions. The issue of accreditation is also readily mentioned. Disciplines in Journalism, Advertising and Public Relations have national recognition according to the brochure. As I mentioned earlier, the use of intellectual badges such as the mention of accreditation is meant to portray the college as an intellectual hub where students can have a tried and true collegiate experience. 
The School of Pharmacy also builds its prestige in the first paragraphs of their brochure. Their faculties receive "national awards" and their graduation rates "exceed 95 percent." Students who get into the program also have a total of seven student organizations to join while enjoying the department's partnership with reputable pharmaceutical industries some of which are local. They are also accredited through the Accreditation council for Pharmacy Education and have also won the university board of governors program of excellence award. Yet again the theme of excellence and research prowess comes to the fore.

The School of Medicine adopts no less an approach to lure its students. They boast of community service awards, 42 residency programs and a "high level of reaccreditation." They therefore portray an image of excellence to students. The stakes are "high" and students are challenged to attain a high level of discipline and dedication to the program.

Grant acquisition on the federal and private fronts has come easily for the Dental School. Their operations are also officially recognized by the Commission on Dental Accreditation. Their intellectual enterprise is thus credible and they are opening up new vistas of knowledge through cutting edge research.

The need to present students with a reputable image of the college is a common characteristic that runs through all the college brochures. There is the unmentioned belief that issues about accreditation, faculty reputations, successes chalked at grant acquisition and student involvement and excellence will either challenge or inspire prospective students to consider a college's academic offerings. I looked at the colleges' community service outreach next. 


\section{Theme 2: Community Service Outreach}

To help foster a good image, colleges and departments like to stress their involvement in community outreach and partnerships as per the brochures. Since the university is a land grant institution, it is not surprising that community outreach or "public good" (Labaree, 1997) efforts are patronized greatly. Such efforts enhance the prestige of the colleges while giving students a slice of real life experiences via internships where they can safely simulate theoretical experiences. The Benedum Collaborative in the education department has a long standing partnership with 28 public schools. The college's child development laboratory is also a community minded initiative where students and community members benefit from the services rendered. These initiatives inadvertently help the college meet a societal need through the provision of professional development services for practicing teachers while using the public schools as live training grounds for pre - service teachers.

The community initiatives undertaken by the Eberly College of Arts and Sciences cut across geographical lines. Faculty in the college have been involved in poverty research in Malawi, Africa while conducting cutting urge research on the possibilities of using trees in the production of Biofuel. They have also been involved in math education reform statewide and nationwide. These achievements have been carefully crafted in the front pages of the brochure to give a sense of responsiveness to community needs. It also gives the department an emotive appeal implying that they don't exist in isolation but rather work in concert with the community to sustain growth.

Community partnerships and professional development of business executives is how the Business College fulfills its community obligations. Their students are also involved in community partnerships which avail students to real life scenarios in the work environment. The 
college also boasts of a statewide business plan competition which affords winning teams a ten thousand dollar reward and "a package of business perks to help start a business." Faculty in the college's Bureau of Business and Economics Research provide the state's economic team with specialized input with regards to economic trends.

News reporting and documentary development in a community setting gives students in the Journalism school a way to give back to their communities. Students report for local newspapers and work with other regional broadcasting networks, providing a need while pursuing practicum and internships. The brochure mentions that the college and its students are involved in "cutting urge multimedia projects" one of which earned them an "Emmy Award winning documentary profiling cancer patients. Students in the college have also been involved with the creation of an interactive website which chronicles the stories of Hurricane Katrina evacuees." These humane efforts undertaken by the faculty and students certainly softens the heart of prospective students assuring them that they are going to be part of a public good effort aimed at making the world a better place.

The Dental School according to the brochure provides eighty percent of the dentists in the state of West Virginia making them an unavoidable community partner. They have also been involved with decision making processes in the American Dental Association and American Association of Orthodontics during several years of presidency on those boards. Their programs stress a community outreach obligation where dental and dental hygiene students "improve their clinical skills, learn about practice management, and experience service learning in West Virginia communities..."

The Medical School does not mince words with regards to their commitment to community outreach. In 2006 according to the brochure the college "received the prestigious 
Association of American Medical Colleges Outstanding Community Service Award.” They go on to say that this award "demonstrates the School of Medicine's commitment to its service mission and the citizens of West Virginia. The college is also highly ranked among the top schools with regards to rural health education.

Over sixty percent of pharmacists in West Virginia are graduates of the college of pharmacy. The commitment to meeting community needs has spanned over the last hundred years. The school has also embarked on continuing education drives for practicing pharmacists totaling 8, 0403 hours of continuing education. They also work in partnership with Medicaid in the Rational Drug Therapy Program while faculty participate in National Science foundation and National Institute of Health initiatives. This commitment to community service in my view certainly vouches for the reputation of the college. It can comfortably be argued that students coming into this major will yearn to be part of a program with a long standing history in community development.

The Law School keeps up its "public good image” (Labaree, 1997) by providing legal aid services to the public. It works in concert with community court officials to give its students a feel of what real life adjudication looks and feels like. Free legal aid is also provided for members of the community who cannot afford a lawyer. It can be deduced from the analysis of the college's community outreach efforts that the show of sensitivity and commitment is deemed a necessary element in developing a positive college image. The theme of emotive appeal is discussed next. 


\section{Theme 3: Emotive Appeal}

Given the importance of college brochures in the admission process for both colleges and prospective students, it is understandable why the contents of the brochures are carefully crafted to appeal to prospective students. Besides the need to assure students of a department's credibility and expertise, there is also a need to create a ,welcoming” atmosphere which is conducive for academic development. As the literature suggests, most colleges and universities try to assure students that the college experience provides opportunities for everyone regardless of their ethnic, economic or intellectual differences. There is the perception of an idealized environment where students have close relationship with faculty while enjoying a personalized academic experience. This segment examined how colleges appeal directly to prospective students in their bid to convince them that the college in question is the right place for them.

The College of Education writes that it offers its students an "academically supportive environment" where students can thrive academically. Its newly renovated buildings also have an "inviting" appeal to students according to the brochure. The College of Arts on the other hand was not so explicit about how they personalize the learning experience. Their students are brilliant, they win awards and they are also involved in "collaborative" research projects with faculty. It can be inferred that faculty foster a close relationship with students and are very attentive and responsive to their needs. Students in the department are also perceived as having high ambitions giving a sense that a lot is expected of new students too. There seems to be an assurance that new students can also be like the current students since the learning environment thrives on collaboration.

The Business College boasts of an award winning advising center which provides students with "caring attention and expertise." The advising office provides students with a 
tailored and personalized advising experience which sets students on a pedestal to succeed. The school also tries to match students with internships where they can experience real life business practices. There also seems to be an unspoken but implied promise that students will be "submerged" in a learning experience which will "roughen" them to navigate the tough world of business commerce.

Innovativeness, hands on learning and a personalized pedagogical experience are the hall mark of the School of Journalism according to the brochure. Students are self-driven and they have ownership of their learning experiences. They independently produce "real work-news stories, broadcasts, campaigns and projects." Students also "work side - by - side with award winning faculty" alluding to the notion of a personalized and supportive learning experience. Students are also said to enjoy an "intimate, small school environment." There is the presupposition that prospective students will enjoy studying in a collaborative environment which exposes them to both theoretical and practical experiences.

The Pharmacy School does not make any explicit mention of how it treats its students. I noticed that the college's faculty had been described as an "award winning" team. Students also have to apply for "competitive" scholarships. This means there is a need to maintain a competitive urge right from the onset to be successful. The Pharmacy School comes across as a bit snobbish and not alluring as the other departments are partly because there are used to seeing a large pool of applicants and students who express an interest in the major know the implications of the choice from their freshman year. Students who make it into the program however receive personalized help, they have access to class lectures online and also benefit from community residence programs. All said and done the onus rests on the student to prove him or herself as capable of thriving throughout this academic endeavor. 
When I reviewed the School of Medicine brochure, there were no direct comments regarding student welfare. They however made mention of a hands on, practical learning experience. Students have options to study with "medical professionals" depending on what specialties they are heading towards. Student lectures are archived online to ensure easy access to class materials anywhere. There seems to a foreboding that despite the stern academic expectations and rigid curriculum, students will be comfortably placed to succeed because of faculty and peer support as well as exposure to community based internships.

Tuition costs are always a concern in this day and age of economic hardship and the dental school makes sure that its students receive financial help. The school also adopts a community based learning approach which combines theoretical learning with a service learning component where students are involved in clinical work. The school is also very accepting of students from all ethnic, racial, or socioeconomic backgrounds and they take steps to create a supportive environment for all their students. Students, the brochure mentions, have the "opportunity" to "improve their clinical skills."

The College of Law believes in promoting diversity in a bid to create a level playing field for all students. They describe the learning environment in their school as "supportive." The college's faculties "take pride in being accessible to students and the public." The presupposition is that students will feel welcome in a prestigious program, with excellent faculty involved in innovative academic work and community outreach.

The warm embrace effect as per this paper refers to the efforts made by colleges and their faculty to make the collegiate experience an easy and comfortable transition for new students. Prospective students are assured of a support network when they enroll. This assurance seems to reverberate in one way or the other in all the college brochures reviewed. Some recurring 
themes were "personalized instruction", as well as internships and partnerships with faculty. The next segment looks at how colleges use technology as one of their selling points.

\section{Theme 4: Technological Innovation}

Technological innovations have overtaken us all by storm. The presence and increasing availability of internet access is making online schooling a viable option. Communication and advertisement of college majors has taken on a new dimension with the influx of technological savvy students. In some institutions, virtual tours are used as a way of attracting prospective students to university campuses. It has therefore become imperative for colleges and universities to send their message via a medium that appeals to and readily catches the attention of their clientele. By alluding to the use or existence of technology in pedagogical endeavors as well as research, colleges and universities show prospective students that they are abreast with the newest innovations in research and teaching. Students are also promised an educational experience which is enriching and convenient as a result of the infusion of technological innovations.

The College of Education says it has the "latest educational technology." These technological innovations according to the college are sensitive to the needs of students with disabilities as well. The college also offers online courses as they try to reach a wider student audience. The Speech Pathology and audiology department which is housed in the college also has a new state of the art listening booth which enhances student learning and patient treatment.

The College of Arts and Sciences does not dwell on the issue of technology very much, the brochure however makes mention of an "automated finger print identification system in its forensic and investigative science program. Students in that program according to the brochure 
enjoy working with award winning faculty in a personalized, supportive environment which is technology driven.

The School of Business School on the other hand barely touches on the role technology plays in its undergraduate programs. They however state that their graduate programs are "highly focused on technology." I safely deduce that students in the management information systems program might possibly be introduced to a slew of technology during their academic experience though the brochure did not mention that. The college as per the brochure concentrated more on the academic prowess of the school and its global affiliations rather than the use of technology as it relates to teaching or research.

In the Journalism School, students are prepared for "careers in the $21^{\text {st }}$ century using the latest technology." They navigate real life experiences using "cutting edge multimedia projects. The curriculum strikes a balance between hands on experiences and community based internships which effectively prepare students for the job market. Thus prospective students will be working with faculty who use the latest technologies in the field for research and community outreach activities. Students will therefore enjoy a vibrant learning environment which promises excitement by way of classroom experiences and internships.

The Law School assures its prospective students of easily accessible wireless internet connectivity. The college also has distance learning facilities as well as video conferencing technology. Students can therefore take their laptops to class, the library or the student lounge and still have internet connectivity. The college thus recognizes the need to use technological devices to improve the collegiate experience. 
The Dental School also incorporates technology in its pedagogical activities. The school promises its students "a state of the art computer information system" which "facilitates the management of clinical programs efficiently" and also "improves the educational experience for students." The school of medicine is involved in cutting edge biomedical research and records of students in the college are managed using an "advanced media link." Students can also have access to college lectures online via the use of Camtasia software which helps capture video and audio using screen capturing software.

The technology climate today demands that every institution or individual for that matter keeps up with new innovations in the field of technology partly because of the need to boost efficiency and also keep up with the competition as it were. It is therefore understandable why colleges reviewed in the brochure were making mention of technological innovations. The bid to showcase technological innovations is given credence by virtue of its appeal to the current crop of students applying to go to the university. For these students and for the society as a whole technological device has become a way of life, a necessity rather than a luxury. The next section looks at how colleges promote their structural edifices as a way of promoting their teaching, research and recruitment agendas.

\section{Theme 5: Aesthetic Presence}

In all the college brochures I reviewed, I noticed that every college made mention of the construction or renovation of buildings. These facilities were either "newly remodeled" as in the case of the Pharmacy school or newly built state - of the -art edifices as in the case of the colleges of medicine and dentistry. The College of Arts and sciences did mention that its halls have undergone "extensive renovations" while the college of education writes about improvements in twelve classrooms with a "redesigned front entrance." The journalism school in 
meeting its vision of $21^{\text {st }}$ century education has "new" computer labs, a multimedia studio and digital editing suites. Neither the college of Law nor the business school made any mention of building renovations or construction.

The writing about structural edifices though seemingly far removed from an intellectual enterprise helps in painting an all-round picture to prospective students. The colleges thus present their research achievements, showcase their faculty's innovations and then talk about how a combination of their resources and brains can make prospective students have the best possible intellectual experiences. The last theme in this analysis looked at how colleges attract students by alluding to the economic prospects of getting a college degree.

\section{Theme 6: Employment Possibilities}

One of the main arguments this paper has advanced is how capitalism has dealt a blow on educational choice and decision making. As the world recovers from the grueling effects of the economic downturn worldwide, the urge to settle on an educational endeavor with the propensity to reap economically reward dividend has become enticing. It is for this reason that college brochures and for that matter the current theme under review "Economic possibilities" was examined. The aim of this analysis was to scout out for any comments or visual representations that seemed to suggest or refer to economic advancement in any way.

The School of Journalism was not up front about its efforts to help graduates secure jobs. They stressed a vocational styled pedagogy which is heavy on practical experiences. Student projects are of a quality that is deliverable to real clientele and their graduates work in "top news organizations and communication agencies around the world." Thus students who go to the 
journalism school supposedly stand a high chance of landing jobs in prestigious settings which reward them appreciably.

The College of Human Resources which houses the Education and Speech Pathology departments is equipped with a Job accommodation network which "provides free consulting services" on job searches and interview techniques. The Law School makes more exact statements about jobs by stating in numerical terms that they have a 95.2 percent job placement record which normally happens barely nine months after graduation. They go on to say that graduates from the college "earn top salaries" at law firms throughout the United States and worldwide.

The School of Business acknowledges that the job hunt process is "important" to students, parents so they do well to facilitate student employment post-graduation. This is done by bringing recruiters to the door step of the college to make the job search process easier. The center also houses a Center for Career Development "which offers professional development courses" which help students develop interviewing, business etiquette and resume writing skills.

The Pharmacy, Dental and Medical school brochures do not mention any thing about job placement, prospects or remuneration. They do mention that a number of their graduates hold or have held presidencies in discipline related associations. The Pharmacy and Dental schools assert that most of their graduates are employed in the state. The College of Arts and Sciences was also quite about employment prospects but mentioned a number of alumni who have prestigious jobs. I assume since the college is huge and it encompasses a lot of majors, listing job prospects will be a complex task.

The analysis of college brochures helped define and delineate the nature of college brochures and the roles they play in college recruitment efforts. It is evident that Labaree"s (1997) 
three step description of the philosophical goals of institutions namely democratic equality, social efficiency and social mobility closely match the character of the college brochures analyzed. It is as if all the colleges and schools for that matter made these brochures in concert and covered all the themes discussed in this analysis. It stands to reason I reckon that all the colleges believe that prestige, the portrayal of personalized curriculum, technological innovation, the mention of structural edifices and or with the promise of jobs are necessary ingredients in luring students to grace their hallways. The next section examines college view books which encompass the use of visuals and quotes as a way of recruiting students.

\section{College View books}

I went on further to examine three college view books which featured the college of creative arts, engineering and then the University as a whole. College view book analyses were also done along the lines of the themes used in the college brochure analyses. The themes were: Establishing credibility, Community Service Outreach, Emotive Appeal, Technological Innovation, Aesthetic Presence, and Employment Possibilities. These themes were developed based on Labaree's (1997) analysis of the educational philosophies of educational institutions which are: social efficiency, social mobility and democratic equality. These view books were reviewed both textually and visually to ascertain how they impact student recruitment.

The College of Engineering's view book is a colorful catalogue of majors, faculty and students. The use of unusual fonts, colors and glossy pictures help portray educational experiences steeped in excellence, fun and mystery. According to the dean of the college, he and his colleagues have "created an exciting learning environment." He goes on to say: "We have talented faculty who are experts in their field, the latest technology and excellent facilities for education and research. Come and visit and see for yourself." The college thus bases its sales pitch on the institutions 
prestige. The quote from the dean is embedded in a dark background flanked by a purview of the beautifully lit skyline of the Evansdale campus. Students are thus availed to what would be an exciting campus where intellectuality is nurtured.

In the spirit of community building the college view book unfurls its character to prospective students by calling on them to join in the quest to cure cancer, create eco- friendly power sources or do an unimaginable deed such as building a canoe with concrete. The possibilities are thus presented as endless. There is a sense of a community outreach- marrying academic excellence with a need to heed to humanitarian needs. The view book showcases some students in a relaxed posture enjoying the summer weather while other students are lost deep in intellectual thought sampling colored liquids in beakers. The smiles on the students' faces and their poses in colored summer t-shirts supposedly melts the intimidation associated with meeting the college's entry requirements or overcoming academic challenges. Students are pictured working hand in hand with faculty in laid back environments with sophisticated equipment featuring in the background. There is thus a presupposition that a "friendly family atmosphere exists to ensure students' success."

The students who grace the pages of the brochure are presented as intellectually smart and all rounded. They engage in extracurricular activities such as car racing, soccer and ballet. A student is pictured balancing from a gymnastic beam enforcing the need for balance in the college environment. Technology innovations resonate from every inch of the glossy view book. On the front cover, a couple of delighted students are working on motorized robots. Students are also engaged in novel experiments in cancer research, eco-friendly fuels and floatation.

In terms of economic fluidity, the engineering college says explicitly that this whole collegiate experience is centered on "getting a job." Career fairs organized by the department draws 
in over hundred employers and graduates end up with "great jobs" working in prestigious places like NASA, Microsoft, Bayer and a lot of other places.

The view book presents college as a fun place, devoid of suffering, frustration, dejection or intimidation. Students are bound to enjoy every bit of the intellectual or social elements that punctuate the learning experience. All said and done, students are assured of guaranteed jobs which are economically rewarding.

The College of Creative Arts throws the spotlight on their students. A caption on the view book reads: "It's all about you." The college makes a promise to its prospective students that they will experience hands on learning initiated by faculty who are passionate about teaching. Classes are described as "interwoven and interdependent" celebrating and encouraging student academic efforts. The spirit of self-centeredness also rests on this brochure as it was designed by students for students. There is not much said about structural edifices nor prestige save the fact that faculty are passionate. Student attestations to faculty competence are enveloped in student comments such as this: "one of the things I appreciated most... is that the program was so specific and focused. I had a chance to work closely with my professors and I really learned a lot from them.” The college also boasts of "intimate classes, one on one instruction, and a close community of friends."'The view book is silent about the structures it is housed in and no mention is made about technology use or innovations in that regard. No allusion is made to job acquisition or prospects, however community partnerships and outreach seems prevalent.

The last view book I examined was one on the whole university, very brief (considering the size of the university) but yet symbolic as it portrayed the spirit, character and mission of the university as a haven for learning, experimentation and building social, cultural, academic and economic relationships. The front cover invites prospective students to a world of opportunities 
spanning geographical boundaries and cultures. As the foreword states, "a college education challenges your perspective, opens doors, expands your world view..." The idea of the university "being a door" to a world of opportunities, indirectly draws in the idea of economic and intellectual fulfillment. As one of the graduates of the university writes, "It was here where my eyes were truly opened to the world... these are experiences I couldn't have gotten anywhere else." The university is thus fulfilling students' dreams, affording them a lifetime of opportunities born out of an educational experiences accepting of ethnic, cultural and social preferences. Students explore the university experience not only by taking classes; they can also leap into nature's wild beauty through kayaking, hiking or digging up fossils.

The university flaunts its prestige by highlighting scholarships and awards earned by its staff. Mention is also made of other achievements such as a top ten ranking for rural medicine, national merit scholarships and a growing presence of international students all pointing to an impressive patch work of achievements. The university's outreach to prospective students has been virtualized. The brochure lists the university's representation on "you tube", "Itunes", "Facebook", "Widgets" and "blogs." These are sure ways of capturing the heart and attention of the present generation of students as this resonates with their lifestyles. The technological revolution not only takes place on the internet, the school has computerized emergency alert boots to ensure students' safety.

Amidst the portrayal of academic excellence of faculty and staff in the fields of astrophysics to the controversies in philosophy, the prospective college degree is described as an "investment" which makes good on its promise of appreciable returns. As one student put it "WVU provided me with enough financial aid and a scholarship to keep me out of debt... when I say WVU, the first thing that comes to my mind is success." Students are promised employment opportunities through the career services center. 
Students pictured in the view book seem elated, successful and on top of the world. College is thus a happy place where students "grow", "discover new ideas" and: see beyond the classroom" as they savor the beauty of diversity and a true exchange of ideas. Students are urged to go see the world by striding the streets of Peru, Russia, Malawi, Chile, Dubai and even the heart of the Appalachian Mountains. An appeal is made to students to "keep both sides of their brain happy by exploring minors and taking "intellectual risks. This is possibly the only true appeal the brochure makes about the college experience beyond the portrayal of college as a blissful experience. The idea of taking risk makes the collegiate experience real considering that it is an "investment" which requires a favorable outcome. The odds are always favorable according the brochure; you can be as successful as any school alumni who find him or herself in a managerial position at a prestigious multinational company. Students potentially stand a chance of having their picture placed in a university brochure with a reassuring smile which will motivate other curious freshmen wanting to explore their potential.

The brochures and view books sum up the collegiate experience in a matter of minutes, initiating students to college life through the alleys of college admission requirements, state of the art edifices, reputable faculty, student life right down to what seems to matter most, jobs. If college is an investment then the use of marketing strategies in the design of university brochures finds relevance. Though intellectual fulfillment seemingly erodes any allusion to job advancement, all the college brochures subtly use economic propensity as bait to assure students that their investment is safe and promising. A state of the art classroom, , a Truman scholar or the latest breakthrough in biometrics are sure ways to sell the institution but more importantly the idea of service, community outreach and preparing students to actively participate in the body politic of their communities is certainly fulfilling and novel in so many ways. This sense of 
fulfillment vividly manifests in the unchanging smiles and perceptions of students and faculty etched in between the pages of the view books and brochures. 


\section{Chapter V: Discussions}

The college major choice process as per the literature is a multi-faceted one (Beggs, Bantham \& Taylor, 2008; Montmarquette, Cannings \& Mahseredjian, 1997). The decision to choose one college major over another is driven by so many factors such as intrinsic interest, family or peer influence, college brochures or college recruitment. According to DeMarie and Aloise-Young (2003) and Berger (1988a) intrinsic interest played an immense role in student selection of college majors. This assertion held true for the current research, however it must be reiterated that a multiplicity of factors, a notable one being a student's socio-cultural background can punctuate the decision making process (Bourdieu, 1990). As the current research deduced from college recruiter interviews, environmental factors such as the geographical location of a college or college tuition rates has the tendency to sway major selection options. Discussions of the study results will be done in relation to the overarching research questions as was done in Chapter 4. These questions are:

R.Q.1) How does the prospect of financially rewarding jobs influence the major selection process by freshmen and sophomores at West Virginia University?

R.Q.2) To what extent does a student's family influence the college major choice process?

R.Q. 3) To what extent does a student's friends or peers influence the college major choice process?

R.Q.4) To what extent does a student's interest in a major affect the college major selection process? 


\section{Analysis of Research Question One}

Research question one examined the prospect of financially rewarding jobs and how that influences major choices by freshmen and sophomores in the university. The literature on college major choices suggest that economic utility or the financial viability of a major determines to some extent a student's college major choice (Berger, 1988b;Thomas and Zhang 2005). The current study revealed that $72.8 \%$ of survey respondents did in fact consider financial rewards of their majors post-graduation before settling for it. ${ }^{34}$ Student responses varied however in terms of how much thought they gave to the phenomenon. A little over $21 \%$ of the students based their choices on a major's financial reward in the future while $29.6 \%$ of them said they tilted their judgment quite a bit due to financial viability of the prospective major. About $21.7 \%$ said their decisions were somewhat influenced by post - graduation financial prospects attributed to their major choice. It is however telling that $72.8 \%$ of students based their college major decisions on the prospective major's economic prospects. Interview transcripts from college recruitment officers revealed a skewed patronage for majors with traditional economic promise such as Forensics, Pharmacy, Business, Engineering and Journalism, Engineering, and Forensics, though a cross section of students requested majors from the College of Liberal arts. This pattern of college major selection may be so because students give high consideration to career advancement and job opportunities when deciding on their college majors (Malgwi, Howe \& Burnaby, 2005).

\footnotetext{
34 These percentages are based on student responses to Likert item three (Financial reward in the future) on question 10 of the survey.
} 
Prospects of job advancement post-graduation influenced the college major selection of $88.7 \%$ of students on varying levels ${ }^{35}$. Of this number, $21.6 \%$ of students relied heavily on job advancement prospects when making their choice. About $35.3 \%$ of the respondents said they gave quite a bit of thought to the idea of job advancement while that was somewhat the case for $23.4 \%$ of the respondents. The phenomenon was insignificant in the case of about $8.4 \%$ of the students. College brochure analyses revealed a partial reinforcement of the college - job relationship by the colleges in the university. The advertisement of statements such as "it's all about jobs" may inadvertently fixate the thoughts of students on post-graduation job prospects. Other possible factors that influenced college major choices may well be attributed to the efforts of alumni and the parents club of the university who work in concert with college recruitment officers. The featuring of past alumni in respectable jobs and the role played by the alumni in recruitment efforts as per recruiting officers may thus influence a student's academic aspirations.

Job security ${ }^{36}$ also mattered for $91.2 \%$ of student respondents though the levels of consideration varied. The thought of having a stable job post-graduation heavily impacted the college major choices of $23.5 \%$ of students who took the survey. Thirty percent of the students said they considered the thought of job security quite a bit though other factors played a role as well. For $20.9 \%$ of the students the response to the question was somewhat again citing a combination of other factors playing a role in their eventual major choice. For $13.9 \%$ of survey respondents, job security was insignificant in terms of deciding on a prospective major. Despite scattered student perceptions with regards to job security and the superimposing theme of

\footnotetext{
${ }^{35}$ The percentages reported represent student responses for the likert scale in question 11 . The gradations were " $5=\mathrm{A}$ great extent, $4=$ Much, $3=$ somewhat, $2=$ little, and $1=$ Never. The data being discussed was item number 3 on the lists of factors which purportedly influenced students to choose their current majors.

${ }^{36}$ Job security was item number 5 on the list of factors for question 11. Please refer to Appendix G for clarification
} 
economic utility, there still exists a reliance on economic indicators during decision making. This can be arguably justified by the fact that students are making huge financial investments in their college career, a majority of which is vested in loans which have to be repaid.

During the interviews with college recruiters they indicated that alumni and the parents club of WVU help them immensely during recruitment drives. It is probable that some students may be picking up cues when alumni recount their college experiences and their current experiences in the work environment. When students were asked about how a living testimony ${ }^{37}$ from someone working in a field similar to their major impacted their current major choice, $21.6 \%$ said their major choice reflected that line of thought. A total of $66.1 \%$ of the respondents acknowledged that evidence about the work environment played a role in their choice. These perceptions yet again were scattered along a continuum which ranged from "much", "somewhat" to a "little." Though the individual percentages for "much", "somewhat" and "little" were low, the collapsed percentages show a patronage for work environment evidence to aid in the major choice process.

Investment in a college major today involves a lot of money. Most students pay for their college education by securing financial aid subsidized and unsubsidized loans and in rare instances grants and scholarships. A notable scholarship among West Virginia residents is the Promise scholarship which pays for four years of a recipient's undergraduate degree. It became evident as per the results from the survey that freshmen and sophomores, who were the focus of this study, ruled out the notion of college tuition pay back obligations when choosing their majors. Hence such students did not select majors on account of tuition cost.

\footnotetext{
${ }^{37}$ The percentages reported here are for item 4 (assurance of future success in chosen major from someone working in a similar field) on the lists of factors that influence a student's choice of a college major found on question 13 of the survey.
} 
About $71.8 \%$ of the survey respondents stated that they ruled out the thought of loan pay back obligations when they chose their college majors. There was however a cross- section of students $(27.2 \%)$ who seriously considered loan pay back obligations before making that choice. That being said, it is possible that a student's socioeconomic status and the sources of financial support available to him or her might influence the answers given to any question about the correlation between tuition fees and college major choices. A review of student responses to the question on college funding sources revealed that $26 \%$ of them took loans while a total of $87.5 \%$ received college funding from sources with no pay back obligations. Funding sources ranged from grants, scholarship, parents right down to "self" which can be translated into the students own efforts. In the yes or no segment of the survey, students were asked if tuition affected their major choices and $68.2 \%$ of the students said no. Influence of scholarship awards on major choices also hovered around the thirty- ninth percentile confirming that college costs were not a determinant for college major choice. Question two examined the effect a student's family may have on the college major choice process.

\section{Analysis for Research Question Two}

Research question two examined whether families play a substantial role in determining the direction of college major selection. The occupational backgrounds of parents as per the literature on familial influences impacts students' eventual major choice (Douvan, 1976; Lepel 2007). As Bourdieu (1990) opines we are often times influenced either inadvertently or consciously by our socio-cultural backgrounds which then direct our thought process or perceptions.

When students were asked what their parent's reaction would be if they changed their majors, $59.6 \%$ of students said their parents will support them fully. About $15 \%$ of the students 
said their parents will check the marketability of the new major while $19.8 \%$ of respondents mentioned that their parents will leave them to decide. There were some students $(5.2 \%)$ who mentioned that their parents will vehemently oppose their major choices if the new major did not appeal to them. It therefore follows that about $20 \%$ of students made their major choices with significant interference from their parents. It is in place to say that parents may still have vested interests in the education of their children.

The survey revealed that $47.4 \%$ of students were in no way influenced by familial obligations when they chose their majors. However $52.6 \%{ }^{38}$ of the students indicated that their major choices had been influenced by the thought of fulfilling family obligations which could mean staying in a particular major because of parental approval or even wanting to be like a member of the family who has been successful in a particular line of work. About $83.2 \%{ }^{39}$ of students said they heeded to suggestions made by their parents and siblings during the major selection process while $16.8 \%$ of students did not factor in such suggestions when making their choices. Given that the populations of students advised at our unit includes non - traditional students some of who happen to be parents, it came as no surprise that some students ruled out familial support of this kind. Despite the seeming insignificance of student responses with regards to familial influence, a combination of answer choices which connote any allusion of allegiance to family obligations no matter how small revealed that a great majority of students strongly considered their families as partners in the college major decision making process. As

\footnotetext{
${ }^{38}$ The $52 \%$ stated here is a combination of the scores who students who chose either "a great extent", "quite a bit", "somewhat" and "little" for item five on question number ten. This excludes the percentages for "not at all" which was $47.4 \%$.

${ }^{39}$ The $82.2 \%$ is a tally of scores for "a great extent", "much", "somewhat" and "little" for item 3 (Suggestions from parents or siblings) on question 13.
} 
Corcoran and Courant (1985) point out, the sort of households students find themselves in determine to a large extent the kind of majors they chose.

\section{Analysis of Research Question Three}

Peer influence plays an important part in student decision making from high school to the collegiate setting. The level of influence could range from academic decision making as in choosing a major or even selecting a field of specialization within a major (McDill\& Coleman, 1965; Arcidiaconoa \& Nicholson, 2005). When students were asked if they considered advice or input from friends or peers when choosing their college majors, the responses varied greatly from not all to a great extent. After taking out the cross section of students who ruled out peer support in the major selection process and combining the scores of students who selected "a great extent", "quite a bit", "somewhat", and a "little" the effect of peer influence in determining students' eventual major choices was significant averaging about $61 \%$ as opposed to $38.9 \%$ of students for whom peer input was insignificant in their college major choice. Thus students are still in some shape or form still considering input from their peers during the decision making process. Research has indicated though that student college major decisions are sometimes tied to taking introductory classes (Berger, 1988). Student responses in this survey also point to a self-driven resolve in the pursuance of a college major. Almost all the respondents $(91.9 \%)$ were unanimous in professing a "can do" attitude if their friends and family gave no feedback at all concerning their majors. Recruiting officers also pointed out that they do not lead students to any particular majors as rather they mainly offer the universities major classifications. It is interesting to note however that when students were asked if their upbringing in terms of their social networks of family and friends impacted the direction of their college career, $81.9 \%$ of the respondents answered in the affirmative confirming the need for a kind of support system. This 
could also mean that the presence of alumni and the parents clubs of the university during recruitment drives as per recruiting officer's comments may be influential in the major selection process by prospective students. As Lyle (2007) posits peer influence was not strongly influential in the college choice process, as rather it was seen in cohort settings which can be academic or social.

\section{Analysis of Research Question Four}

Research questions one through three examined the extent to which a student's college major choice is affected by the following factors: financially rewarding jobs, family, and or peers. Question four examined the extent to which a student's college major choice was impelled by intrinsic interest. Three questions related to intrinsic interest were embedded in question 10 , 11 and 13. Ninety percent ${ }^{40}$ of students acknowledged in question ten that they were influenced on different levels by their intrinsic interest in their major of choice. When students were queried about the same phenomenon in survey question 11, the combined responses from all Likert scale gradations averaged a little above the ninetieth percentile yet again. Combined percentage scores for student responses to the intrinsic interest item in question thirteen averaged about $96.3 \%$ indicating that students exhibited differing levels of passion for their major choices. The total percentages for students who were greatly influenced by their passion for their major in questions 10,11 and 13 were $32.8 \%, 33.3 \% 45.3 \%$ respectfully. The percentages of students who completely ruled out intrinsic interest in questions 10,11 and 13 were $10 \%, 8.7 \%$ and $3.7 \%$ respectfully. This goes to show that there were more students who chose majors because of an innate desire to pursue the chosen academic path. This point seems to corroborate

\footnotetext{
40 This percentile is a total of students' perceptions about the relationship between intrinsic interest and college major choice. The reported percentage includes all students responses for the Likert scale gradations: "a great extent", "quite a bit", "somewhat" and "little".
} 
the assertions of recruitment officers that they played no role in pointing students to the majors that they eventually settled for.

The theme of college tuition costs was revisited in question 18. Students were asked if they will consider a major change if they were awarded a college scholarship. This question was meant to see if there was any relationship between tuition and college major choice. As can be recounted in earlier analysis on the subject the correlation was weak and virtually nonexistent. This line of thought did not change much in question 18 , about $59 \%$ of students said their major choices will not change compared to $40.2 \%$ of the students who felt that a major change will be evident given the new circumstance.

The attempt at understanding student college choice patterns doesn't come easily with ready answers as the process is fraught with complexities. The survey responses did not point readily to either economic utility (students' projection of financial reward post-graduation) or family or peer influence though intrinsic interest percentiles were much more substantial without a collapsing of scores.

It is however mentally unnerving to me considering the skewed nature of college major selections for students who took the survey. As can be recalled there was a heavy concentration of majors in the sciences, business and engineering. The answers for that may well lay in the fact that the surveys were administered in Sociology 105 classrooms but yet still students in different disciplines can take Sociology 105 to fulfill general elective requirements for their majors.

Speculating from the standpoint of a participant observer in the current research, I bring to bear my experiences at the advising center pertaining to student's inclinations to selecting majors. The process is normally as I recall fraught with questions about easy classes to take to 
meet departmental requirements to become full majors since most of the students advised in the undergraduate advising center are normally designated as pre - majors till they hit junior status or fulfill certain GPA or test score requirements. There is resort to using "rate my professor" websites to scout for "easy" professors and there have been countless number of times when money has come up as a determinant of what major path is pursued. As can be recalled $80.9 \%$ of students said that future remuneration had an effect on what major choices they pursued and 83.5 $\%$ of students were in favor of designing their own major curriculum if they were given the chance.

Given the role recruiting officers play in garnering student interest in the university and also recalling the role played by alumni and the parents club, there is reason to believe that major choice patterns may be subtly influenced. The demeanor of departments as evidenced in their brochures and view books may also unconsciously send unconscious messages of economic promise associated with a major to students. There is of course evidence from recruiting officers that students from the east coast of the nation and other out of state areas choose the university mainly because tuition costs are cheaper. There are also some students who choose the university because of the prowess of its sports teams or even because of the state's pristine and gorgeous waterways.

\section{Implications}

The founding treatise which propelled this research was the influence of market economies on our way of life. The affliction with grades and the emergence of a market centered culture in higher education was recounted (Zemsky et al., 2005). But as the current data suggests students are their "own" persons and they know what they want and how to get it. There however was resounding evidence albeit scattered, that student still initiated their major choice endeavors while testing the tempo of job market potentials pre and post-graduation. This thought process 
involved a consideration of future remuneration in the job market; analyzing evidence of economic fluidity from people in the work place, and seeking parental and peer input among others to help negotiate their college aspirations. The skewed distribution of majors in the current research towards majors with economic promise and the patronage of such majors in recruitment circles lead me to assume that there is still a learned helplessness which tends to bracket the choice patterns of students using economic parameters as a yardstick. In Freire's (1973) view such perceptions generate a learned helplessness which makes us comfortable with the status quo. The glorification of grades, grade point averages and attendant rote learning habits ingrain in students a line of thinking where learning becomes an outlet to economic salvation and not intellectual enlightenment. Thus when the engineering department brochures says that it's all about getting a job, students chew relentlessly on the promise of grades at the expense of an intellectual experience.

The choice of a college major is just one test out of many choice processes which readily manifest our servitude in the industrialized world. Beyond the phenomenon of major choice lies the students journey to acquire a college degree and as I am privy to the process there are students who nurse such lofty thoughts of getting into a certain major only to realize that their intrinsic desires was a charade fed by pressures from family, friends or the promise of the market. My arguments are not meant to condemn the results that the study has revealed, as rather it is to draw attention to the elusive and almost clouded nature of economic oppression. As Freire (1973) points out, the only way to diffuse oppression is for the oppressed and their revolutionaries which will be adherents of free intellectual thought to untangle the facets of oppressions from a multidimensional viewpoint encompassing social, cultural, ethnic, economic and political viewpoints. Our societies and schools are still entangled in a capitalist mindset 
which punctuates societal norms, individual preferences or even the direction of our destinies (Giroux, 1988). The fact remains as per this research that a majority of students are still holding on to economic possibilities of jobs and or remuneration as they embark on their intellectual journeys. The market is thus acting as a pivot on which educational decisions or intellectual experiences revolve. We have still not left the mashes of vocational styled educational agendas which according to Shapiro (1988) render our schools "training grounds for jobs. There is still the need to press for a resistance against capitalist ideology and wean students off the heavy reliance on economic propensities as opposed to the possible vistas of intellectual enlightenment. According to Freire (1973) we have to savor our relationship with the oppressor which in this case is the market economy and determine what "false generosities" it throws our way. A sure way to derail this learned helplessness that afflicts us is to deconstruct the complexities of the market economy so as to reverse its hold on our very existence. College campuses have to initiate a critical conversation which rakes through layered histories which define the collegiate experience. The conversation has to include the debate about college enrollment, competencies and the strategies employed in college recruitment. The market should not control the educational enterprise; the opposite should be the case.

Retention efforts have to travel the spiral of poverty as it relates to college costs and how that defines the collegiate experience for students. There is the need to examine how economic factors affect student interest/ disinterest in the collegiate experience and how that affects their belief or value systems. As the world becomes increasingly global by virtue of technological advancement and the commonality in our destinies as punctuated by the slump in world market economy or the devastation suffered from natural disasters such as Hurricane Katrina, the 
Haitian earthquake or the political turmoil in Egypt or Libya we need to see commonalities in our bid to wrestle our humanity and become human again.

The current research findings are conclusive in terms of student independence and their proclivity to make their own choices with a minimal amount of hand holding. Evidence of a lack of a hand holding culture was confirmed by recruitment officers when asked about their modus operandi during recruitment. The college brochures on the other hand fed on the idea of promoting personalized instruction and hand holding in the academic experience. It must be mentioned however that the results from this study cannot be generalized to other freshmen in other universities; neither can blanket statements be made about juniors and seniors regarding their perceptions of their major choices. Future research can look at how juniors and seniors perceive their college majors and also interviews can be done with student respondents to complement their survey responses. A university wide survey for juniors and seniors which cuts across disciplines may reveal interesting data pertaining to this subject.

\section{Suggestions for Future Study}

As mentioned in the introduction in Chapter One, the use of freshmen and sophomores as the target respondents in this study limits the generalizability of the results. It is suggested that future research endeavors consider adding junior and senior populations and even nontraditional students to see if their perceptions about college major choices differ or are similar. It will also be interesting to run comparisons along the lines of gender, race and residency status to determine how these backgrounds influence student choices. Another interesting population to engage in this study will be general studies undecided students since that population of students is normally knee deep in the major selection process. Of particular interest in the general studies population will be students who have taken orientation classes which supposedly prepare them 
for career exploration through a series of activities such as job shadowing all in the hopes of getting them to decide on a major. Subsequent research can also gather rich data if a mixed method approach is utilized concurrently with focus group interviews with a segment of respondents who take the surveys. It will also be worthwhile if a longitudinal study can be crafted to follow up with students in a wide array of disciplines to see if they ended up in their desired occupations.

This current study has raked the surface of the oppressive tendencies authored by the market and how that affects our livelihoods. Most importantly, it has left an assurance that students are holding on to their humanity, wrestling it day in and day out as the society, nation and global village navigates an unpredictable age. Further research will unveil the character of this oppressive element and, most importantly reveal potent ways of subduing the phenomenon in our lives. As Freire (1973) mentions we need love, hope, trust as we attempt to wrestle our humanity from the oppressor. 


\section{References}

Apple, M.W. (1993). Official knowledge. New York: Routledge.

Arcidiacono, Peter and Sean Nicholson. (2005). Peer effects in medical school. Journal of Public Economics, 89, 327-350.

Barnett, R. (1994) The limits of competence. Buckingham: Open University Press.

Beggs, J. M., Bantham, J. H., Taylor, S. (2008). Distinguishing the factors influencing college students' choice of major. College Student Journal, 42, 381-394.

Berger, M.C. (1988a), "Cohort Size Effects on Earnings: Differences by College Major", Economics of Education Review 7, 375-383.

Berger, M.C. (1988b). Predicted future earnings and choice of college major. Industrial and Labor Relations Review 41, 418 - 429.

Bobbit, F. (1918).The curriculum. New York: Houghton Mifflin.

Bok, D. (2003). Universities in the marketplace: The commercialization of higher education. Princeton, NJ: Princeton University Press.

Bourdieu, P. (1990). The Field of cultural reproduction. New York: Columbia University Press.

Cabrera, A. F. La Nasa, S.M. (2002). Understanding the college-choice process. New Directions for Institutional Research, 107.

Carpenter, D. (2006). More teenagers turning to professional career coaches. Associated Press in The Pantograph, Bloomington, IL (May 1, 2006). 
Cooper, J. (2009). We don't speak their language: Radical creativity with branding. Journal of College Admission, 203, 14-17.

Coleman, J.S., Campbell, E.Q., Hobson, C., McPartland, J., Mood, A., Weinfield, F.D. and York, R., 1966. Equality of educational opportunity. Government Printing Office, Washington, DC.

Corcoran, M. E., Courant, P. N. (1985). Sex role socialization and labor market outcomes. American Economic Review, 75, 2, 275-78.

DeMarie, D., \& Aloise-Young, P.A. (2003). College students' interest in their major. College Student Journal. 37(3), 462-469.

Dewey, J. (1944).Democracy and education: An introduction to the philosophy of education. New York: The Free Press.

Dunne, E. (1999). The learning society: International perspectives on core skills in higher education. London: Kogan Page.

Douvan, E. (1976). The role of models in women's professional development. Psychology of Women Quarterly, 1, 5-20.

Eisner, E. W.(1979). The educational imagination: on the design and evaluation of school programs. New York: Macmillan.

Freire, P. (1973). Education for critical consciousness. New York: Seabury Press. Gallotti, K. M. (1999). Making a “major” real - life decision: College students choosing an academic major. Journal of educational psychology, 91, 2, 379387.

Giroux, H. (1988). Teachers as Intellectuals: Toward a critical pedagogy of learning: Massachusetts: Bergin and Garvey. 
Hartley, M., Morphew, C. (2008).What's being sold and to what end? A content analysis of college view books. The Journal of Higher Education, 79, 6.

Hall, J.W., Kelves, B.L. (1983). The social imperatives for curricula change in higher education. In Hall, J.W.,kevles, B. eds. In Opposition to Core Curriculum: Alternative models for undergraduate education. Greenwood: Heinemann Publishing.

Holsti, O.R. (1969). Content analysis for the social sciences and humanities. Reading, MA: Addison-Wesley.

Hossler, D., Schmit, J., \& Vesper, N. (1999). Going to college: How social, economic, and educational factors influence the decisions students make. Baltimore, MD: Johns Hopkins University Press.

Hoover, E. (2008). What admissions officials think: A Chronicle survey finds uneasiness over rising costs, recruitment, and public opinion. The Chronicle of Higher Education, B3 - B-4.

Hutchins, R.M. (2003). The Higher Learning in America. New Jersey, Yale University Press.

Illich, I. (1970). Deschooling society. New York: Harper \& Row

Kaplan, M. (1983). The Wrong Solution to the Problem. In Hall, J. W., kevles, B. eds. In Opposition to Core Curriculum: Alternative models for undergraduate education. Greenwood: Heinemann Publishing.

Klassen, L. (2000). Lots of fun, not much work, and no hassles: Marketing images of higher education. Journal of Marketing for Higher Education, 10(2), 11-26.

Kerr, C. (2001). The uses of the university. London: Harvard University Press. 
Kippendorff, K. (2004). Content analysis: An introduction to its methodology (2nd ed.). Thousand Oaks, CA: Sage.

Labaree, D. F. (1997). Public goods, private goods: The American struggle over educational goals. American Educational Research Journal, 34(1), 39-81.

Lamdin, L. (1983). Curricular coherence and the individual student. In Hall, J.W.,kevles, B. eds. In Opposition to Core Curriculum: Alternative models for undergraduate education. Greenwood: Heinemann Publishing.

Leppel, K. (2001). The Impact of major on college persistence among freshmen. Higher Education, 41, 3, 327-342.

Leppel, K. Williams, M.L. \& Waldauer (2001). The impact of parental occupation and socioeconomic status on choice of college major. Journal of Family and Economic Issues, 22,4.

Lyle, D. S. (2007). Estimating and interpreting peer and role model deficits from randomly assigned social groups at west point. The Review of Economics and Statistics, 89, 2, 289-299.

Kimweli, D.M.S., \& Richards, A.G. (1999). Choice of a major and students' appreciation of their major. College Student Journal, 33(1), 16-26.

Malgwi, C.A., Howe, M. A., \& Burnaby, P.A. (2005). Influences on students' choice of college major. Journal of Education for Business, 80(5), 275-282.

McLaren, P. (2007) Life in schools. New York: Pearson.

McDill, E.L., Coleman, J. (1965). Family and peer influences in college plans of high school students. Sociology of Education, 38, 2, 112-126.

Montmarquette, C. Cannings, K. \& Mahseredjian, S. (1997). How do young 
people choose college majors? Economics of Education Review, 21(6), 543556.

Muscatine, C. (1983) Towards a new curriculum. In Hall, J.W.,kevles, B. eds. In Opposition to Core Curriculum: Alternative models for undergraduate education. Greenwood: Heinemann Publishing.

Patton, M.Q. (2002). Qualitative research and evaluation methods. London: Sage Publications.

Pinar, W.F., Reynolds,W.M., Slattery, P., Taubman,P. M. (2004). Understanding Curriculum. New York: Peter Lang.

Postman, N. (1996). The end of education: Redefining the value of school. New York: Knopf.

Pulliam, J.D. (1991).History of education in america. New York: Macmillan Publishing Company.

Sacerdote, B. (2001). Peer effects with random assignment: results for dartmouth roommates. Quarterly Journal of Economics, 116, 681-704.

Shampeny, R. (2003). Colleges turn attention to branding in competition for new students. The Business Review. Retrieved on November 11, 2006 from http://www.bizjournals.com/albany/stories/2003/10/27/focus5.html

Shapiro, H.S. (1998). Critical issues in american education: Transformation in a postmodern world. London: Lawrence Erlbaum Publishers.

Thomas, S.L., Zhang, L. (2005). Post - baccalaureate wage growth within 4 years of graduation: The effects of college quality and major. Research in Higher Education, Vol. 46, No. 4. 
Tyler, R.W. (1949). Basic principles of curriculum and instruction. Chicago: The University of Chicago Press.

Wilshire, B. (1990). The moral collapse of the university: Professionalism, purity, and alienation. New York: State University of New York Press.

Zemsky, R., Wegner, G. R., William, F.M. (2005). Remaking the American university: Market- smart and mission centered. New Jersey: Rutgers University Press. 


\section{Appendix A -IRB Protocol}

\section{IRB PROTOCOL - Details}

Tracking \# H-21525

PI Obenauf, Patricia

Title Wrestling for Our Humanity: An Examination of College Degree Choice Processes by freshmen and sophomores at West Virginia University.

Version 2

Status Exempt

Status Date $3 / 5 / 2009$ 2:14:25 PM

Board Board Gold

Meeting Date

Approval Date $03 / 05 / 2009$

Expiration Date 


\section{Appendix B - CITI Training Certificate}

\section{CITI Collaborative Institutional Training Initiative}

Human Research Curriculum Completion Report Printed on 2/10/2011

Learner: Cyprien Lokko (username: 1cyclonenii)

Institution: West Virginia University

Contact Email: cyprien.lokko@gmail.com

Information

IRB Members:

Stage 2. Refresher Course Passed on 10/07/08 (Ref \# 2197020)

Required Modules

Refresher Course 200 Introduction

SBR 101 REFRESHER MODULE 1. History and Ethics

SBR 101 REFRESHER MODULE 2. Regulatory

Overview

SBR 101 REFRESHER MODULE 3. Fundamental

Issues.

SBR 101 REFRESHER MODULE 4. Vulnerable Subjects

SBR 101 REFRESHER MODULE 5. Additional Topics

How to Complete The CITI Refresher Course and

Receive the Completion Report

History and Ethical Principles.

Regulations and Process, Part 1

Regulations and Process, Part 2

Informed Consent.

Social \& Behavioral Research (SBR)

Genetics Research, Part 1

Genetics Research, Part 2

Records-Based Research, Part 1

Records-Based Research, Part 2

Records-Based Research, Part 3

Research with Protected Populations - Vulnerable

Subjects: A Definition.

Vulnerable Subjects - Prisoners, Part 1

Vulnerable Subjects - Prisoners, Part 2

Studies With Minors, Part 1

Studies With Minors, Part 2

Studies With Minors, Part 3

Studies with Pregnant Women and Fetuses, Part 1

Studies with Pregnant Women and Fetuses, Part 2

Group Harms: Research with Culturally or Medically Vulnerable Groups.

FDA-Regulated Research, Part 1

FDA-Regulated Research, Part 2

HIPAA and Human Subjects Research.

Conflicts of Interest in Research Involving Human

Subjects.

How to Complete the CITI Refresher Course and Receive

a Completion Report
Completed

$10 / 07 / 08$

$10 / 07 / 08 \quad 5 / 5(100 \%)$

$10 / 07 / 08 \quad 5 / 5(100 \%)$

$10 / 07 / 08 \quad 5 / 5(100 \%)$

$10 / 07 / 08 \quad 4 / 4(100 \%)$

$10 / 07 / 08 \quad 5 / 5(100 \%)$

$10 / 07 / 08$ no quiz

$10 / 07 / 08$ no quiz

$10 / 07 / 08 \quad 1 / 1(100 \%)$

$10 / 07 / 08 \quad 1 / 1(100 \%)$

$10 / 07 / 08 \quad 1 / 1(100 \%)$

$10 / 07 / 08 \quad 2 / 2(100 \%)$

$10 / 07 / 08 \quad 1 / 1(100 \%)$

$10 / 07 / 08 \quad 1 / 1(100 \%)$

$10 / 07 / 08 \quad 1 / 1(100 \%)$

$10 / 07 / 08 \quad 1 / 1(100 \%)$

$10 / 07 / 08 \quad 1 / 1(100 \%)$

$10 / 07 / 08 \quad 1 / 1(100 \%)$

$10 / 07 / 08 \quad 1 / 1(100 \%)$

$10 / 07 / 08 \quad 1 / 1(100 \%)$

$10 / 07 / 08 \quad 1 / 1(100 \%)$

$10 / 07 / 08 \quad 1 / 1(100 \%)$

$10 / 07 / 08 \quad 1 / 1(100 \%)$

$10 / 07 / 08 \quad 1 / 1(100 \%)$

$10 / 07 / 08 \quad 1 / 1(100 \%)$

$10 / 07 / 08 \quad 3 / 3(100 \%)$

$10 / 07 / 08 \quad 1 / 1(100 \%)$

$10 / 07 / 08 \quad 2 / 2(100 \%)$

$10 / 07 / 08 \quad 2 / 2(100 \%)$

$10 / 07 / 08 \quad 2 / 2(100 \%)$

\begin{tabular}{l|l}
$10 / 07 / 08$ no quiz \\
\hline
\end{tabular}

For this Completion Report to be valid, the learner listed above must be affiliated with a CITI participating institution. Falsified information and unauthorized use of the CITI course site is unethical, and may be considered scientific misconduct by your institution. 


\title{
Appendix C - Cover Letter sent to Students and Recruitment Officers
}

\author{
Department of Curriculum \& Instruction/Literacy Studies \\ WestVirginiaUniversity.
}

College of Human Resources and Education

Dear Participant,

This letter is a request for you to take part in a research project to assess how freshmen and sophomores go about choosing majors at WVU. This project is being conducted by Cyprien Lokko, MA in the Undergraduate Advising Services Center at WVU with supervision of Dr. Patricia Obenauf, a professor in the College of Human Resources and Education, for a Doctoral Degree in Curriculum and Instruction. Your participation in this project is greatly appreciated and will take approximately 20 minutes to answer a few interview questions.

Your involvement in this project will be kept as confidential as legally possible. All data will be reported in the aggregate. You must be 18 years of age or older to participate. I will not ask any information that should lead back to your identity as a participant. Your participation is completely voluntary. You may skip any question that you do not wish to answer and you may discontinue at any time. West Virginia's University's Institutional Review Board acknowledgement of this project is on file.

I hope that you will participate in this research project, as it could be beneficial in understanding the impact of student college major choices at WVU. Thank you very much for your time. Should you have any questions about this letter or the research project, please feel free to contact Cyprien Lokko at (304) 293-5805 or by e-mail at cyprien.lokko@mail.wvu.edu.

Thank you for your time and help with this project.

Sincerely,

Cyprien Lokko, MA

304-906-7358

cyprien.lokko@mail.wvu.edu

Patricia Obenauf, EdD

304- 293-4376

pobenauf@wvu.edu 


\section{Appendix D-Survey questions for Freshmen and Sophomores}

1. Gender

a) Male

b) Female

2. Ethnicity

a) African American

b) Pacific highlander

c) Caucasian

d) Hispanic

e) Asian

f) Other

3. What is your academic classification?

a) First Semester Freshman

b) Second semester freshman

c) First semester sophomore

d) Second semester sophomore

4. What is your admission status at WVU?

a) In state student

b) Out of state student

c) International student

d) Non - traditional student

5. What major are you pursuing? (Check all that apply if pursuing multiple majors).

Pre-Biology(BA)

Pre-Biology(BS)

Pre-Biochemistry

Pre-Business and Economics

Pre-Business and Foreign Languages(BFL)

Pre-Chemistry(BA)

Pre-Chemistry(BS)

Pre-Communication Studies

Pre-Criminology

Pre-English

Pre-Foreign Languages

Pre-Forensics

General Studies

Geology (BS) 
General Studies/Engineering

Pre-Journalism

Pre-Liberal Arts and Sciences Pre-Mathematics(BA)

Pre-Mathematics(BS)

Pre-Medical Technology

Pre-Nursing(BA)

Pre-Pharmacy

Pre-Political Science Pre-Psychology (BA)

Pre-Psychology (BS)

Pre-Sociology and Anthropology

6. What is the highest level of formal education your parents/guardians have?
a) High school
b) College
c) Vocational
d) Professional degree ( Lawyer, MD,DDS, )
e) Doctoral degree $(\mathrm{PhD}, \mathrm{EdD}$,
f) Other

7. How will your parents or guardians react if you changed your major?
a) Support you fully
b) Check on the marketability of new major
c) Leave you to decide what is best for you
d) Oppose if your choice of major does not appeal to them

8. To what extent have you used any of the following financial resources for funding your college education? Please rate the level of importance attached to each of these resources using the scale below where: $5=$ A great extent, $4=$ Much, $3=$ Somewhat, $2=$ Little, and $1=$ Never.

$\begin{array}{llllll}\text { Student loans } & 1 & 2 & 3 & 4 & 5 \\ \text { Grants } & 1 & 2 & 3 & 4 & 5 \\ \text { Scholarships } & 1 & 2 & 3 & 4 & 5 \\ \text { Self-Pay } & 1 & 2 & 3 & 4 & 5 \\ \text { Parents } & 1 & 2 & 3 & 4 & 5\end{array}$


9. To what extent have the following individuals or factors influenced your decision to come to WVU? Please respond to this question using the scale below where: $5=\mathrm{A}$ great extent, $4=$ Much, $3=$ somewhat, $2=$ Little, and $1=$ Never.

$\begin{array}{lllllr}\text { Self } & 1 & 2 & 3 & 4 & 5 \\ \text { Parents } & 1 & 2 & 3 & 4 & 5 \\ \text { High School Guidance Counselor } & 1 & 2 & 3 & 4 & 5 \\ \begin{array}{lllll}\text { Peers } \\ \text { Cost of Tuition }\end{array} & 1 & 2 & 3 & 4 & 5 \\ \text { Appeal of the city of Morgantown } & 1 & 2 & 3 & 4 & 5 \\ \text { College Recruiters } & 1 & 2 & 3 & 4 & 5 \\ \text { Other } & 1 & 2 & 3 & 4 & 5\end{array}$

If you attached a high level of importance to the item "other", please explain further in the box below:

10. To what extent did the following factors influence your choice of a college major?

Please respond to this question using the Likert scale below where: $5=$ A great extent, 4= Much, 3= Somewhat, 2= Little, and $1=$ Never.

Passion for the discipline

$\begin{array}{lllll}1 & 2 & 3 & 4 & 5\end{array}$

Peer Influence

$\begin{array}{lllll}1 & 2 & 3 & 4 & 5\end{array}$

Financial reward in the future

$\begin{array}{lllll}1 & 2 & 3 & 4 & 5\end{array}$

Academic advisor

$\begin{array}{lllll}1 & 2 & 3 & 4 & 5\end{array}$

Meeting family obligations

$\begin{array}{lllll}1 & 2 & 3 & 4 & 5\end{array}$

GPA requirements for major

$\begin{array}{lllll}1 & 2 & 3 & 4 & 5\end{array}$


College major entry requirements

Please explain in the box below if none of the above factors influenced your choice of a major.

11. What would you say has influenced your aspirations of getting into your major?

Please respond to this question using the scale below where: $5=$ A great extent, $4=$ Much, 3= Somewhat, $2=$ Little and $1=$ Not at all.

College experience of family and or friends

$\begin{array}{lllll}1 & 2 & 3 & 4 & 5\end{array}$

Popularity of major in the media

$\begin{array}{lllll}1 & 2 & 3 & 4 & 5\end{array}$

Prospects of advancement in the job market

$\begin{array}{lllll}1 & 2 & 3 & 4 & 5\end{array}$

Success of family or friends who hold a similar

$\begin{array}{lllll}1 & 2 & 3 & 4 & 5\end{array}$

degree as the one you are pursuing.

Job security

$\begin{array}{lllll}1 & 2 & 3 & 4 & 5\end{array}$

Passion for the discipline

$\begin{array}{lllll}1 & 2 & 3 & 4 & 5\end{array}$

12. What are some of the challenges you anticipate as you wait on getting into your major? Please respond to this question using the Likert scale below where: $5=\mathrm{A}$ great extent, 4= Much, 3= Somewhat, $2=$ Little, and $1=$ Not at all.

\begin{tabular}{|c|c|c|c|c|}
\hline Availability of funds & 1 & 2 & 3 & 4 \\
\hline Meeting departmental requirements & 1 & 2 & 3 & 4 \\
\hline Staying on track & 1 & 2 & 3 & 4 \\
\hline Other & 1 & 2 & 3 & 4 \\
\hline
\end{tabular}

Please explain in the box below if the item "other" received a high score for anticipated challenges. 
13. To what extent did the following factors influence your choice of a college major? Please respond to this question using the Likert scale below where: $5=$ A great extent, 4= Much, 3= Somewhat, 2= Little, and $1=$ Never.

$\begin{array}{llllll}\begin{array}{l}\text { Arriving at major choice through personal } \\ \text { research }\end{array} & 1 & 2 & 3 & 4 & 5 \\ \begin{array}{l}\text { Influence from peers } \\ \text { Suggestions from parents or siblings }\end{array} & 1 & 2 & 3 & 4 & 5 \\ \begin{array}{l}\text { Assurance of future success in chosen major } \\ \text { from someone working in a similar field }\end{array} & 1 & 2 & 3 & 4 & 5 \\ \begin{array}{l}\text { Research into the short term and long term } \\ \text { benefits of chosen major }\end{array} & 1 & 2 & 3 & 4 & 5 \\ \begin{array}{l}\text { Mentorship from academic advisor } \\ \text { Course requirements for intended major }\end{array} & 1 & 2 & 3 & 4 & 5 \\ \text { Passion for the major } & 1 & 2 & 3 & 4 & 5 \\ \text { Nature of work environment after graduation. } & 1 & 2 & 3 & 4 & 5\end{array}$

14. If your friends and family were not involved in your choice of your college major, would you still have selected your current major?
a)Yes
b) No

15. Has your upbringing (schooling, attachment to family and or friends) influenced the direction of your college career in any way?
a) Yes
b) No

16. If departmental requirements and future financial rewards associated with all majors were the same, will you still stay in your current major?
a)Yes
b) No 
17. Did you or your parents and guardians consider tuition costs of majors before committing to your current major?
a) Yes
b) No

18. If you had access to an educational scholarship with no pay back obligations, will you reconsider a major change?
a) Yes
b) No

19. Does the thought of having to pay back student loans influence your current major choice?
a) Yes
b) No

20. If all the majors offered in WVU gave you the opportunity to design your own course of study, would you be interested.
a) Yes
b) No 


\section{Appendix E - Interview Questions for WVU Recruitment officers.}

\section{Name}

\section{Recruiting Role}

1. What is the mission of the West Virginia University Recruitment center?

2. What are your main selling points when promoting WVU to prospective students?

3. What majors or colleges draw prospective students the most to WVU?

4. Whom do you interact with most during recruitment drives?

5. What are some of the concerns your clients have expressed in the past concerning the pursuance of a prospective college degree?

6. What are some of the factors or reasons you have come across in your recruitment drive that draw students to Morgantown?

7. What are some of the challenges you encounter in the recruitment effort?

8. How has the down turn in the economy affected your recruitment strategy?

9. What in your opinion makes you a successful recruiter?

10. If you knew what you know about majors in your college days would you have still pursued the major you graduated with? 


\section{Appendix F-Interview Transcripts for Recruitment Officers Francois}

1. What is the mission of the West Virginia University Recruitment center?

Now are you asking about the mission as it relates with my job as a communication specialist or the general mission of the unit. Um, our goal, we always want to meet the needs of our students by helping them get what information or assistance the need to choose what degree program they are interested in.

2. What are your main selling points when promoting WVU to prospective students?

I would say generally Cost and Opportunity

3. What majors or colleges draw prospective students the most to WVU?

Academic programs? Um again it's hard to say, we offer a hundred and eighty degree programs and on any given day you could talk to a student who is interested in any of those hundred and eighty degree programs. Um, I think Engineering, the Forensics program, our large liberal Arts college and our Honors College, you know, all of those are pretty common programs that we talk about.

4. Whom do you interact with most during recruitment drives?

I actually work less with prospective students than my co - workers because I am not travelling to the territories like they are. I often times will be emailing the parents and students but what I do on a daily basis I actually interact with current students more frequently than prospective students. So some students may be interested in the forensics programs but may not have the grades to be admitted. 
5. What are some of the concerns your clients have expressed in the past concerning the pursuance of a prospective college degree?

Again that entirely depends on the student, I think um with the current economy, to non residents scholarships and cost are an increasing concern, um whether or not the university offers a major, they are a lot of cases where a student is interested in a major but the concern then becomes whether the student will be admitted to the major.

6. What are some of the factors or reasons that draw students to Morgantown? Right, we like to talk about Morgantown being a small city which has the amenities found in larger cities, Like public transportation, um you know shopping, movies, arts you those sort of things but without the typical negative attributes of a larger city. Our crime rates are really low, transportation in town is easy, and we are somewhat sub urban - so those are the things that I think appeal to students. I also think that the recreational facilities we have and our central location makes a good selling point to students.

7. What are some of the challenges you encounter in the recruitment effort?

You know I think the biggest challenge is that we can only offer students information and because of the way the university is set up, scholarships are pre - determined so if we are working with a student who is maybe a great candidate for WVU but is not really meeting the scholarship requirements then we are not really going offer that student a place.

8. How has the down turn in the economy affected your recruitment efforts? Well, a little hard to determine at this point, um we started doing some surveys of last year's recruitment class for those students who did enroll to see why they are enrolling, um I think, I don't feel comfortable answering that question specifically because the 
research is not in yet, because with the economy starting a down turn last year and the year before that, we haven't been able to measure, um response um, but I think some of the concerns with the economy and with higher education as a whole not just WVU is the view that is probably going to affect our recruitment rates because if you are a non resident student you may be able to go to an out of state college but let's say your parents have lost a job and now you will have to go home. Such student may not be enrolling in the future.

9. What in your opinion makes you a successful recruiter?

Someone who is able to interact with students and their families to determine what academic need they have and how WVU can meet that need. WVU is not for everyone and so as you are recruiting you have to be able to figure out how to meet the needs of the students.

10. If you knew what you know now about majors in your college days, would you have still pursued the major with which you graduated? I was an English and Political science undergraduate major and I am not sure that I would have changed majors, may be at the Masters level. I got a Masters degree in creative marketing. I definitely did not know how many degree programs out there until I started this career. 


\section{Interview Transcripts for Recruitment officers. \\ Brittany}

1. What is the mission of the West Virginia University Recruitment center?

The mission is to... Again you said to make it personal for me? Okay the mission to attract prospective students- we go out to the high schools, we set college fares, we are there to answer any questions that they have throughout the process and just to make sure that they have somebody they know that they can always call or email and they will be there?

2. What are your main selling points when promoting WVU to prospective students?

Um always the amount of majors that we have that is a big selling point because they have a lot of flexibility, um, our tuition, our fees, because they are very reasonably priced especially for out of - state students. Sometimes it's less expensive to come here than it is to go to some schools in state. Um there are over three hundred student organizations for them to get involved in, our academics, we always highlight the programs that are doing very well that have students succeeding and are ranked high nationally. So those are the big things, athletics also, there are some students not all of them, athletics can be a big selling point also.

3. What majors or colleges draw prospective students the most to WVU?

Forensics is a very large one, since we do have one of the best forensics programs, a lot of students will come here for that. Pharmacy, Business, Engineering, Journalism. Really 
we get a lot across the board but these ones are probably the biggest ones I have encountered so far.

4. Whom do you interact with most during recruitment drives?

I interact a lot with the students themselves and then um, a lot of times I would interact with their families and parents and grandparents, and um there is also a large interaction between us and the high school counselors, um just working with them to schedule high school visits and they really know the students well so just working with them.

5. What are some of the concerns your clients have expressed in the past concerning the pursuance of a prospective college degree?

Um really, see, with my territory, distance, distance from home. It seems to be- and I have to say as far as concern wise, I am fairly new to this position so I haven't been out in the territory a lot and so as of right now I actually haven't heard a lot of concerns. So out of those few that I have had distance seems to be the one that comes up a lot.

6. What are some of the factors or reasons that draw students to Morgantown?

A big one, a lot of people say that after one state visit, they feel this is a good fit for them so we really try to get students to campus, once they are here, they like the atmosphere , they like the surroundings, they like the school. I mean and obviously the academics, when you can get a large school, you know, all the benefits of a large school, are here, the academics, athletics and the facilities but then they also get a small school feel in their majors and in their classes a lot of the times so that's a really really big selling point that attracts a lot of students. 
7. What are some of the challenges you encounter in the recruitment effort?

Um, probably stereotypes about the region, about the school and I would say probably, $99 \%$ of them aren't accurate so you have to kind of, you know, work with that a lot because there is a lot of wrong information. So it is making sure that students have accurate information to make a decision on. Often times once you kind of put the facts in front of them you can kind of see a change in their reaction, like I said most of the time a lot of the information they have is wrong so when we are able to present the real information, it really helps.

8. How has the down turn in the economy affected your recruitment efforts?

As of right now, we are not really sure, we are still kind of analyzing the data of this year's incoming class. Um, the incoming class is smaller than last year, but it was kind of a purposeful thing at our end because we did admit such a large class last year, um so as far as the economy we haven't been really able to analyze that data to see if it played a part.

9. What in your opinion makes you a successful recruiter?

I think someone that can relate to the students, that can um, speak and talk to them and not just put facts in front of them, that also interacts with them, makes, help the prospective students visualize all the facts about the university, you know find out what they like, find out what they enjoy and then relate it to opportunities at the university.

10. If you knew what you know now about majors in your college days, would you have still pursued the major with which you graduated? 
Yes, I think I would have, I went to WVU, and I graduated this past summer and I switched my major couple of times but I think that even looking back I would probably start in the major that I finish in. 


\section{Interview Transcripts for Recruitment Officers}

\section{Gabrielle}

\section{What is the mission of the West Virginia University Recruitment center?}

I mean, I guess as far as our personal mission goes we are out there to recruit for the university to um find students that would fit while enrolled here in our institution. Students who are looking for the academic skills that we offer as far as academics go but also for the type of environment that we have because you know we are a large university in a small town, so like in Ohio for instance, they have several major universities but it's different because they offer different programs which will be in different environments, larger classrooms maybe in a bigger city so fit is very important and it encompasses a lot of things and academics is certainly one of them.

\section{What are your main selling points when promoting WVU to prospective students?}

I can for my territory; it really has to do with a large university in a small town. There is also something that we have called the reciprocity agreement, um I can get you a paper with what's on it. With the reciprocity agreement certain majors that are underrepresented in Ohio, a lot of them fall within the Davis College agricultural majors. Students can come to WVU and get In State tuition um like I said they are underrepresented majors. That is a selling point, some of the more rural counties have students interested in the majors, um other selling points, you know other things that are just popular everywhere, athletics has got us notoriety, um you know the state itself, there is plenty you can do outside, white water rafting, rock climbing, a lot of students reaching out to city find that it is a popular place. 


\section{What majors or colleges draw prospective students the most to WVU?}

Um, well because of the reciprocity agreement, our say the ones listed on the reciprocity document draw a lot of students from Ohio. We also have programs that are not necessarily scarce but are popular like Engineering Business, certainly a lot of programs from the Eberly Arts and Sciences College, um pretty diverse what students are studying. But we will spend time with our underrepresented majors, um like music or um big majors that don't necessarily have the numbers the other majors do- if we find a student who is interested in one of those majors then we will up our game a little bit making sure they have all the information that they need. We try to stay in contact, go the extra mile to make sure they know about us.

4. Whom do you interact with most during recruitment drives?

At this point mostly students, um certainly our other audiences are parents and guidance counselors, um but the majority of our efforts are with students.

5. What are some of the concerns your clients have expressed in the past concerning the pursuance of a prospective college degree?

Um, you know especially right now, the cost, it is a big factor, um again for Ohio, a lot of the instate schools are the same as our out of state prices if not less. If that's not the case, in some of our territories like New England, New Jersey, Pennsylvania their instate tuition is sometimes less or more than what out state tuition is but um for Ohio, cost is certainly a concern. Um distance is a concern as well as awareness I think, um regardless of where you are from you are Ohio State fans and these students don't know about WVU. 
6. What are some of the factors or reasons that draw students to Morgantown?

Um I think you know like I said the school what it offers as far as academics and attractions of campus, um also just the city of Morgantown and West Virginia, I think the friendliness, and the people that they meet here um - I think that comes from it being a small community, they feel like they know their professors and they feel like they can really talk with and ask questions throughout the recruitment process. They feel welcome I guess.

7. What are some of the challenges you encounter in the recruitment effort?

Um again awareness, um overcoming the OSU mentality, even though their fans, they are not going to go there, that is not the best fit for them; they don't want to look beyond that. They blind themselves to whatever is out there. Um that is probably the biggest challenge.

8. How has the down turn in the economy affected your recruitment efforts?

Again, Ohio schools are cheaper, unless the students are under the reciprocity agreement then I would asking them to pay more to come, and it could be worth it, we certainly have the facilities, um programs and everything that they need.

9. What in your opinion makes you a successful recruiter?

I think you have to know about the school itself and what the school has to offer but I think you also have to know about the student so you can get them the information they are looking for. I can know everything about our Engineering program, that is great but if the student is not interested in that then it is fruitless. 
10. If you knew what you know now about majors in your college days, would you have still pursued the major with which you graduated?

That's an interesting question, I changed my major, I started as a Business and Foreign language major and then I moved to French and political science and then had a Masters in Marketing. Um I am going to say no because I found the work extremely interesting at the time and even though I moved out of Business as an undergrad; I followed up with it as a grad student to make myself more marketable. Um to be completely honest when I was choosing schools, I play sports and so academics wasn't necessarily my top priority, certainly I was a good student, I probably would have done things the same way. 


\section{Interview Questions for Recruitment officers. Sandra}

1. What is the mission of the West Virginia University Recruitment center?

We work to recruit new undergraduate students, including first-time freshmen and transfer students. There are separate recruitment offices for graduate/professional students and international students.

2. What are your main selling points when promoting WVU to prospective students? I manage most of the state of Pennsylvania. My prospective students are out-of-state students, so a top selling point at WVU is always our very competitive tuition/room/board cost. In addition to this, the academic programs, including their reputation as well as the number of programs, is always a positive selling point. Our facilities also are a top selling point, as we have wonderful facilities to support our academics. Top faculty, a very friendly campus that feels comfortable to students, and our many activities, clubs and organizations are also top sellers.

3. What majors or colleges draw prospective students the most to WVU?

STEM programs (science, technology, engineering, and math) are very strong programs of interest for WVU. The most popular programs students inquire about are: Forensics, engineering, nursing, pharmacy, physical therapy, business, political science.

4. Whom do you interact with most during recruitment drives?

I believe this question is referring to those out of the office that I work most closely with, and that would be prospective students and their families, guidance counselors and career 
counselors in high schools, college fair organizers, current Mountaineer parents (MPC) and alumni.

5. What are some of the concerns your clients have expressed in the past concerning the pursuance of a prospective college degree?

Cost is certainly on everyone's mind these days, so many students and parents inquire about costs, financial aid, and scholarships. Job opportunities post-graduation, internships, and advising are other topics of concern.

6. What are some of the factors or reasons that draw students to Morgantown? Students often tell me after visiting Morgantown and the campus that it is not at all what they thought it would be. They very much like the idea of a smaller, more rural area that still has many modern retail places and commodities. They like the idea of the campus and university being a focus of the community and that the support the university receives from the community of Morgantown is evident.

7. What are some of the challenges you encounter in the recruitment effort?

The stigma of West Virginia is sometimes a challenge, as well as location. Many students do not realize that we are very close to the PA border and are not aware of our location. They think we are further away from their home than we are or further south. Also, the "party school" image has often been a challenge.

\section{How has the down turn in the economy affected your recruitment efforts?}

I think all students and families are being more frugal these days and are comparing costs. Although I continue to see an increase in interest in my market, I do have many 
families comparing costs and waiting for financial aid awards or scholarships before making decisions to attend.

\section{What in your opinion makes you a successful recruiter?}

First, I love what I do and love working for WVU. I have been working in college admissions for 8 years and truly enjoy working for a large flagship institution such as WVU. I love the support we receive on campus and in the community and that our alums have had a great experience and have been successful with their degree. I also think I am successful because I am very eager to assist families who have not been through the college admissions process before. Many students are first generation college students, and I was as well when I attended college. The process can be very intimidating and time consuming. I like helping them with the administrative part of the process, but also enjoy helping them to learn about what they are looking for in a school and how WVU may be a good fit.

10. If you knew what you know now about majors in your college days, would you have still pursued the major with which you graduated?

No. I have a degree in Hotel, Restaurant, and Institutional Management. Although I very much enjoyed my career in the field, I had no idea what the quality of life schedule would be like and the demand it would have on my personal life. However, I do very much like what I do now, and probably would not be in college admissions had I not had some sales experience in another field. The skill set I learned while working in my previous career was very transferrable. I like the fact that when counseling students about career options and majors, guidance and career counselors as well as recruitment representatives are teaching students that there are many things to consider depending on what they want to do and how they want to do it. 


\section{Interview Transcripts for Recruitment Officers}

\section{Nancy}

\section{What is the mission of the West Virginia Recruitment Center?}

Um well um we want to bring um the most information to prospective students as possible about the university and in particular for our office, just to assist them as much as we can through the admissions process and help them to reach their goals in higher education.

\section{What are your main selling points when promoting WVU to prospective}

\section{students?}

Um, well I will say one of our main selling points is to discuss the affordability of the institution; um we also talk about um the various degree programs we offer and the quality of our academic programs and um our proximity to other- I mainly recruit in northern Virginia so the proximity to um you know that area is only about between three hours to three and a half hours for students and that's a good selling point. And then another good selling point is the community of Morgantown, how it is um a small community but is very supportive of the students and then probably the last I can talk about is the caring, how our faculty and staff really care about the students.

\section{What majors or colleges draw prospective students the most to WVU?}

$\mathrm{Um}$, there is really not just one, there is probably about three that I get asked of the most and yeah I would our top three are the college of Business and Economics, the majors within that school, um our college of engineering and mineral resources and then our Forensics Identification Program. 


\section{Whom do you interact with most during recruitment drives?}

Yeah, um the most will be, definitely the students, the most um you know, I interact with guidance counselor and you know school officials, um definitely the most is students and then I would say guidance counselors next.

\section{What are some of the concerns your clients have expressed in the past} concerning the pursuance of a prospective college degree?

Concerns, um let's see, a lot of students I think come aware - even though we are pretty affordable option for students um, a lot of times they have concerns about out of state tuition, they being able to afford it - what type of financial aid are out there, um and then um they want to know I guess essentially the value of their degree and what career opportunities are they going to be able to um aspire to by going through the program.

\section{What are some of the factors or reasons that draw students to Morgantown?}

Yeah, um well we have a lot of alumni in this area and most are parents who have experienced Morgantown and they want their kids to have that experience too. Yeah, and then definitely not for all students but a lot of students you know they hear about our school spirit and our athletic programs and they are interested in being a part of a school that has a modest spirit like we do and um and I believe there are also a lot of students who are attracted to our location again not only because of proximity but also our outdoor recreation in the area. And then I think once they do some research and especially come to visit campus and take a tour or you they are attracted to just our campus, the look of our campus, um and um all 
the different amenities that we offer like the PRT and the recreation center um that's a big attraction too and um right.

\section{What are some of the challenges you encounter in the recruitment effort?}

Some of the challenges will be particularly for me will be - in Virginia there are lot of good state schools here, one of my challenges is trying to get the students to consider you know other options outside of Virginia so that is probably my concern. Probably overall for our office as a whole, I would say especially the economy - right now, you know one of our concerns is you know students are choosing to go to community colleges and then transfer so that's a challenge for us trying to get them to um start at the University.

\section{How has the down turn in the economy affected your recruitment efforts?}

Yeah I think you know it definitely has this year um, our numbers are down a little bit as far as our applications and um but that was sort of done on purpose, the economy had something to do with it but we did that a little intentionally. Well um we had such a large freshman class last year so we lowered our expectations, not really lowered our expectations, I guess kind of changed our mindset for the size of the freshman class we wanted but the economy is definitely um definitely played a factor you know a lot of students who couldn't get financial aid offers or scholarship options are looking elsewhere.

\section{What in your opinion makes you a successful recruiter?}

Um well um, definitely you have to be um approachable and be able to talk with just about any one- you know you are going to run into so many different people um, students and parents and you know almost everybody has a different situation or 
different concerns so you have to be really approachable and you have to really know the school, do your research and um know what you are talking about. You have to be credible - people can tell you know if you are kind of BSing them, yeah and you have the - our office, you know we travel a lot and we have a lot of events and you have to be flexible in order to um and I think it's important to be able to answer as many questions as you can for them and if you don't know the answer or something definitely find it for them and get in touch with them. Make sure they know that you are willing to help them as much as you can; you know really good customer service skills basically.

\section{If you knew what you know now about majors in your college days, would you have still pursued the major with which you graduated?}

Um that is an excellent question, I think about that a lot actually, you know um I doyou know what I don't know if I would have or not. Honestly I know so much more now about the different programs, so much more about all the different career opportunities out there for the different majors, um so honestly me personally I probably would have changed 
Appendix G- Quantitative Data for Freshmen and Sophomore Surveys

Gender

\begin{tabular}{|ll|r|r|r|r|}
\hline & & Frequency & Percent & Valid Percent & $\begin{array}{c}\text { Cumulative } \\
\text { Percent }\end{array}$ \\
\hline Valid & Male & 238 & 51.2 & 51.2 & 51.2 \\
& Female & 227 & 48.8 & 48.8 & 100.0 \\
& Total & 465 & 100.0 & 100.0 & \\
\hline
\end{tabular}

Ethnicity

\begin{tabular}{|ll|r|r|r|r|}
\hline & & Frequency & Percent & Valid Percent & $\begin{array}{c}\text { Cumulative } \\
\text { Percent }\end{array}$ \\
\hline Valid & Caucasian & 410 & 88.2 & 89.3 & 89.3 \\
& African American & 23 & 4.9 & 5.0 & 94.3 \\
& Hispanic & 10 & 2.2 & 2.2 & 96.5 \\
& Asian & 8 & 1.7 & 1.7 & 98.3 \\
& Pacific Islander & 1 & .2 & .2 & 98.5 \\
& Other & 7 & 1.5 & 1.5 & 100.0 \\
& Total & 459 & 98.7 & 100.0 & \\
Missing & 7 & 6 & 1.3 & & \\
Total & & 465 & 100.0 & & \\
\hline
\end{tabular}

Academic Classification

\begin{tabular}{|c|c|c|c|c|c|}
\hline & & Frequency & Percent & Valid Percent & $\begin{array}{c}\text { Cumulative } \\
\text { Percent }\end{array}$ \\
\hline \multirow[t]{5}{*}{ Valid } & First Semester Freshman & 16 & 3.4 & 3.5 & 3.5 \\
\hline & $\begin{array}{l}\text { Second Semester } \\
\text { Freshman }\end{array}$ & 293 & 63.0 & 63.3 & 66.7 \\
\hline & $\begin{array}{l}\text { First Semester } \\
\text { Sophomore }\end{array}$ & 20 & 4.3 & 4.3 & 71.1 \\
\hline & $\begin{array}{l}\text { Second Semester } \\
\text { Sophomore }\end{array}$ & 134 & 28.8 & 28.9 & 100.0 \\
\hline & Total & 463 & 99.6 & 100.0 & \\
\hline Missing & 5 & 2 & .4 & & \\
\hline Total & & 465 & 100.0 & & \\
\hline
\end{tabular}


Admission Status

\begin{tabular}{|ll|r|r|r|r|}
\hline & & Frequency & Percent & Valid Percent & $\begin{array}{c}\text { Cumulative } \\
\text { Percent }\end{array}$ \\
\hline Valid & In State Student & 211 & 45.4 & 45.6 & 45.6 \\
& Out of State Student & 244 & 52.5 & 52.7 & 98.3 \\
& International Student & 5 & 1.1 & 1.1 & 99.4 \\
& Non - traditional student & 3 & .6 & .6 & 100.0 \\
& Total & 463 & 99.6 & 100.0 & \\
Missing & System & 2 & .4 & & \\
Total & & 465 & 100.0 & & \\
\hline
\end{tabular}

Student Major

\begin{tabular}{|c|c|c|c|c|c|}
\hline & & Frequency & Percent & Valid Percent & $\begin{array}{l}\text { Cumulative } \\
\text { Percent }\end{array}$ \\
\hline \multirow[t]{23}{*}{ Valid } & Ple - Biology & 30 & 6.5 & 6.5 & 6.5 \\
\hline & Pre - Biochemistry & 6 & 1.3 & 1.3 & 7.7 \\
\hline & $\begin{array}{l}\text { Pre- Business and } \\
\text { Economics }\end{array}$ & 85 & 18.3 & 18.3 & 26.0 \\
\hline & $\begin{array}{l}\text { Pre - Business and } \\
\text { Foreign Language }\end{array}$ & 1 & .2 & .2 & 26.2 \\
\hline & Pre - Chemistry & 4 & .9 & .9 & 27.1 \\
\hline & $\begin{array}{l}\text { Pre-Communication } \\
\text { Studies }\end{array}$ & 9 & 1.9 & 1.9 & 29.0 \\
\hline & Pre- Criminology & 36 & 7.7 & 7.7 & 36.8 \\
\hline & Pre - English & 6 & 1.3 & 1.3 & 38.1 \\
\hline & Pre- Foreign Languages & 4 & .9 & .9 & 38.9 \\
\hline & Pre - Forensics & 7 & 1.5 & 1.5 & 40.4 \\
\hline & General Studies & 42 & 9.0 & 9.0 & 49.5 \\
\hline & Pre - Geology & 4 & .9 & .9 & 50.3 \\
\hline & Pre- Engineering & 29 & 6.2 & 6.2 & 56.6 \\
\hline & Pre - Journalism & 34 & 7.3 & 7.3 & 63.9 \\
\hline & $\begin{array}{l}\text { Pre- Liberal Arts and } \\
\text { Sciences }\end{array}$ & 11 & 2.4 & 2.4 & 66.2 \\
\hline & Pre - Medical Technology & 4 & .9 & .9 & 67.1 \\
\hline & Pre- Nursing & 28 & 6.0 & 6.0 & 73.1 \\
\hline & Pre - Pharmacy & 16 & 3.4 & 3.4 & 76.6 \\
\hline & Pre - Political Science & 9 & 1.9 & 1.9 & 78.5 \\
\hline & Pre- Psychology & 19 & 4.1 & 4.1 & 82.6 \\
\hline & $\begin{array}{l}\text { Pre- Sociology and } \\
\text { Anthropology }\end{array}$ & 6 & 1.3 & 1.3 & 83.9 \\
\hline & Pre - CDFS & 2 & -4 & .4 & 84.3 \\
\hline & $\begin{array}{l}\text { Pre - Human Nuitrition } \\
\text { and Foods }\end{array}$ & 6 & 1.3 & 1.3 & 85.6 \\
\hline
\end{tabular}


Student Major

\begin{tabular}{|c|c|c|c|c|c|}
\hline & & Frequency & Percent & Valid Percent & $\begin{array}{l}\text { Cumulative } \\
\text { Percent }\end{array}$ \\
\hline \multirow[t]{12}{*}{ Valid } & $\begin{array}{l}\text { Pre - Occupational } \\
\text { Therapy }\end{array}$ & 5 & 1.1 & 1.1 & 86.7 \\
\hline & $\begin{array}{l}\text { General Studies } \\
\text { Education }\end{array}$ & 20 & 4.3 & 4.3 & 91.0 \\
\hline & $\begin{array}{l}\text { General Studies - } \\
\text { Exercise Physiology }\end{array}$ & 6 & 1.3 & 1.3 & 92.3 \\
\hline & Pre - Social Work & 4 & .9 & .9 & 93.1 \\
\hline & Pre - Speech Pathology & 5 & 1.1 & 1.1 & 94.2 \\
\hline & Pre - Physics & 1 & .2 & .2 & 94.4 \\
\hline & Pre - Philosophy & 2 & .4 & .4 & 94.8 \\
\hline & Double Major & 18 & 3.9 & 3.9 & 98.7 \\
\hline & $\begin{array}{l}\text { Fashion Design and } \\
\text { Merchandizing }\end{array}$ & 1 & .2 & .2 & 98.9 \\
\hline & $\begin{array}{l}\text { General Studies - } \\
\text { Atheletic Training }\end{array}$ & 3 & .6 & 6 & 99.6 \\
\hline & Pre - Sports Management & 2 & .4 & .4 & 100.0 \\
\hline & Total & 465 & 100.0 & 100.0 & \\
\hline
\end{tabular}

Parent's Level of Education

\begin{tabular}{|ll|r|r|r|r|}
\hline & Frequency & Percent & Valid Percent & $\begin{array}{c}\text { Cumulative } \\
\text { Percent }\end{array}$ \\
\hline Valid & High School & 117 & 25.2 & 25.3 & 25.3 \\
& College & 252 & 54.2 & 54.4 & 79.7 \\
& Vocational & 11 & 2.4 & 2.4 & 82.1 \\
& Professional Degree & 54 & 11.6 & 11.7 & 93.7 \\
& Doctoral Degree & 19 & 4.1 & 4.1 & 97.8 \\
& Other & 10 & 2.2 & 2.2 & 100.0 \\
& Total & 463 & 99.6 & 100.0 & \\
Missing & 0 & 1 & .2 & & \\
& System & 1 & .2 & & \\
& Total & 2 & .4 & & \\
Total & & 465 & 100.0 & & \\
\hline
\end{tabular}


Parental Reaction to Major Change

\begin{tabular}{|ll|r|r|r|r|}
\hline & Frequency & Percent & Valid Percent & \multicolumn{1}{c|}{$\begin{array}{c}\text { Cumulative } \\
\text { Percent }\end{array}$} \\
\hline Valid & Support you fully & 277 & 59.6 & 59.7 & 59.7 \\
& $\begin{array}{l}\text { Check on Marketability of } \\
\text { new major }\end{array}$ & 70 & 15.1 & 15.1 & 74.8 \\
& $\begin{array}{l}\text { Leave you to decide } \\
\text { what's best for you } \\
\text { Oppose if choice of major } \\
\text { does not appeal to them }\end{array}$ & 92 & 19.8 & 19.8 & 94.6 \\
& Other & 24 & 5.2 & 5.2 & 99.8 \\
& Total & 1 & .2 & .2 & 100.0 \\
Missing & 9 & 464 & 99.8 & 100.0 & \\
Total & & 465 & 100.0 & & \\
\hline
\end{tabular}

Loans

\begin{tabular}{|ll|r|r|r|r|}
\hline & Frequency & Percent & Valid Percent & $\begin{array}{c}\text { Cumulative } \\
\text { Percent }\end{array}$ \\
\hline Valid & Not at all & 171 & 36.8 & 37.7 & 37.7 \\
& Little & 38 & 8.2 & 8.4 & 46.0 \\
& Somewhat & 61 & 13.1 & 13.4 & 59.5 \\
& Quite a bit & 63 & 13.5 & 13.9 & 73.3 \\
& A great extent & 121 & 26.0 & 26.7 & 100.0 \\
& Total & 454 & 97.6 & 100.0 & \\
Missing & 0 & 11 & 2.4 & & \\
Total & & 465 & 100.0 & & \\
\hline
\end{tabular}

Grants

\begin{tabular}{|ll|r|r|r|r|}
\hline & Frequency & Percent & Valid Percent & $\begin{array}{c}\text { Cumulative } \\
\text { Percent }\end{array}$ \\
\hline Valid & Not at all & 218 & 46.9 & 49.2 & 49.2 \\
& Little & 53 & 11.4 & 12.0 & 61.2 \\
& Somewhat & 48 & 10.3 & 10.8 & 72.0 \\
& Quite a bit & 55 & 11.8 & 12.4 & 84.4 \\
& A great extent & 69 & 14.8 & 15.6 & 100.0 \\
& Total & 443 & 95.3 & 100.0 & \\
Missing & 0 & 22 & 4.7 & & \\
Total & & 465 & 100.0 & & \\
\hline
\end{tabular}




\begin{tabular}{|ll|r|r|r|r|}
\hline & Scholarships \\
\hline Valid & Not at all & 124 & 26.7 & 27.9 & $\begin{array}{c}\text { Cumulative } \\
\text { Percent }\end{array}$ \\
& Little & 75 & 16.1 & 16.9 & 27.9 \\
& Somewhat & 70 & 15.1 & 15.8 & 44.8 \\
& Quite a bit & 56 & 12.0 & 12.6 & 60.6 \\
& A great extent & 119 & 25.6 & 26.8 & 73.2 \\
& Total & 444 & 95.5 & 100.0 & \\
Missing & 0 & 21 & 4.5 & & \\
Total & & 465 & 100.0 & & \\
\hline
\end{tabular}

\begin{tabular}{|ll|r|r|r|r|}
\hline & Srequency & Percent & Valid Percent & $\begin{array}{c}\text { Cumulative } \\
\text { Percent }\end{array}$ \\
\hline Valid & Not at all & 208 & 44.7 & 47.3 & 47.3 \\
& Little & 85 & 18.3 & 19.3 & 66.6 \\
& Somewhat & 69 & 14.8 & 15.7 & 82.3 \\
& Quite a bit & 35 & 7.5 & 8.0 & 90.2 \\
& A great extent & 43 & 9.2 & 9.8 & 100.0 \\
& Total & 440 & 94.6 & 100.0 & \\
Missing & 0 & 25 & 5.4 & & \\
Total & & 465 & 100.0 & & \\
\hline
\end{tabular}

Parents

\begin{tabular}{|ll|r|r|r|r|}
\hline & Frequency & Percent & Valid Percent & $\begin{array}{c}\text { Cumulative } \\
\text { Percent }\end{array}$ \\
\hline Valid & Not at all & 76 & 16.3 & 16.9 & 16.9 \\
& Little & 54 & 11.6 & 12.0 & 28.8 \\
& Somewhat & 74 & 15.9 & 16.4 & 45.2 \\
& Quite a bit & 84 & 18.1 & 18.6 & 63.9 \\
& A great extent & 163 & 35.1 & 36.1 & 100.0 \\
& Total & 451 & 97.0 & 100.0 & \\
Missing & 0 & 14 & 3.0 & & \\
Total & & 465 & 100.0 & & \\
\hline
\end{tabular}


Self

\begin{tabular}{|ll|r|r|r|r|}
\hline & Frequency & Percent & Valid Percent & $\begin{array}{c}\text { Cumulative } \\
\text { Percent }\end{array}$ \\
\hline Valid & Not at all & 3 & .6 & .7 & .7 \\
& Little & 5 & 1.1 & 1.1 & 1.7 \\
& Somewhat & 37 & 8.0 & 8.0 & 9.8 \\
& Quite a bit & 103 & 22.2 & 22.4 & 32.2 \\
& A great extent & 312 & 67.1 & 67.8 & 100.0 \\
& Total & 460 & 98.9 & 100.0 & \\
Missing & 0 & 4 & .9 & & \\
& System & 1 & .2 & & \\
& Total & 5 & 1.1 & & \\
Total & & 465 & 100.0 & & \\
\hline
\end{tabular}

Parents

\begin{tabular}{|ll|r|r|r|r|}
\hline & & Frequency & Percent & Valid Percent & $\begin{array}{c}\text { Cumulative } \\
\text { Percent }\end{array}$ \\
\hline Valid & Not at all & 73 & 15.7 & 15.8 & 15.8 \\
& Little & 87 & 18.7 & 18.8 & 34.6 \\
& Somewhat & 129 & 27.7 & 27.9 & 62.6 \\
& Quite a bit & 104 & 22.4 & 22.5 & 85.1 \\
& A great extent & 69 & 14.8 & 14.9 & 100.0 \\
& Total & 462 & 99.4 & 100.0 & \\
Missing & 0 & 3 & .6 & & \\
Total & & 465 & 100.0 & & \\
\hline
\end{tabular}

High School Counsellor

\begin{tabular}{|ll|r|r|r|r|}
\hline & Frequency & Percent & Valid Percent & $\begin{array}{c}\text { Cumulative } \\
\text { Percent }\end{array}$ \\
\hline Valid & Not at all & 262 & 56.3 & 57.2 & 57.2 \\
& Little & 89 & 19.1 & 19.4 & 76.6 \\
& Somewhat & 66 & 14.2 & 14.4 & 91.0 \\
& Quite a bit & 29 & 6.2 & 6.3 & 97.4 \\
& A great extent & 12 & 2.6 & 2.6 & 100.0 \\
& Total & 458 & 98.5 & 100.0 & \\
Missing & 0 & 7 & 1.5 & & \\
Total & & 465 & 100.0 & & \\
\hline
\end{tabular}




\begin{tabular}{|ll|r|r|r|r|}
\hline \multicolumn{1}{|c|}{ Peers } \\
& Frequency & Percent & Valid Percent & $\begin{array}{c}\text { Cumulative } \\
\text { Percent }\end{array}$ \\
\hline Valid & Not at all & 111 & 23.9 & 24.1 & 24.1 \\
& Little & 78 & 16.8 & 16.9 & 41.0 \\
& Somewhat & 107 & 23.0 & 23.2 & 64.2 \\
& Quite a bit & 105 & 22.6 & 22.8 & 87.0 \\
& A great extent & 60 & 12.9 & 13.0 & 100.0 \\
& Total & 461 & 99.1 & 100.0 & \\
Missing & 0 & 4 & .9 & & \\
\hline
\end{tabular}

\begin{tabular}{|ll|r|r|r|r|}
\hline & Cost of Tuition \\
\hline Valid & Not at all & 142 & 30.5 & 30.9 & $\begin{array}{c}\text { Cumulative } \\
\text { Percent }\end{array}$ \\
& Little & 69 & 14.8 & 15.0 & 30.9 \\
& Somewhat & 99 & 21.3 & 21.6 & 46.0 \\
& Quite a bit & 74 & 15.9 & 16.1 & 67.5 \\
& A great extent & 75 & 16.1 & 16.3 & 83.7 \\
& Total & 459 & 98.7 & 100.0 & \\
Missing & 0 & 6 & 1.3 & & \\
Total & & 465 & 100.0 & & \\
\hline
\end{tabular}

Appeal of the City of Morgantown

\begin{tabular}{|ll|r|r|r|r|}
\hline & & Frequency & Percent & Valid Percent & $\begin{array}{c}\text { Cumulative } \\
\text { Percent }\end{array}$ \\
\hline Valid & Not at all & 95 & 20.4 & 20.6 & 20.6 \\
& Little & 79 & 17.0 & 17.1 & 37.7 \\
& Somewhat & 111 & 23.9 & 24.0 & 61.7 \\
& Quite a bit & 106 & 22.8 & 22.9 & 84.6 \\
& A great extent & 71 & 15.3 & 15.4 & 100.0 \\
& Total & 462 & 99.4 & 100.0 & \\
Missing & 0 & 3 & .6 & & \\
Total & & 465 & 100.0 & & \\
\hline
\end{tabular}


College Recruiters

\begin{tabular}{|ll|r|r|r|r|}
\hline & Frequency & Percent & Valid Percent & $\begin{array}{c}\text { Cumulative } \\
\text { Percent }\end{array}$ \\
\hline Valid & Not at all & 299 & 64.3 & 65.4 & 65.4 \\
& Little & 86 & 18.5 & 18.8 & 84.2 \\
& Somewhat & 35 & 7.5 & 7.7 & 91.9 \\
& Quite a bit & 18 & 3.9 & 3.9 & 95.8 \\
& A great extent & 19 & 4.1 & 4.2 & 100.0 \\
& Total & 457 & 98.3 & 100.0 & \\
Missing & 0 & 7 & 1.5 & & \\
& System & 1 & .2 & & \\
& Total & 8 & 1.7 & & \\
\hline \multirow{7}{*}{ Total } & & 465 & 100.0 & & \\
\hline
\end{tabular}

Other

\begin{tabular}{|ll|r|r|r|r|}
\hline & & Frequency & Percent & Valid Percent & $\begin{array}{c}\text { Cumulative } \\
\text { Percent }\end{array}$ \\
\hline Valid & Not at all & 238 & 51.2 & 57.5 & 57.5 \\
& Little & 27 & 5.8 & 6.5 & 64.0 \\
& Somewhat & 50 & 10.8 & 12.1 & 76.1 \\
& Quite a bit & 32 & 6.9 & 7.7 & 83.8 \\
& A great extent & 67 & 14.4 & 16.2 & 100.0 \\
& Total & 414 & 89.0 & 100.0 & \\
Missing & 0 & 51 & 11.0 & & \\
Total & & 465 & 100.0 & & \\
\hline
\end{tabular}

\begin{tabular}{|ll|r|r|r|r|}
\hline \multicolumn{1}{|c|}{ Passion for Disicpline } \\
\hline Valid & Frequency & Percent & Valid Percent & $\begin{array}{c}\text { Cumulative } \\
\text { Percent }\end{array}$ \\
& Little & 46 & 9.9 & 10.0 & 10.0 \\
& Somewhat & 33 & 7.1 & 7.2 & 17.1 \\
& Quite a bit & 96 & 20.6 & 20.8 & 38.0 \\
& A great extent & 135 & 29.0 & 29.3 & 67.2 \\
& Total & 151 & 32.5 & 32.8 & 100.0 \\
Missing & 0 & 461 & 99.1 & 100.0 & \\
Total & 4 & .9 & & \\
\hline
\end{tabular}


Peer Influence

\begin{tabular}{|ll|r|r|r|r|}
\hline & Frequency & Percent & Valid Percent & $\begin{array}{c}\text { Cumulative } \\
\text { Percent }\end{array}$ \\
\hline Valid & Not at all & 179 & 38.5 & 38.9 & 38.9 \\
& Little & 134 & 28.8 & 29.1 & 68.0 \\
& Somewhat & 98 & 21.1 & 21.3 & 89.3 \\
& Quite a bit & 37 & 8.0 & 8.0 & 97.4 \\
& A great extent & 12 & 2.6 & 2.6 & 100.0 \\
& Total & 460 & 98.9 & 100.0 & \\
Missing & 0 & 5 & 1.1 & & \\
Total & & 465 & 100.0 & & \\
\hline
\end{tabular}

Financial Reward in the future

\begin{tabular}{|ll|r|r|r|r|}
\hline & Frequency & Percent & Valid Percent & $\begin{array}{c}\text { Cumulative } \\
\text { Percent }\end{array}$ \\
\hline Valid & Not at all & 61 & 13.1 & 13.4 & 13.4 \\
& Little & 63 & 13.5 & 13.8 & 27.2 \\
& Somewhat & 99 & 21.3 & 21.7 & 48.9 \\
& Quite a bit & 135 & 29.0 & 29.6 & 78.5 \\
& A great extent & 98 & 21.1 & 21.5 & 100.0 \\
& Total & 456 & 98.1 & 100.0 & \\
Missing & 0 & 8 & 1.7 & & \\
& System & 1 & .2 & & \\
& Total & 9 & 1.9 & & \\
Total & & 465 & 100.0 & & \\
\hline
\end{tabular}

Academic Advisor

\begin{tabular}{|ll|r|r|r|r|}
\hline & Frequency & Percent & Valid Percent & $\begin{array}{c}\text { Cumulative } \\
\text { Percent }\end{array}$ \\
\hline Valid & Not at all & 213 & 45.8 & 46.4 & 46.4 \\
& Little & 114 & 24.5 & 24.8 & 71.2 \\
& Somewhat & 84 & 18.1 & 18.3 & 89.5 \\
& Quite a bit & 32 & 6.9 & 7.0 & 96.5 \\
& A great extent & 16 & 3.4 & 3.5 & 100.0 \\
& Total & 459 & 98.7 & 100.0 & \\
Missing & 0 & 6 & 1.3 & & \\
Total & & 465 & 100.0 & & \\
\hline
\end{tabular}


Meeting family obligations

\begin{tabular}{|ll|r|r|r|r|}
\hline & Frequency & Percent & Valid Percent & $\begin{array}{c}\text { Cumulative } \\
\text { Percent }\end{array}$ \\
\hline Valid & Not at all & 217 & 46.7 & 47.4 & 47.4 \\
& Little & 104 & 22.4 & 22.7 & 70.1 \\
& Somewhat & 76 & 16.3 & 16.6 & 86.7 \\
& Quite a bit & 43 & 9.2 & 9.4 & 96.1 \\
& A great extent & 18 & 3.9 & 3.9 & 100.0 \\
& Total & 458 & 98.5 & 100.0 & \\
Missing & 0 & 7 & 1.5 & & \\
Total & & 465 & 100.0 & & \\
\hline
\end{tabular}

GPA requirements for major

\begin{tabular}{|ll|r|r|r|r|}
\hline & Frequency & Percent & Valid Percent & $\begin{array}{c}\text { Cumulative } \\
\text { Percent }\end{array}$ \\
\hline Valid & Not at all & 186 & 40.0 & 40.7 & 40.7 \\
& Little & 92 & 19.8 & 20.1 & 60.8 \\
& Somewhat & 98 & 21.1 & 21.4 & 82.3 \\
& Quite a bit & 57 & 12.3 & 12.5 & 94.7 \\
& A great extent & 24 & 5.2 & 5.3 & 100.0 \\
& Total & 457 & 98.3 & 100.0 & \\
Missing & 0 & 8 & 1.7 & & \\
Total & & 465 & 100.0 & & \\
\hline
\end{tabular}

College major entry requirements

\begin{tabular}{|ll|r|r|r|r|}
\hline & Frequency & Percent & Valid Percent & $\begin{array}{c}\text { Cumulative } \\
\text { Percent }\end{array}$ \\
\hline Valid & Not at all & 177 & 38.1 & 38.7 & 38.7 \\
& Little & 96 & 20.6 & 21.0 & 59.7 \\
& Somewhat & 90 & 19.4 & 19.7 & 79.4 \\
& Quite a bit & 69 & 14.8 & 15.1 & 94.5 \\
& A great extent & 25 & 5.4 & 5.5 & 100.0 \\
& Total & 457 & 98.3 & 100.0 & \\
Missing & 0 & 8 & 1.7 & & \\
Total & & 465 & 100.0 & & \\
\hline
\end{tabular}


College experience of family and friends

\begin{tabular}{|ll|r|r|r|r|}
\hline & & Frequency & Percent & Valid Percent & $\begin{array}{c}\text { Cumulative } \\
\text { Percent }\end{array}$ \\
\hline Valid & Not at all & 90 & 19.4 & 19.6 & 19.6 \\
& Little & 83 & 17.8 & 18.0 & 37.6 \\
& Somewhat & 126 & 27.1 & 27.4 & 65.0 \\
& Quite a bit & 92 & 19.8 & 20.0 & 85.0 \\
& A great extent & 69 & 14.8 & 15.0 & 100.0 \\
& Total & 460 & 98.9 & 100.0 & \\
Missing & 0 & 5 & 1.1 & & \\
Total & & 465 & 100.0 & & \\
\hline
\end{tabular}

Popularity of major in media

\begin{tabular}{|ll|r|r|r|r|}
\hline & & Frequency & Percent & Valid Percent & $\begin{array}{c}\text { Cumulative } \\
\text { Percent }\end{array}$ \\
\hline Valid & Not at all & 126 & 27.1 & 27.5 & 27.5 \\
& Little & 107 & 23.0 & 23.3 & 50.8 \\
& Somewhat & 113 & 24.3 & 24.6 & 75.4 \\
& Quite a bit & 88 & 18.9 & 19.2 & 94.6 \\
& A great extent & 25 & 5.4 & 5.4 & 100.0 \\
& Total & 459 & 98.7 & 100.0 & \\
Missing & 0 & 4 & .9 & & \\
& System & 2 & .4 & & \\
& Total & 6 & 1.3 & & \\
Total & & 465 & 100.0 & & \\
\hline
\end{tabular}

Prospects of advancement in the job market

\begin{tabular}{|ll|r|r|r|r|}
\hline & & Frequency & Percent & Valid Percent & $\begin{array}{c}\text { Cumulative } \\
\text { Percent }\end{array}$ \\
\hline Valid & Not at all & 52 & 11.2 & 11.3 & 11.3 \\
& Little & 39 & 8.4 & 8.4 & 19.7 \\
& Somewhat & 108 & 23.2 & 23.4 & 43.1 \\
& Quite a bit & 163 & 35.1 & 35.3 & 78.4 \\
& A great extent & 100 & 21.5 & 21.6 & 100.0 \\
& Total & 462 & 99.4 & 100.0 & \\
Missing & 0 & 3 & .6 & & \\
Total & & 465 & 100.0 & & \\
\hline
\end{tabular}


Sucess of Family in friends with similar degrees

\begin{tabular}{|ll|r|r|r|r|}
\hline & Frequency & Percent & Valid Percent & $\begin{array}{c}\text { Cumulative } \\
\text { Percent }\end{array}$ \\
\hline Valid & Not at all & 146 & 31.4 & 31.9 & 31.9 \\
& Little & 77 & 16.6 & 16.8 & 48.7 \\
& Somewhat & 85 & 18.3 & 18.6 & 67.2 \\
& Quite a bit & 90 & 19.4 & 19.7 & 86.9 \\
& A great extent & 60 & 12.9 & 13.1 & 100.0 \\
& Total & 458 & 98.5 & 100.0 & \\
Missing & 0 & 7 & 1.5 & & \\
Total & & 465 & 100.0 & & \\
\hline
\end{tabular}

Job Security

\begin{tabular}{|ll|r|r|r|r|}
\hline & Frequency & Percent & Valid Percent & $\begin{array}{c}\text { Cumulative } \\
\text { Percent }\end{array}$ \\
\hline Valid & Not at all & 54 & 11.6 & 11.7 & 11.7 \\
& Little & 64 & 13.8 & 13.9 & 25.7 \\
& Somewhat & 96 & 20.6 & 20.9 & 46.5 \\
& Quite a bit & 138 & 29.7 & 30.0 & 76.5 \\
& A great extent & 108 & 23.2 & 23.5 & 100.0 \\
& Total & 460 & 98.9 & 100.0 & \\
Missing & 0 & 5 & 1.1 & & \\
Total & & 465 & 100.0 & & \\
\hline
\end{tabular}

Passion for discipline

\begin{tabular}{|ll|r|r|r|r|}
\hline & Frequency & Percent & Valid Percent & $\begin{array}{c}\text { Cumulative } \\
\text { Percent }\end{array}$ \\
\hline Valid & Not at all & 40 & 8.6 & 8.7 & 8.7 \\
& Little & 51 & 11.0 & 11.1 & 19.8 \\
& Somewhat & 85 & 18.3 & 18.5 & 38.3 \\
& Quite a bit & 130 & 28.0 & 28.3 & 66.7 \\
& A great extent & 153 & 32.9 & 33.3 & 100.0 \\
& Total & 459 & 98.7 & 100.0 & \\
Missing & 0 & 6 & 1.3 & & \\
Total & & 465 & 100.0 & & \\
\hline
\end{tabular}


Availability of funds

\begin{tabular}{|ll|r|r|r|r|}
\hline & Frequency & Percent & Valid Percent & $\begin{array}{c}\text { Cumulative } \\
\text { Percent }\end{array}$ \\
\hline Valid & Not at all & 129 & 27.7 & 28.1 & 28.1 \\
& Little & 73 & 15.7 & 15.9 & 44.0 \\
& Somewhat & 120 & 25.8 & 26.1 & 70.2 \\
& Quite a bit & 93 & 20.0 & 20.3 & 90.4 \\
& A great extent & 44 & 9.5 & 9.6 & 100.0 \\
& Total & 459 & 98.7 & 100.0 & \\
Missing & 0 & 6 & 1.3 & & \\
Total & & 465 & 100.0 & & \\
\hline
\end{tabular}

Meeting departmental requirements

\begin{tabular}{|ll|r|r|r|r|}
\hline & & Frequency & Percent & Valid Percent & $\begin{array}{c}\text { Cumulative } \\
\text { Percent }\end{array}$ \\
\hline Valid & Not at all & 78 & 16.8 & 17.0 & 17.0 \\
& Little & 89 & 19.1 & 19.4 & 36.4 \\
& Somewhat & 102 & 21.9 & 22.2 & 58.6 \\
& Quite a bit & 118 & 25.4 & 25.7 & 84.3 \\
& A great extent & 72 & 15.5 & 15.7 & 100.0 \\
& Total & 459 & 98.7 & 100.0 & \\
Missing & 0 & 6 & 1.3 & & \\
Total & & 465 & 100.0 & & \\
\hline
\end{tabular}

Staying on Track

\begin{tabular}{|ll|r|r|r|r|}
\hline & Frequency & Percent & Valid Percent & $\begin{array}{c}\text { Cumulative } \\
\text { Percent }\end{array}$ \\
\hline Valid & Not at all & 70 & 15.1 & 15.2 & 15.2 \\
& Little & 74 & 15.9 & 16.1 & 31.3 \\
& Somewhat & 104 & 22.4 & 22.6 & 53.9 \\
& Quite a bit & 130 & 28.0 & 28.3 & 82.2 \\
& A great extent & 82 & 17.6 & 17.8 & 100.0 \\
& Total & 460 & 98.9 & 100.0 & \\
Missing & 0 & 5 & 1.1 & & \\
Total & & 465 & 100.0 & & \\
\hline
\end{tabular}


Other

\begin{tabular}{|ll|r|r|r|r|}
\hline & & Frequency & Percent & Valid Percent & $\begin{array}{c}\text { Cumulative } \\
\text { Percent }\end{array}$ \\
\hline Valid & Not at all & 262 & 56.3 & 69.1 & 69.1 \\
& Little & 51 & 11.0 & 13.5 & 82.6 \\
& Somewhat & 33 & 7.1 & 8.7 & 91.3 \\
& Quite a bit & 17 & 3.7 & 4.5 & 95.8 \\
& A great extent & 16 & 3.4 & 4.2 & 100.0 \\
& Total & 379 & 81.5 & 100.0 & \\
Missing & 0 & 85 & 18.3 & & \\
& System & 1 & .2 & & \\
& Total & 86 & 18.5 & & \\
Total & 465 & 100.0 & & \\
\hline
\end{tabular}

Arriving at major choice through personal research

\begin{tabular}{|ll|r|r|r|r|}
\hline & & Frequency & Percent & Valid Percent & $\begin{array}{c}\text { Cumulative } \\
\text { Percent }\end{array}$ \\
\hline Valid & Never & 16 & 3.4 & 3.5 & 3.5 \\
& Little & 41 & 8.8 & 9.0 & 12.5 \\
& Somewhat & 110 & 23.7 & 24.1 & 36.6 \\
& Much & 163 & 35.1 & 35.7 & 72.4 \\
& A great extent & 126 & 27.1 & 27.6 & 100.0 \\
& Total & 456 & 98.1 & 100.0 & \\
Missing & 0 & 9 & 1.9 & & \\
Total & & 465 & 100.0 & & \\
\hline
\end{tabular}

Influence from peers

\begin{tabular}{|ll|r|r|r|r|}
\hline & Frequency & Percent & Valid Percent & $\begin{array}{c}\text { Cumulative } \\
\text { Percent }\end{array}$ \\
\hline Valid & Never & 135 & 29.0 & 29.7 & 29.7 \\
& Little & 148 & 31.8 & 32.5 & 62.2 \\
& Somewhat & 117 & 25.2 & 25.7 & 87.9 \\
& Much & 45 & 9.7 & 9.9 & 97.8 \\
& A great extent & 10 & 2.2 & 2.2 & 100.0 \\
& Total & 455 & 97.8 & 100.0 & \\
Missing & 0 & 9 & 1.9 & & \\
& System & 1 & .2 & & \\
& Total & 10 & 2.2 & & \\
Total & & 465 & 100.0 & & \\
\hline
\end{tabular}


Suggestions from parents or siblings

\begin{tabular}{|ll|r|r|r|r|}
\hline & & Frequency & Percent & Valid Percent & $\begin{array}{c}\text { Cumulative } \\
\text { Percent }\end{array}$ \\
\hline Valid & Never & 76 & 16.3 & 16.8 & 16.8 \\
& Little & 98 & 21.1 & 21.6 & 38.4 \\
& Somewhat & 143 & 30.8 & 31.6 & 70.0 \\
& Much & 107 & 23.0 & 23.6 & 93.6 \\
& A great extent & 29 & 6.2 & 6.4 & 100.0 \\
& Total & 453 & 97.4 & 100.0 & \\
Missing & 0 & 10 & 2.2 & & \\
& System & 2 & .4 & & \\
& Total & 12 & 2.6 & & \\
Total & & 465 & 100.0 & & \\
\hline
\end{tabular}

Living testimony of job prospects from someone you know

\begin{tabular}{|ll|r|r|r|r|}
\hline & Frequency & Percent & Valid Percent & $\begin{array}{c}\text { Cumulative } \\
\text { Percent }\end{array}$ \\
\hline Valid & Never & 56 & 12.0 & 12.3 & 12.3 \\
& Little & 61 & 13.1 & 13.4 & 25.8 \\
& Somewhat & 103 & 22.2 & 22.7 & 48.5 \\
& Much & 136 & 29.2 & 30.0 & 78.4 \\
& A great extent & 98 & 21.1 & 21.6 & 100.0 \\
& Total & 454 & 97.6 & 100.0 & \\
Missing & 0 & 10 & 2.2 & & \\
& System & 1 & .2 & & \\
& Total & 11 & 2.4 & & \\
Total & & 465 & 100.0 & & \\
\hline
\end{tabular}

Research into short term and long term benefits of major

\begin{tabular}{|ll|r|r|r|r|}
\hline & Frequency & Percent & Valid Percent & $\begin{array}{c}\text { Cumulative } \\
\text { Percent }\end{array}$ \\
\hline Valid & Never & 30 & 6.5 & 6.6 & 6.6 \\
& Little & 61 & 13.1 & 13.4 & 20.0 \\
& Somewhat & 120 & 25.8 & 26.3 & 46.3 \\
& Much & 149 & 32.0 & 32.7 & 78.9 \\
& A great extent & 96 & 20.6 & 21.1 & 100.0 \\
& Total & 456 & 98.1 & 100.0 & \\
Missing & 0 & 9 & 1.9 & & \\
Total & & 465 & 100.0 & & \\
\hline
\end{tabular}




\begin{tabular}{|ll|r|r|r|r|}
\hline & Mentorship from Academic Advisor \\
\hline & Frequency & Percent & Valid Percent & $\begin{array}{c}\text { Cumulative } \\
\text { Percent }\end{array}$ \\
\hline Valid & Never & 197 & 42.4 & 43.3 & 43.3 \\
& Little & 113 & 24.3 & 24.8 & 68.1 \\
& Somewhat & 96 & 20.6 & 21.1 & 89.2 \\
& Much & 36 & 7.7 & 7.9 & 97.1 \\
& A great extent & 13 & 2.8 & 2.9 & 100.0 \\
& Total & 455 & 97.8 & 100.0 & \\
Missing & 0 & 10 & 2.2 & & \\
Total & & 465 & 100.0 & & \\
\hline
\end{tabular}

Course requirements for intended major

\begin{tabular}{|ll|r|r|r|r|}
\hline & Frequency & Percent & Valid Percent & $\begin{array}{c}\text { Cumulative } \\
\text { Percent }\end{array}$ \\
\hline Valid & Never & 107 & 23.0 & 23.6 & 23.6 \\
& Little & 87 & 18.7 & 19.2 & 42.7 \\
& Somewhat & 149 & 32.0 & 32.8 & 75.6 \\
& Much & 83 & 17.8 & 18.3 & 93.8 \\
& A great extent & 28 & 6.0 & 6.2 & 100.0 \\
& Total & 454 & 97.6 & 100.0 & \\
Missing & 0 & 11 & 2.4 & & \\
Total & & 465 & 100.0 & & \\
\hline
\end{tabular}

\section{Passion for major}

\begin{tabular}{|ll|r|r|r|r|}
\hline & & Frequency & Percent & Valid Percent & $\begin{array}{c}\text { Cumulative } \\
\text { Percent }\end{array}$ \\
\hline Valid & Never & 17 & 3.7 & 3.7 & 3.7 \\
& Little & 23 & 4.9 & 5.0 & 8.8 \\
& Somewhat & 72 & 15.5 & 15.8 & 24.5 \\
& Much & 138 & 29.7 & 30.2 & 54.7 \\
& A great extent & 207 & 44.5 & 45.3 & 100.0 \\
& Total & 457 & 98.3 & 100.0 & \\
Missing & 0 & 8 & 1.7 & & \\
Total & & 465 & 100.0 & & \\
\hline
\end{tabular}


Nature of work environment

\begin{tabular}{|ll|r|r|r|r|}
\hline & & Frequency & Percent & Valid Percent & $\begin{array}{c}\text { Cumulative } \\
\text { Percent }\end{array}$ \\
\hline Valid & Never & 19 & 4.1 & 4.2 & 4.2 \\
& Little & 16 & 3.4 & 3.5 & 7.7 \\
& Somewhat & 70 & 15.1 & 15.4 & 23.0 \\
& Much & 160 & 34.4 & 35.1 & 58.1 \\
& A great extent & 191 & 41.1 & 41.9 & 100.0 \\
& Total & 456 & 98.1 & 100.0 & \\
Missing & 0 & 9 & 1.9 & & \\
Total & & 465 & 100.0 & & \\
\hline
\end{tabular}

Involvement of family and peers

\begin{tabular}{|ll|r|r|r|r|}
\hline & & Frequency & Percent & Valid Percent & $\begin{array}{c}\text { Cumulative } \\
\text { Percent }\end{array}$ \\
\hline Valid & Yes & 421 & 90.5 & 91.9 & 91.9 \\
& No & 37 & 8.0 & 8.1 & 100.0 \\
& Total & 458 & 98.5 & 100.0 & \\
Missing & 9 & 7 & 1.5 & & \\
Total & & 465 & 100.0 & & \\
\hline
\end{tabular}

Impact of pre- college education, family and friends on current college career

\begin{tabular}{|ll|r|r|r|r|}
\hline & & Frequency & Percent & Valid Percent & $\begin{array}{c}\text { Cumulative } \\
\text { Percent }\end{array}$ \\
\hline Valid & Yes & 375 & 80.6 & 81.9 & 81.9 \\
& No & 83 & 17.8 & 18.1 & 100.0 \\
& Total & 458 & 98.5 & 100.0 & \\
Missing & 9 & 7 & 1.5 & & \\
Total & & 465 & 100.0 & & \\
\hline
\end{tabular}

Ability to control major entry requirements

\begin{tabular}{|ll|r|r|r|r|}
\hline & & Frequency & Percent & Valid Percent & $\begin{array}{c}\text { Cumulative } \\
\text { Percent }\end{array}$ \\
\hline Valid & Yes & 374 & 80.4 & 81.7 & 81.7 \\
& No & 84 & 18.1 & 18.3 & 100.0 \\
& Total & 458 & 98.5 & 100.0 & \\
Missing & 9 & 7 & 1.5 & & \\
Total & & 465 & 100.0 & & \\
\hline
\end{tabular}


Impact of tuition cost on major choice

\begin{tabular}{|ll|r|r|r|r|}
\hline & & Frequency & Percent & Valid Percent & $\begin{array}{c}\text { Cumulative } \\
\text { Percent }\end{array}$ \\
\hline Valid & Yes & 142 & 30.5 & 30.9 & 30.9 \\
& No & 317 & 68.2 & 69.1 & 100.0 \\
& Total & 459 & 98.7 & 100.0 & \\
Missing & 9 & 6 & 1.3 & & \\
Total & & 465 & 100.0 & & \\
\hline
\end{tabular}

Impact of scholarships on major choice

\begin{tabular}{|ll|r|r|r|r|}
\hline & & Frequency & Percent & Valid Percent & $\begin{array}{c}\text { Cumulative } \\
\text { Percent }\end{array}$ \\
\hline Valid & Yes & 185 & 39.8 & 40.2 & 40.2 \\
& No & 275 & 59.1 & 59.8 & 100.0 \\
& Total & 460 & 98.9 & 100.0 & \\
Missing & 9 & 5 & 1.1 & & \\
Total & & 465 & 100.0 & & \\
\hline
\end{tabular}

Effect of future renumeration on major choice

\begin{tabular}{|ll|r|r|r|r|}
\hline & & Frequency & Percent & Valid Percent & $\begin{array}{c}\text { Cumulative } \\
\text { Percent }\end{array}$ \\
\hline Valid & Yes & 372 & 80.0 & 80.9 & 80.9 \\
& No & 88 & 18.9 & 19.1 & 100.0 \\
& Total & 460 & 98.9 & 100.0 & \\
Missing & 9 & 5 & 1.1 & & \\
Total & & 465 & 100.0 & & \\
\hline
\end{tabular}

Effect of Loan pay back obligations on major choice

\begin{tabular}{|ll|r|r|r|r|}
\hline & & Frequency & Percent & Valid Percent & $\begin{array}{c}\text { Cumulative } \\
\text { Percent }\end{array}$ \\
\hline Valid & Yes & 125 & 26.9 & 27.2 & 27.2 \\
& No & 334 & 71.8 & 72.8 & 100.0 \\
& Total & 459 & 98.7 & 100.0 & \\
Missing & 9 & 6 & 1.3 & & \\
Total & & 465 & 100.0 & & \\
\hline
\end{tabular}


Opportunity to design own major

\begin{tabular}{|ll|r|r|r|r|}
\hline & & Frequency & Percent & Valid Percent & $\begin{array}{c}\text { Cumulative } \\
\text { Percent }\end{array}$ \\
\hline Valid & Yes & 384 & 82.6 & 83.5 & 83.5 \\
& No & 76 & 16.3 & 16.5 & 100.0 \\
& Total & 460 & 98.9 & 100.0 & \\
Missing & 9 & 5 & 1.1 & & \\
Total & & 465 & 100.0 & & \\
\hline
\end{tabular}

Ethnicity Collapsed

\begin{tabular}{|ll|r|r|r|r|}
\hline & & Frequency & Percent & Valid Percent & $\begin{array}{c}\text { Cumulative } \\
\text { Percent }\end{array}$ \\
\hline Valid & Caucasian & 410 & 88.2 & 89.3 & 89.3 \\
& Other & 49 & 10.5 & 10.7 & 100.0 \\
& Total & 459 & 98.7 & 100.0 & \\
Missing & 7 & 6 & 1.3 & & \\
Total & 465 & 100.0 & & \\
\hline
\end{tabular}

Admission Status Collapsed

\begin{tabular}{|ll|r|r|r|r|}
\hline & & Frequency & Percent & Valid Percent & $\begin{array}{c}\text { Cumulative } \\
\text { Percent }\end{array}$ \\
\hline Valid & In State & 211 & 45.4 & 45.6 & 45.6 \\
& Out of State & 244 & 52.5 & 52.7 & 98.3 \\
& Other & 8 & 1.7 & 1.7 & 100.0 \\
& Total & 463 & 99.6 & 100.0 & \\
Missing & System & 2 & .4 & & \\
Total & & 465 & 100.0 & & \\
\hline
\end{tabular}

Major Collapsed

\begin{tabular}{|ll|r|r|r|r|}
\hline & Frequency & Percent & Valid Percent & $\begin{array}{c}\text { Cumulative } \\
\text { Percent }\end{array}$ \\
\hline Valid & Pre - Business & 85 & 18.3 & 18.3 & 18.3 \\
& Pre - Criminology & 36 & 7.7 & 7.7 & 26.0 \\
Pre - Biology & 30 & 6.5 & 6.5 & 32.5 \\
Pre - Nursing & 28 & 6.0 & 6.0 & 38.5 \\
Pre - Engineering & 29 & 6.2 & 6.2 & 44.7 \\
Pre - Journalism & 34 & 7.3 & 7.3 & 52.0 \\
Pre - Pharmacy & 16 & 3.4 & 3.4 & 55.5 \\
General Studies Eduction & 20 & 4.3 & 4.3 & 59.8 \\
Other & 187 & 40.2 & 40.2 & 100.0 \\
Total & 465 & 100.0 & 100.0 & \\
\hline
\end{tabular}


Academic Classification

\begin{tabular}{|ll|r|r|r|r|}
\hline & & Frequency & Percent & Valid Percent & $\begin{array}{c}\text { Cumulative } \\
\text { Percent }\end{array}$ \\
\hline Valid & Freshmen & 309 & 66.5 & 66.7 & 66.7 \\
& Sophomores & 154 & 33.1 & 33.3 & 100.0 \\
& Total & 463 & 99.6 & 100.0 & \\
Missing & 5 & 2 & .4 & & \\
Total & & 465 & 100.0 & & \\
\hline
\end{tabular}

\footnotetext{
John $\mathrm{H}$. 